Historic, Archive Document

Do not assume content reflects current scientific knowledge, policies, or practices. 



\section{HARRIS' SEEDS}

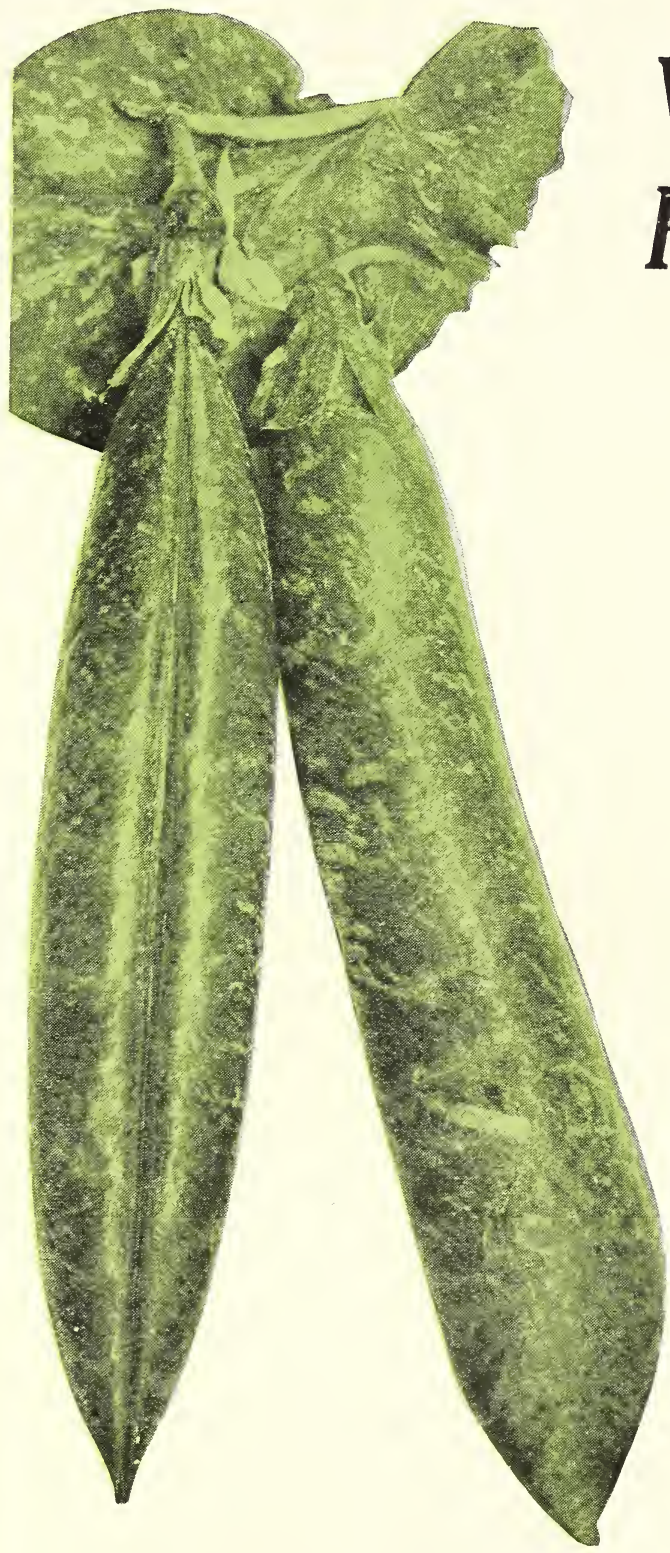

Wholesale

Price List

For

Market

Gardeners

and

Florists

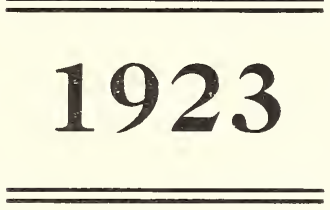

New Early Pea-Acquisition

\section{Joseph Harris Co. SEED GROWERS}

Moreton Farm COLDWATER, N. Y. 


\section{About Orders, Shipping, Etc.}

The prices quoted in this list do not include cost of delivery, which must be paid by the purchaser. We make no charge for bags, boxes, or packing.

\section{Parcel Post}

Parcel post rates are very low to places within 150 miles of Rochester. Only 1e per pound after the first pound which is je.

The following tables give the rates to different parts of the country:

\begin{tabular}{|c|c|c|c|c|c|c|}
\hline & Addit & $\begin{array}{l}\text { Each } \\
\text { ional }\end{array}$ & & Add & & $\begin{array}{l}\text { Cach } \\
\text { onal }\end{array}$ \\
\hline & $1 \mathrm{lb}$. & lb. & & $1 \mathrm{lb}$. & & \\
\hline$\ldots \ldots \$$ & $.08 \$$ & .06 & Montana & .11 & $\$$ & .10 \\
\hline kansas & .08 & .06 & Nebraska & .09 & & .08 \\
\hline lifornia & 12 & .12 & Nevada. & .12 & & .12 \\
\hline lorado & .11 & .10 & New Jersey & .06 & & .04 \\
\hline nn., Western half & .06 & .02 & N. Hampshire, Eastern half & .07 & & .04 \\
\hline nn., Eastern half & .07 & .04 & N. Hampshire, Western half & .06 & & .02 \\
\hline laware $\ldots \ldots \ldots \ldots \ldots$ & .07 & .04 & New York, Western half . & .05 & & .01 \\
\hline$\ldots \ldots \ldots \ldots \ldots \ldots$ & .09 & .08 & New York, Eastern half .... & .06 & & .02 \\
\hline orgia & .08 & .06 & North Carolina & .07 & & .04 \\
\hline 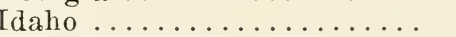 & .12 & .12 & North Dakota & .09 & & .08 \\
\hline nois, Eastern half & .07 & .04 & Ohio, Eastern half & .06 & & .02 \\
\hline inois, Western half ..... & .08 & .06 & Ohio, Western half & .07 & & .04 \\
\hline diana $\ldots \ldots \ldots \ldots \ldots$ & .07 & .04 & 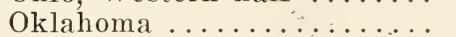 & .09 & & .08 \\
\hline . & .08 & .06 & Ore & .12 & & .12 \\
\hline . & .09 & .08 & Rhode Island & .07 & & .04 \\
\hline $\mathrm{ky}$, Eastern half & .07 & .04 & South Carolina. & .08 & & .06 \\
\hline cky, Western half & .08 & .06 & South Dakota.. & .08 & & .08 \\
\hline disiana... & .09 & .08 & Tennesee & .08 & & .06 \\
\hline$\ldots$ & .07 & .04 & part & .09 & & .08 \\
\hline ss., Eastern half & .07 & .04 & Texas, Western part ....... & .11 & & .10 \\
\hline Western half & .06 & .02 & Vermont .... & .06 & & .02 \\
\hline land, No. of Baltimore. & .07 & .04 & Virginia & .07 & & .04 \\
\hline and, So. of Baltimore & .08 & .06 & Washington & .12 & & .12 \\
\hline$\ldots \ldots \ldots \ldots \ldots$ & .07 & .04 & Wisconsin, Eastern half & .07 & & .04 \\
\hline & .08 & .06 & Wisconsin, Western half ... & .08 & & .06 \\
\hline & .08 & .06 & Wroming $\ldots \ldots \ldots \ldots \ldots$ & .11 & & .10 \\
\hline $\mathrm{pr}$ & .08 & .06 & & & & \\
\hline
\end{tabular}

When ordering seeds sent by parcel post please add enough money to the price to cover the necessary postage which we shall have to pay.

BY EXPRESS. The express rates are now a little lower than parcel post on all lots weighing 50 pounds or more. On smaller packages parcel post is cheaper. Express eharges need not be prepaid, but parcel post must be.

BY FREIGHT. .Lots weighing over 100 pounds will go cheaper by freight than by express, but it takes longer for freight to get through. If seeds are wanted immediately and you are willing to pay the extra cost it is best to have them sent by express.

Please state on your order whether you wish the seeds sent by parcel post, express, or freight. If ordered by parcel post please add to the amount remitted enough to pay postage.

CONDITIONS OF SALE. We agree to assume the responsibility of the seeds and plants we sell reaching the purchaser in good condition, and should any seeds fail to grow under favorable conditions, or prove not true to name or of inferior quality, we will REFUND THE MONEY PAID FOR THEM or replace them without charge, but all our seeds and plants are sold on the distinct understanding and with the agreement by the purchaser that we will not be liable for any loss or damage that may occur by reason of the failure of seeds or plants to grow or to be of the variety or quality offered. We will not accept or fill orders on any other terms.

JOSEPH HARRIS CO.

TERMS. Our regular terms are eash with order, less a discount of 2 per cent, except Grass seeds, Potatoes and Onion sets, on which no discount can be allowed. We should, however, be glad to open accounts with any gardeners of established eredit, or who will furnish us satisfactory references. On such accounts all bills are due September 1, with no discount.

JOSEPH HARRIS CO.,

December 1, 1922.

Coldwater, N. Y. 


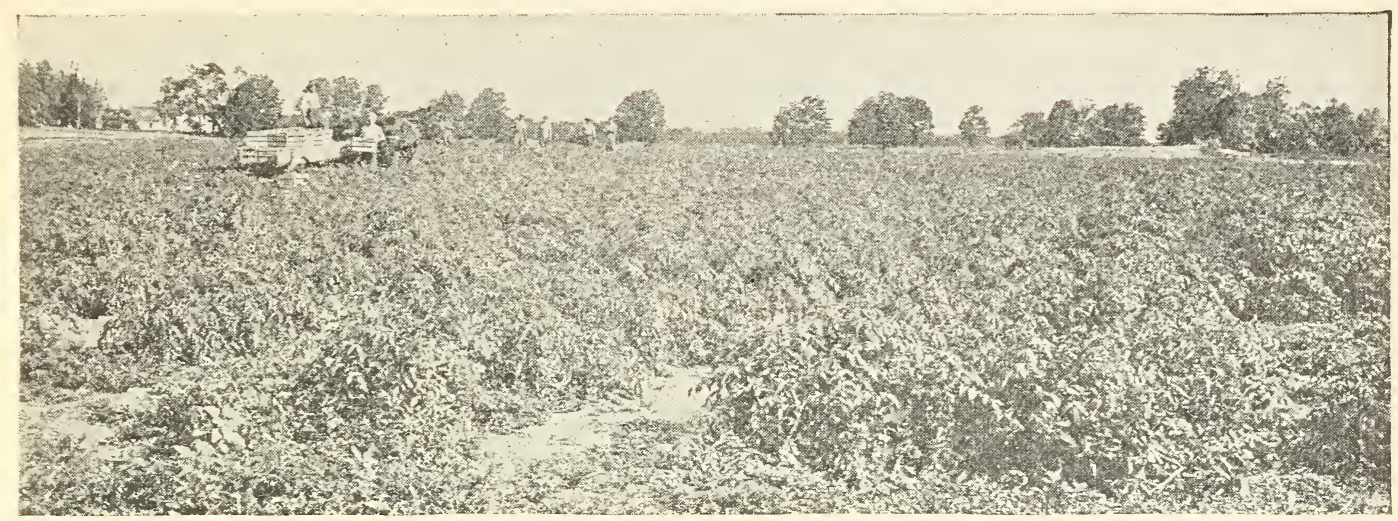

Picking Tomatoes for Seed at Moreton Farm

\section{THIS WHOLESALE PRICE LIST}

This price list is issued especially for the use of the Market Gardener and Florist who use seeds in considerable quantities and quite naturally expect to buy at lower prices than the amateur gardener who buys only small quantities of each kind.

This list does not include all the kinds and varieties of seeds we sell, but only such seeds as are used by Market Gardeners and Florists.

Our complete general catalogue containing description and price of all the seeds and plants we offer will be sent in January. If you do not receive your copy, please let us know and we will send another one at once.

\section{SEEDS GROWN IN THE NORTH}

Some people do not realize how important it is to use northern grown seeds for the northern parts of the country. It has been found that seeds grown in the south produce plants that require a longer time to mature than from seeds grown in the north. This fact is especially important in the case of corn, tomatoes, melons, peppers, ete. Early maturity often means a good profit on the crop, while a late strain of seed might easily prove disastrous.

We are situated near Lake Ontario where the seasons are short and all erops must mature early to escape the frost. This fact insures early maturing strains of such seeds as we raise here.

\section{PRICE AND QUALITY}

Some gardeners tell us that if we can give them seeds of really high quality they do not eare about the price. These are men who know their business thoroughly and know that the extra cost of high class seed is nothing compared with the extra value of the erop over that raised from common seed.

There are other gardeners however-too many of them-who buy seeds of the dealer who offers them at the lowst price. It sometimes happens that good seeds are sold cheap, but in the great majority of eases cheap seeds are of poor vitality or of inferior breeding and therefore produce crops of very ordinary quality and consequently of low value. It is the good crops of high quality that pay.

We endeavor to produce and sell seeds of the highest quality only and to sell them at as low prices as possible consistant with the high cost of raising seeds of this grade. We could buy tomato seed at $50 \mathrm{e}$ per $1 \mathrm{~b}$., but it costs us five times as much to raise the seed the way we do it. An ounce of seed will produce enough plants for an acre. The cheap seed would cost about $8 \mathrm{e}$ and the high grade $40 \mathrm{e}$ - a saving of $32 \mathrm{e}$ on an acre!

\section{WILL THE SEFD GROW?}

When buying seeds a gardener should demand from the seller a statement as to what pereentage of the seed is of good vitality. Almost all commercial seeds contain at least a small percentage of defective or dead seeds that will not germinate. This percentage varies very much in different lots of seed, and it is hard for the gardener to tell how thick to sow in order to avoid an excessive amount of thinning, or a poor stand of plants. Carrot seed, for instance, that contains 60 per cent of live seeds must be sown considerably thicker than a lot that contains 80 per cent.

Harris' Seeds are all marked showing what percentage is of good vitality.

According to Our Tests 98 per cent of this seed germinates
This label is put on every lot of seed (except packets) and tells you what proportion of the seeds germinated in our test of this particular lot.

The seeds are all given accurate tests either in soil or a germinating apparatus so there is no guess work about it. 


\section{ARTICHOKE}

The Globe Artichoke produces the flower buds which are used for food the second year after sowing the seed. The plants are not hardy and require protection in winter north of Virginia.

Large Green Globe. The standard variety. Oz. $\quad 1 / 4 \mathrm{Lb}$.

Lb.

\section{ASPARAGUS SEED}

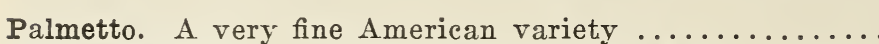

Giant Argenteuil. A large French variety, fine ...........

WASHINGTON. A new rust-resistant strain originated by the U. S. Department of Agriculture at Washington.

For full description see our general retail catalogue.... ASPARAGUS ROOTS. See page 34.

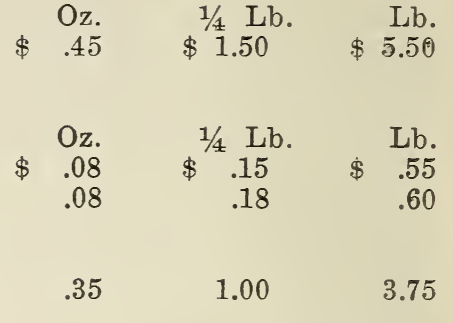

\section{BEANS-Dwarf Wax Varieties}

Of the wax or yellow-podded bush beans, the earliest varieties are Webber Wax with flat pods, and Valentine Wax with round pods. Wardwell's Kidney Wax is a day or two later and has very long flat pods of high quality. This bean is quite apt to rust in wet weather and for this reason Currie's Rust-proof is preferred by many. The pods are broad and deep yellow, but not quite as long as Wardwell's. Sure Crop Wax resembles Currie's Rust-proof but has longer pods and is more prolific. Both mature very early. Burpee's New Kidney Wax resembles Wardwell's but has narrower pods. Hodson Wax is late and very prolific; pods long, narrow and flat. Refugee Wax is also late and has round pods of the highest quality. It is largely used for canning.

Note. We are now offering all seeds by weight instead of measure as formerly. Beans in quantities of over $25 \mathrm{lbs}$. will be sold at the $100 \mathrm{lb}$. rate. We do not sell less than $1 \mathrm{lb}$. of beans at the pound price. A pound is a pint, $60 \mathrm{lb}$. is a bushel.

Sure Crop Wax. Much resembles Currie's Rust-proof, but has longer pods and matures about the same time

WEBBER Wax or "Cracker Jack". The earliest wax bean with flat pods. The pods are long, straight, stringless and quite free from rust. A heavy bearer ..........

Valentine Wax. Extra early, round pods, free from rust. .

WARDWELL'S KIDNEY WAX. Very long, flat, deep yellow pods. One of the earliest and most profitable wax beans for market. Very prolific and of the best

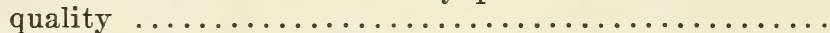

BURPEE'S NEW KIDNEY WAX. Has narrower and thicker pods than Wardwell's and is more prolific ....

ROUND POD KIDNEY WAX. Like Wardwell's with round instead of flat pods. One of the best round

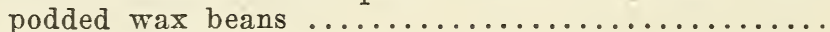

Davis' White Wax. Hardy and prolific. Long, flat yellow

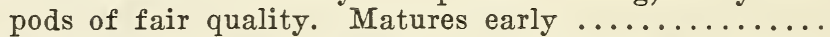

Golden Wax, Improved Rust-proof. Short pods. Early.

Hodson Wax. Late, very prolific, long, straight, flat pods..

CURRIE'S RUST-PROOF BLACK WAX. Hardy and very prolific. An early and profitable market variety.

REFUGEE WAX. Round pods of fine quality, very prolific,

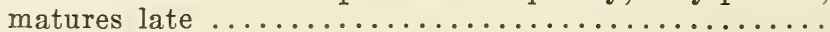

Lb. 15 Lbs. $100 \mathrm{Lbs}$

$\$ .22 \$ 2.40 \quad \$ 15.00$

.22

.30

2.25

2.75

.20

2.10

13.00

.22

2.25

14.00

.22

2.40

15.00

$.22 \quad 2.40$

$.22 \quad 2.25$

$.22 \quad 2.25$

15.00

14.00

14.00

$.22 \quad 2.25$

14.00

.22

2.40

15.00

\section{Beans-Dwarf Green-Podded Varieties}

If your market requires a round-pod bean, Full Measure, Giant Stringless Valentine and Black Valentine are the most profitable. If a flat pod is required, Bountiful is one of the best early varieties.

FULL MEASURE. Very prolific, long, round pods. Medium early and a profitable market variety ...............

Stringless Green Pod. Round, thick, light green pods of

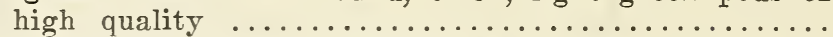

GIANT STRINGLESS VALENTINE. Larger than the old Valentine, and fully as early. Very prolific and one of the very best green-podded bush beans. Round, light green pods of high quality $\ldots \ldots \ldots \ldots \ldots \ldots \ldots \ldots$
Lub.
15 Lbs.
100 Lbs.
(Peck)

$\$ \quad .25$

$\$ 3.30$

15.00 
BLACK VALENTINE. A profitable market bean. Produces immense crops of long, straight, light green pods, round as a pencil and very attractive in appearance........

BOUNTIFUL. Very prolific. Long, flat pods of fine qual-

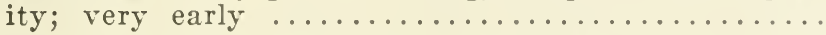

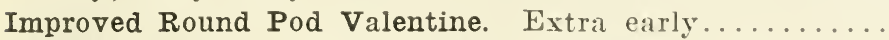

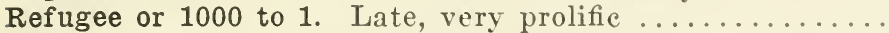

NEW STRINGLESS REFUGEE. A stringless strain of

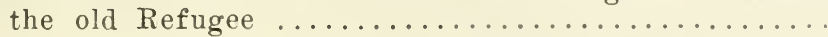

Goddard or Boston Favorite. Used for shelling green....

Ruby Dwarf Horticultural. Used for shelling green......

FRENCH HORTICULTURAL. The best strain of Dwarf Horticultural beans. More prolific and vigorous and free from disease than other kinds. Pods long, straight and highly colored. Matures a little later than Ruby Dwarf Horticultural and has taller vines ...........

$\begin{array}{rrr}+.25 & \$ 2.55 & \$ 16.00 \\ .22 & 2.40 & 15.00 \\ .22 & 2.40 & 15.00 \\ .22 & 2.40 & 14.00 \\ .25 & 2.70 & 17.00 \\ .22 & 2.40 & 15.00 \\ .22 & 2.40 & 15.00\end{array}$

\section{LIMA BEANS-Dwarf or Bush Varieties}

Where beans are sold in the pods, Fordhook is the most popular bush Lima. The beans are of good size and very plump, and the vines are prolific. For shelling, Burpee's Bush Lima of the old type and Burpee's Improved are the best kinds. The beans are large and flat.

FORDHOOK BUSH LIMA (New). A greatly improved strain of Dreer's or Potato Lima. Large pods and very large thick beans of deep green color. The best of

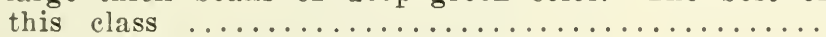

Henderson's Bush Lima. Small, early and prolific ....... BURPEE'S BUSH LIMA, New Wonder Strain. Large, medium early. The most popular Bush Lima ........

Burpee's IMPROVED Bush Lima. (New). Larger pods and thicker beans than the old variety and of deeper green color. A little later than New Wonder Strain...

I. $\quad($ Peck $)$
15 Lbs. $\$ 30 \$ 3.60 \$ 23.00$ $\begin{array}{lll}.25 & 2.70 & 17.00\end{array}$

$\begin{array}{lll}.28 & 3.00 \quad 19.00\end{array}$

$\begin{array}{lll}.30 & 3.15 \quad 20.00\end{array}$

\section{Pole Lima and Other Pole Beans}

Of the Pole Limas, Early Leviathan is the earliest kind with large pods. Ideal is a little later but has larger pods and is very prolific. Challenger has thick, plump beans like Dreer's or "Potato", Lima, and is the best pole variety of this class.

Golden Cluster Wax has immense long, wide, deep yellow pods of high quality as a snap bean. Kentucky Wonder Wax has long, round, yellow pods of fine quality. It is one of the best pole beans with wax or yellow pods.

Scotia and Kentucky Wonder have long, round, green pods of high quality. Lazy Wife has flat, green pods.

EARLY LEVIATHAN LIMA. Very early, large pods. The

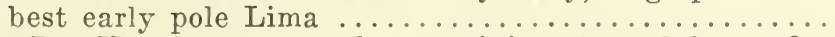

IDEAL. Has immense pods containing 4 to 6 large flat beans of high quality, vines very prolific. A few days later than Early Leviathan but the pods are much

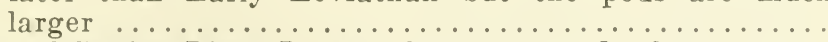

King of Garden Lima. Long pods and large flat beans....

CHALLENGER LIMA. An improved strain of Dreer's Pole Lima. Large plump beans of the "Potato" class.....

Golden Cluster Wax. Produces long, broad, deep yellow

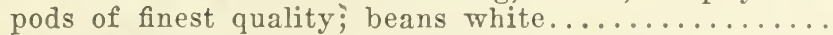

Kentucky Wonder. Long, slender, green pods of fine

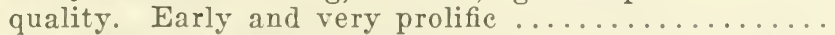

Kentucky Wonder Wax. Long, round, yellow pods, very

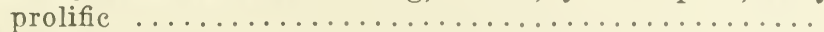

SCOTIA. Long, slender, green pods of the very finest

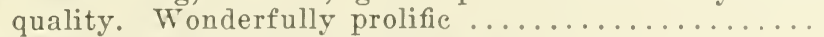

Lazy Wife. Large, flat, green pods; very productive ...

Speckled Cranberry or London Horticultural

(Peck)

Lb. 15 Lbs. 100 Lbs.

$\$ 25 \$ 2.75 \$ 17.00$




\section{FIELD BEANS}

(Prices per 100 lbs. subject to change. Please write for price if a considerable quantity is required.)

Boston Marrow or White Marrowfat. Large, plump, white

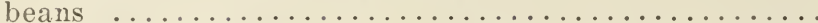

Marrow Pea or White Navy. Small white beans. The

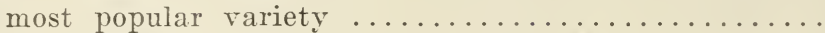

ROBUST PEA BEANS. A select strain of Pea beans that is free from the mosaic disease $\ldots \ldots \ldots \ldots \ldots \ldots \ldots$

Red Kidney. Large red beans, very prolific and a profitable variety. Special disease-resistant strain ............

WHITE KIDNEY. Large, white, kidney-shaped beans: yields heavy erops and is of the highest quality for baking

Lb. $($ Peck

15 Lbs. 100 Lbs.

$\$ 20 \$ 2.10 \$ \$ 13.00$

1.65

\section{Crosby's Egyptian Beet}

\section{HARRIS' SPECIAL STRAIN}

Particular gardeners who want the very finest beets both in shape and color will find this special stock to meet their requirements.

The seed is of our own growing and the most careful selection has been practiced for more than fifteen years until now we have a strain that is practically "fixed" so that the beets come all alike, nearly every one a model for shape and color.

The beets are globe shape, very deep red and perfectly smooth with very small tap roots. The tops are unusually small. This beet grows very rapidly and is ready for market earlier than any other kind we know of. It is much earlier than Detroit Dark Red and Early Blood Turnip.

This is the finest strain of Crosby's Egyptian beet obtainable no matter what price is charged for the seed.

We are glad to say that our seed this year is exceptionally fine and shows high germination. Oz. $15 \mathrm{c} ; 1 / 4 \mathrm{lb} .40 \mathrm{c} ; 1 \mathrm{~b} . \$ 1.25$.

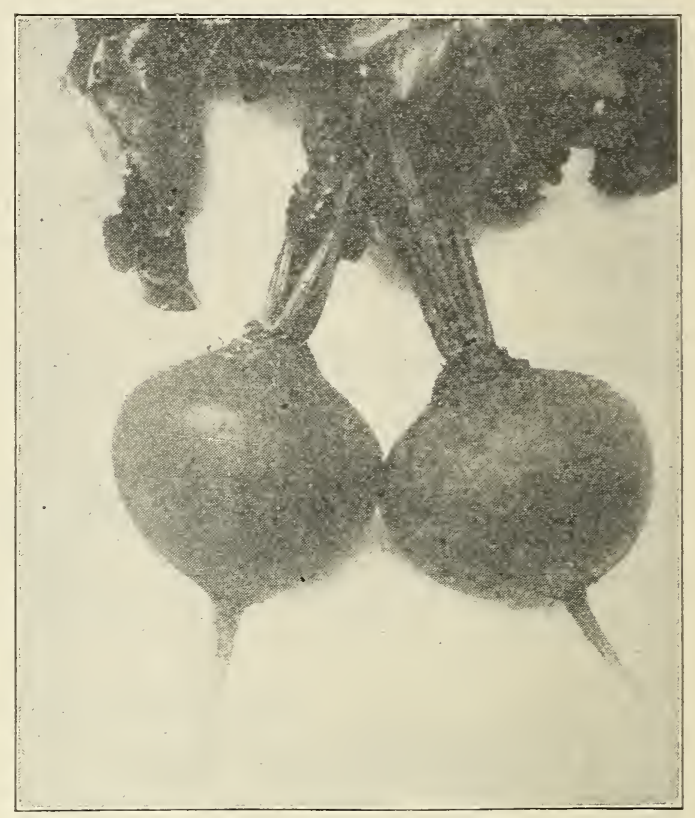

Crosby's Egyptian Beet

Your special strain of Crosby's Egyptian Beet is the nearest perfect in shape, color, ete., of an beet I have grown in forty years of gardening." -C. A. Baker, Milford, N. H., Aug. 9, 1920.

"I like your seeds. Your Crosby's Egyptian beet is especially fine-Very early and of better shape than any seed of that variety that I have ever used. All other seed produced so many flat ones and were no good except for earliest bunching. Yours were good and tender as long as Detroit and uniformly dark colored all through, and in every way ahead of all other beets I erer tried.' P. D. Kemrer, Lancaster, Pa., Jan. 31, 1922.

\section{DETROIT DARK RED BEET-Harris' Selected Strain}

This strain produces beets of uniform giobe shape and deep red color without light rings when cut.

This is a very superior stock, being more uniform than any other strain we have been able to find.

The seed is of our own growing and the greatest care is taken in selecting the beets to set out for seed. The consequence is that this seed produces beets very small tops, fine tap roots and perfect globe shape and very deep color.

This seed costs twice as much to raise as ordinary seed costs, but the crops from it are so much superior that the seed is really worth ten times as much. Oz. $12 \mathrm{c} ; 1 / 4 \mathrm{lb} .35 \mathrm{c}$; lb. $\$ 1.10$.

\section{BEETS}

For early bunching Crosby's Egyptian is the most popular kind; and if a really firstclass strain is used there is no better beet for the purpose. Some gardeners prefer the old flat Egyptian Blood Turnip beet, because it makes salable beets a little quicker than Crosby's. For later use Detroit Dark Red and Edmund's Blood Turnip are excellent. For late fall and winter use it is best to sow the seed about the middle of July in the North and a little later further South. It requires about $10 \mathrm{lbs}$. of seed to sow an acre. 
CROSBY'S EGYPTIAN, Harris' Selected Strain. The finest bred stock of this beet. See description above.

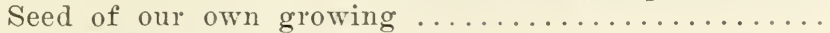

Crosby's Egyptian. Not of our own growing, but a very good strain, superior to most of the seed sold by other

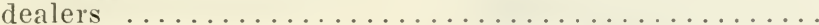

EARLY WONDER. Quite similar to Crosby's Egyptian but flatter than our strain of that variety. Early and of

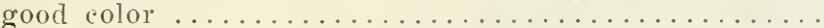

Egyptian Blood Turnip. Flatter than Crosby's, and is preferred by some for early bunching .............

DETROIT DARK RED, Selected Strain. Seed of our own growing, very superior stock. See lescription abore..

Detroit Dark Red. Not of our own growing hut good seed,

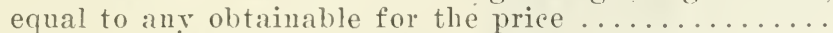

ECLIPSE. Early, globe-shaped and very handsome beet, of somewhat lighter color than Detroit but earlier.....

Edmund Blood Turnip. Large flat beets. Excellent for fall

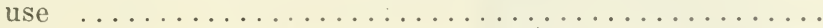

Early Blood Turnip. A good old variety, much like Ed-

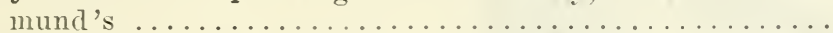

Early Bassano. Large, flat, light-colored beets .........

Long Smooth Blood Red. S to 10 inches long and rery dark

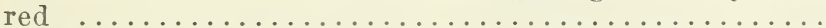

LONG SEASON. A very late variety of fine quality......
Oz. $\quad 1+\mathrm{I}, \mathrm{l}$.

Lb.

\section{Mangels and Sugar Beets for Stock}

DANISH YELLOW GIANT. An immense yielder. TerY

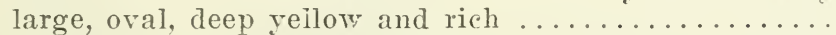

Golden Tankard. Oval and easily harvested; yellow flesh.

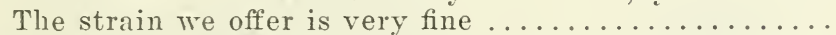
NEW "HALF SUGAR' MANGEL. Intermediate between a sugar beet and mangel. Yields immense crops of

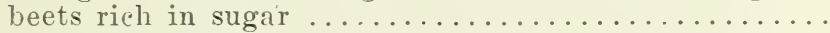

Mammoth Long Red. Tery large, long red roots of good quality. One of the best yielders and keeps well.....

Giant Yellow Eckendorf. Tery large yellow mangel. Blunt at the bottom, easily harvested and immense yielder..

Lane's Improved Sugar Beet. A very large sugar beet for stock.
$\mathrm{O} z$

.08

.08

.08

.08

.08

.08
1, Ll.

I.h.

\section{Beets for Greens-SWISS CHARD or SPINACH BEET}

The Silver Leaf has smooth, light-green leaves with very broad, white ribs and is the most popular variety for market. Lucullus grows very large and has crinkled leaves with yellowish ribs. Both varieties are quite hardy and will survive the winter if given some protection.

Silver Leaf. Large, green leaves with white ribs.

LUCULLUS. Tery large rrinkler leaves with light-yellow Oz. $\quad 1 / 4$ Lb. Lb. ribs

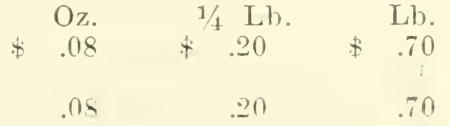

\section{BRUSSELS SPROUTS}

Cultivation is the same as for cabbage or cauliflower. There is always a good demand for the sprouts, and they bring profitable prices.

DANISH IMPROVED. An excellent late variety that yields Or. 1/ Lh. Lb. well if set out before the middle of June in the north

LONG ISLAND IMPROVED DWARF. Special strain. Plants only $18 \mathrm{in.} \mathrm{high} \mathrm{but} \mathrm{are} \mathrm{covered} \mathrm{from} \mathrm{bottom} \mathrm{to}$ top with large solid sprouts crowded close on the stalk and they mature early. We offer proved seed that we know will produce excellent results. 90 per cent of the plants rield high grarle sprouts..

$\begin{aligned} \text { Oz. } & 1 \text { Lh. } \\ \$ \quad 3.5+1.00 & \text { Lh. }\end{aligned}$




\section{CABBAGE}

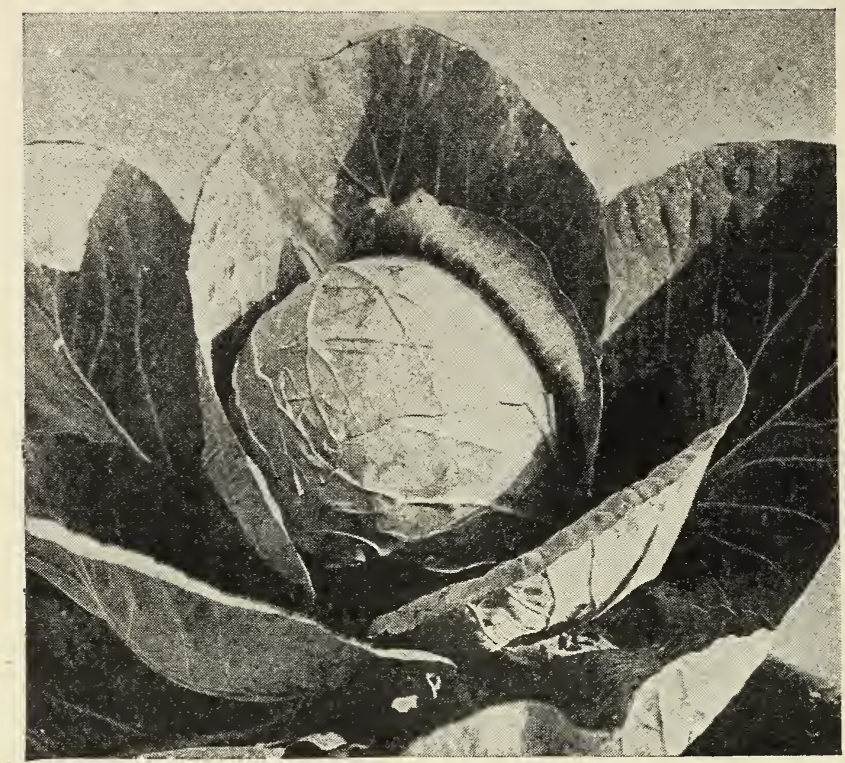

\section{New Early Cabbage "GOLDEN ACRE",}

A wonderfully fine early variety with perfectly round heads of good size and which mature a week earlier than Jersey Wakefield. The heads resemble Copenhagan Market of a very finely bred type. The plants are small with few leaves but the head is of good size, weighing 5 to 6 lbs., as round as a ball, very firm and of good bright green color. Every plant produces a good head and they are all just alike.

Owing to its extreme earliness this cabbage will prove profitable for the first early crop. The supply of seed is so limited that we can offer it only in very small quantities this season. Packet (200 seeds) 20c; $1 / 4$ oz. $\$ 2.00$. (No larger quantities can be sold.)

Golden Acre Cabbage

\section{Midseason Market Cabbage}

This new cabbage has proved to be the most uniform and heaviest yielding medium early variety in our trials the past two seasons. Every plant produces a fine large, round head, every one just alike. This variety is much like Enkhuizen Glory but the heads are larger and mature a few days later. Owing to its perfect uniformity and large size the yield is immense.

We highly recommend this new cabbage for market, shipping, or krout. It is the best variety of its class we have ever seen. $\mathbf{O z}$. $75 \mathrm{c} ; 1 / 4$ lb. $\$ 2.00 ; 1 \mathrm{~b}$. $\$ 7.50$.

This price list does not include all the seeds we sell. For other kind see our complete general catalogue which is issued in January each year.

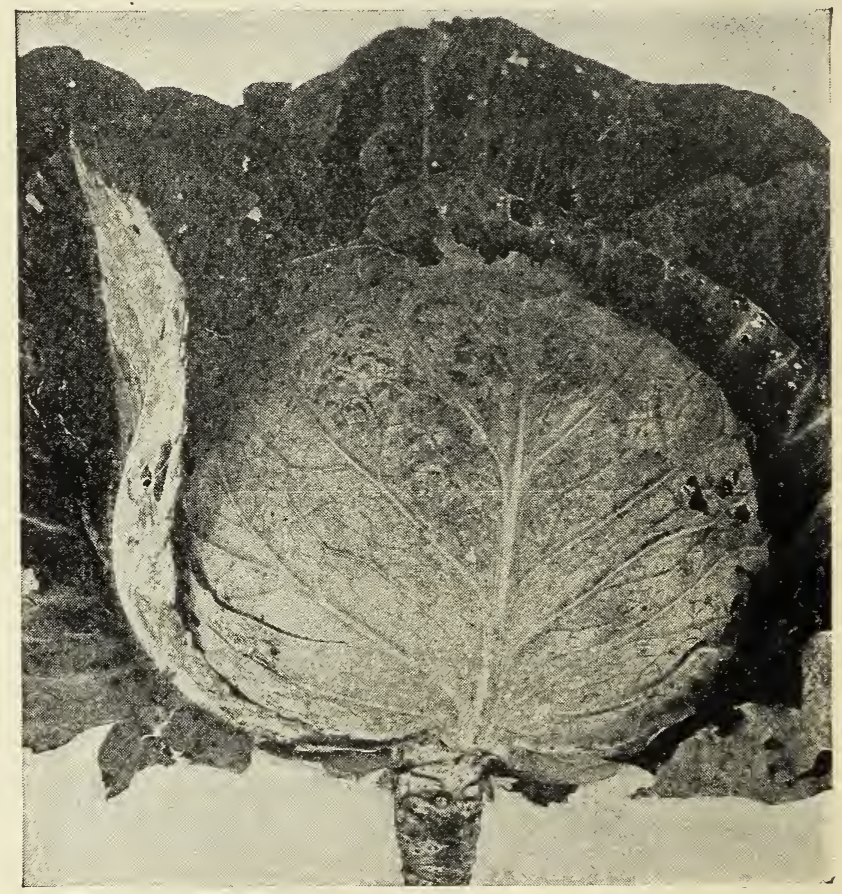

Midseason Market

\section{CABBAGE-Early Varieties}

Jersey Wakefield has long been the standard extra early cabbage, but a round head sells better in most markets and on this account the New Golden Acre and Copenhagen Market have proved more profitable. Enkhuizen Glory has larger heads and is a week later. Burpee's All Head has large flat heads and is a week or two later than the Enkhuizen Glory. 
EARLY JERSEY WAKEFIELD. The standard Early variety. Heads pointed, of medium size and very hard. Our strain is particularly fine, the heads being

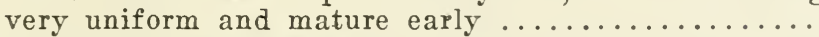

CHARLESTON WAKEFIELD. Larger and 10 days later than Jersey Wakefield. Heads larger around and not

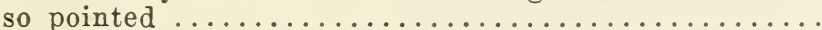

COPENHAGEN MARKET. Heads round, medium size and very solid. Matures very easily and every plant makes

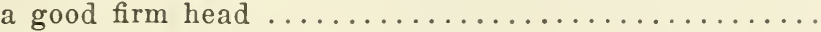

ENKHUIZEN GLORY. A very large, early cabbage. Heads as large as late kinds and mature as early as Charleston Wakefield. Has proved to be a most profitable variety

BURPEE'S ALL HEAD EARLY. Heads of good size, deep, solid and heavy. Matures medium early. Largely used for main crop for fall market and shipping...... Henderson's Early Summer. A fine early flat cabbage.... Stanley. Pointed heads of high quality. Not suitable for

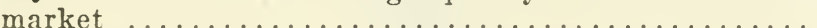

Oz. $\quad 1 / 4 \mathrm{Lb}$.

Lb. $\$$ 35 $\$ .1 .00$ $\$ 3.75$

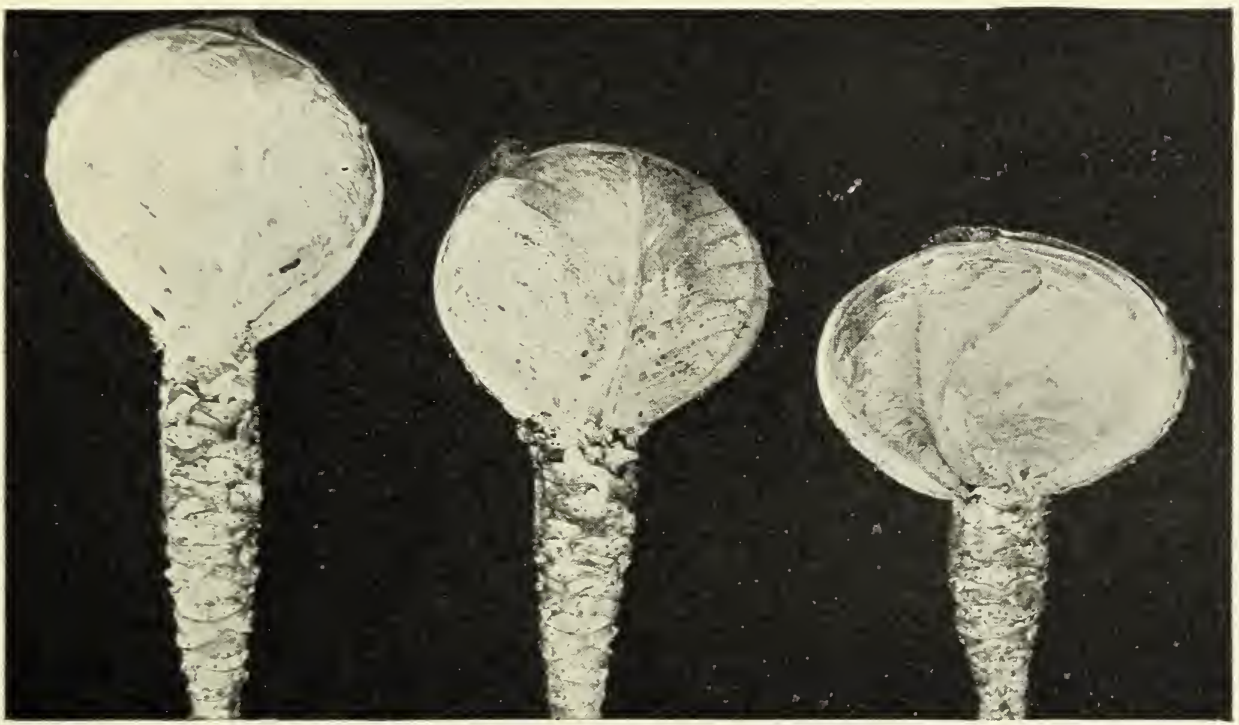

Types of Danish Ballhead Cabbage

Solid Emperor Intermediate

Short Stemmed

\section{CABBAGE-Late or Main Crop Varieties}

For fall use the early varieties are usually the best, but the plants should be set out not earlier than July 1 , in New York State, and later farther south.

Enkhuizen Glory and Harris' Summer Ballhead are both excellent kinds for market or kraut, having large round heads of fine quality.

For late fall and winter market the Danish Ballhead is the most profitable. The Short Stemmed strain we offer yields more than any other of the Danish type, but is not as deep green as the Solid Emperor or Tall Stemmed strain, which has smaller heads and does not yield quite as many tons per acre. The Intermediate strain is halfway between the two, having shorter stems than the Solid Emperor and larger heads. It is a very fine Danish Cabbage.

Savoy cabbage is often a profitable crop for home market. Red Cabbage is also profitable on good, rich land.

Volga. The heads are large, round and solid; a heavy cropper $\$ \begin{array}{llll}\mathrm{Oz} . & .30 & \$ 1 / 4 \mathrm{Lb} \text {. } & .85\end{array}$

HARRIS' SUMMER BALLHEAD. Large, round, solid

heads which mature medium early. One of the very

best kinds for fall market or krout .............. 
DANISH BALLHEAD, Solid Emperor Strain. A very fine strain of the genuine Danish Cabbage. Heads round (not flat) and deep green and very hard. Stems rather long. The best keeper. Proved Seed.............

DANISH BALLHEAD, Intermediate. Has shorter stems and larger heads than the Solid Emperor and is of deeper green color than the Short Stemmed strain. A very

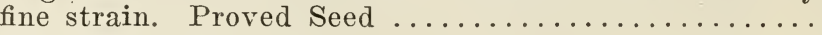

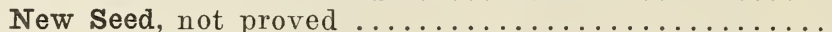

DANISH BALIHEAD, Short Stemmed. Matures quicker than the Solid Emperor Strain, has shorter stems and larger heads, but not quite as deep green color. Proved

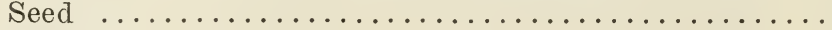

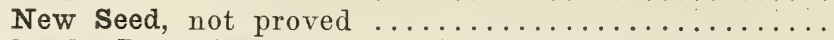

Surehead. Deep, heavy heads. A good, late variety....... Succession. A popular cabbage for fall market ..........

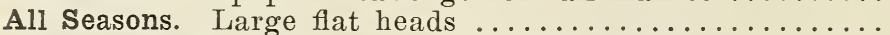
Premium Flat Dutch. Old standard kind. Large, heavy head Winningstadt. Pointed heads of medium size ............ RED DANISH STONEHEAD. A new red cabbage much like a red Danish Ballhead. Grows to a good size and

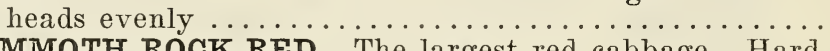

MAMIMOTH ROCK RED. The largest red cabbage. Hard, round deep red. One of the best red varieties for

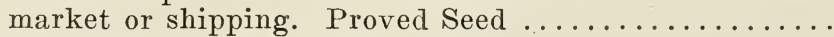

SAVOY, Perfection Drumhead. Heads large and quite firm

SAVOY, Sutton's Best of All. Large heads, quite firm and of a light green color. Produces the largest heads of

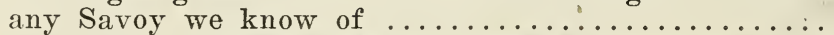

$\mathrm{Oz}$

1/4 Lb.

Ll,.

$\$$

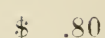

$\$ 3.00$

\section{.30}

.90

$$
.80
$$

$\begin{array}{lll}.30 & .90 & 3.50 \\ .25 & .80 & 2.75 \\ .30 & .75 & 2.75 \\ .30 & .75 & 2.75 \\ .30 & .75 & 2.75 \\ .30 & .75 & 2.75 \\ .30 & .75 & 2.75\end{array}$

1.00

1.00

.80

3.75

3.00

3.00

\section{CHINESE OR CELERY CABBAGE-PE-TSAI}

This Chinese cabbage has proved to be a very profitable crop for muck land. There is a good demand for it from New. York and other large markets in carload lots. The seed is sown in July or August and the crop matures in eight to ten weeks. The heads grow nearly two feet tall and are compact and heavy. We have a fine strain. Oz. 25c; 1/4 1b. 75c; 1b. $\$ 2.75$.

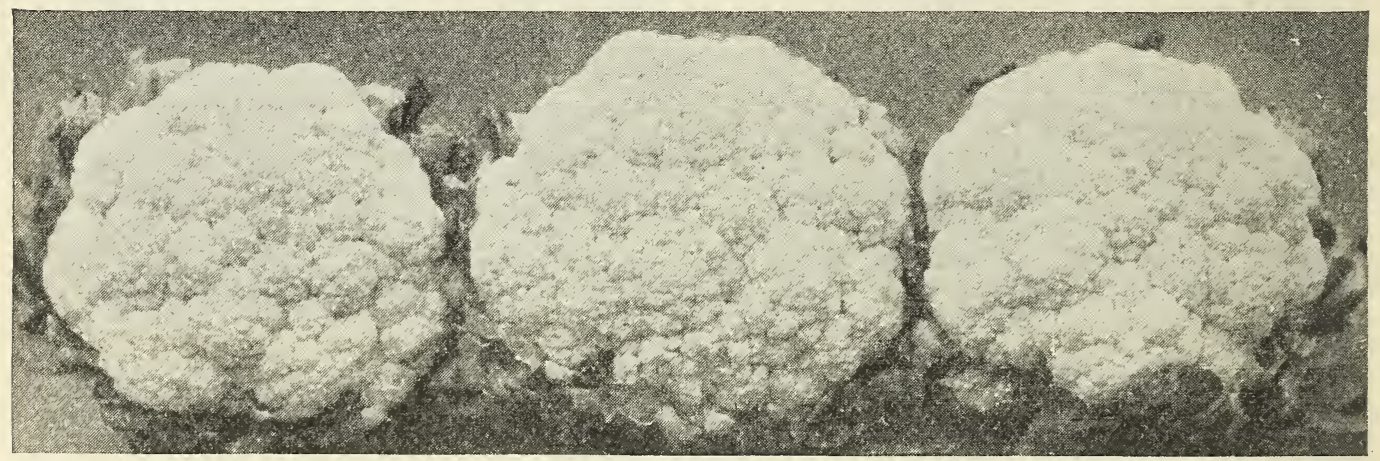

Snowball, Perfected Strain

\section{CAULIFLOWER}

Snowball, of the best strain, makes large solid heads quite early. There is usually not much demand for cauliflower before September, so the plants should be set out from June 15th to July 10th. The later plantings usually produce larger and firmer heads. "Danish Perfection" has more leaves than Snowball which protects the head better. It is a week or ten days later than Snowball, and a little earlier than Danish Giant or Dry Weather, which produces large solid heads, but should be set out earlier. Large Algiers makes loose, flat heads of large size and of high quality, but not of the best form for market.

SNOWBALL, Perfected Strain. A very fine improved Oz. $1 / 4 \mathrm{Lb}$.

Lb.

strain of the true Snowball type. The plant is dwarf and compact and the heads are large, solid, snow white, and with no protruding leaves when well grown under favorable conditions. Matures early but usually the best heads are obtained from plants set out rather late. The seed we offer is the very finest strain obtainable, $95 \%$ of the plants make good heads. There is no sense in paying more for the seed than we charge, as no better seed can be obtained at any price.......1/4 oz. .60 
Danish Giant Snowball or "Dry Weather." Ten days ol' two weeks later than Snowball and of more vigorous growth and stands drought better........ 1/4 oz. .65

DANISH PERFECTION. A new strain of Snowball CamliHower with more leares to cover the head, which does away with tring to some extent. Heads rery solid and without protruding leares. Matmes a week later than snowball ..................... oz. .6.5

Erfurt Early Dwarf. Murh like Snowliall, but not quite

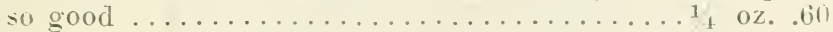

Large Algiers. Large, rather loose heads, but of fine quality ................

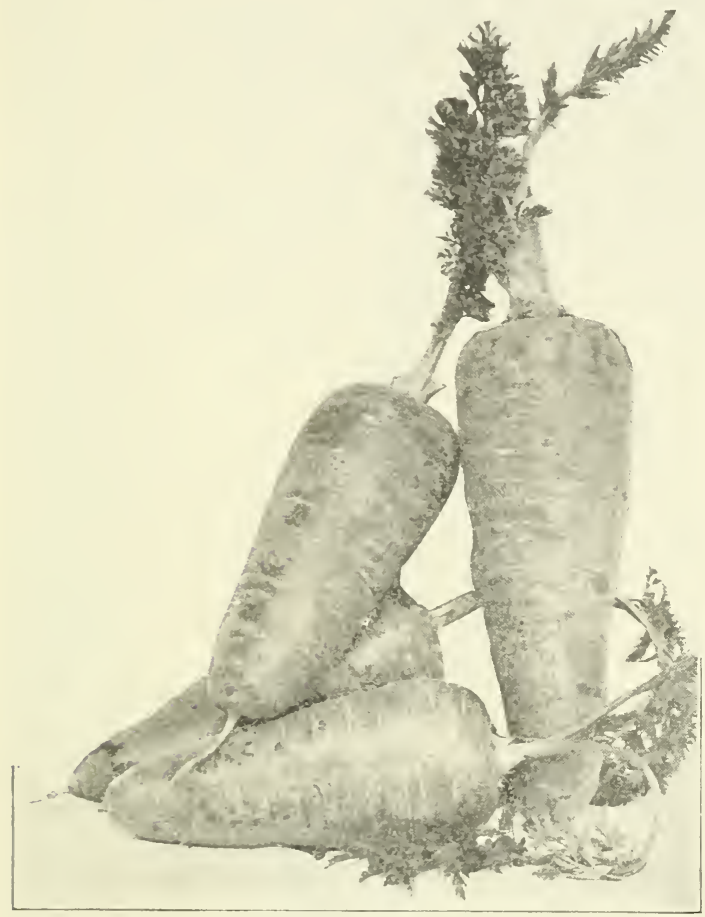

Chantenay

Danvers
Oz. $\quad 1+$ Lb.

I.b.

$\$ 2.10+7.50+28.00$

$2.10 \quad 7.50 \quad 28.00$

$2.00 \quad 7.00$

$1.35 \quad 3.50$

\section{CARROTS}

Chantenay is considered the best rariety for market or talble use. The roots grow very smooth and not too long. Danvers Half Long grows an inch or two longer and rields more, so is preferred when the crop is to be used for feeding stock. Coreless or Amsterdain Foreing is of fine quality for table use.

Oxheart makes a nice short, thick carrot for bunching. Early French Short Horn is very short, but grows rapidly and is best for forcing. All of these varieties are leep orange in color.

CHANTENAY. The most popular market variety, six inches long, stump-rooted, deep orange color and very smooth. Pkt. $10 c$; oz. 25 c; 1b. 80c.

DANVERS' HALF LONG. Grows about 8 in. long, deep orange color all through; not quite as smooth as Chantenay. A heary cropper and valuable for stock feeding and market. Pkt. 10c; oz. 25c; 1b. $75 c$.

Oz. $\quad 1 / 4 \mathrm{Lb}$.

Lb.

CORELESS or Amsterdam Forcing. The carrots grow about 5 in. long and 2 in. through and the same size the whole length. The end is blunt and with very fine rat-tail root. The color is deep orange red all through the root including the core, hence the name "coreless", is the small core is inconspicuous. This is a beautiful ('arrot for bunching or to market in bulk ...........

OXHEART or Guerande. Short, thick carrots, user for bunching and table use. Tery easily pulled. About $t$ inches long, deep orange rellow, and of fine quality.

MASTODON or WHITE VOSGE. Large, white carrot for stock feeding. Immense yielder. 8 to 10 inches long.

Long Orange. Roots a foot long, rields large crops.......

Early French Short Horn. For forcing. About 3 inclies long: very early

.11

.11

.$\overline{1 .}$

\section{CRESS}

Extra Fine Curled, also called "Pepper Grass",

WATER CRESS, Improved Broad-Leaved. Much better

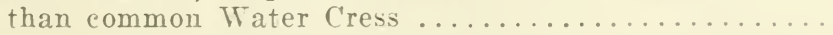

VOTE We do not sell half ounces unless the price per ounce is 300 or wer 


\section{CELERY}

Two-thirds of all the celery grown is Golden Self-Blanching, or "Paris Golden,"' which is the same thing. This is the most profitable rariety for market up to January. For later use, the green rarieties should be used. Easy Blanching blanches quickly and can be marketed early. Franch's Success is one of the rery best for late winter market and keeps longest. Columbia of a good strain, is excellent to follow Golden Self Blanching.

\section{GOLDEN SELF BLANCH. ING or Paris Golden.}

We can now offer two strains of this popular variety. There has been considerable trouble experienced by growers during the last few years with blight and root-diseases which attack the Golden Self Blanching much more severely than other varieties. There has now been developed by a French grower a strain that is practically free from rust and other diseases. It also grows with much greater vigor and attains a larger size than the old strain. The stalks are taller and not quite so broad. This is undoubtedly the best strain for early market. Some growers prefer the old strain for storage, while others like the new. On rich muck the new strain grows very large and may get too tall if it is set out before the middle of July. See prices on next page.

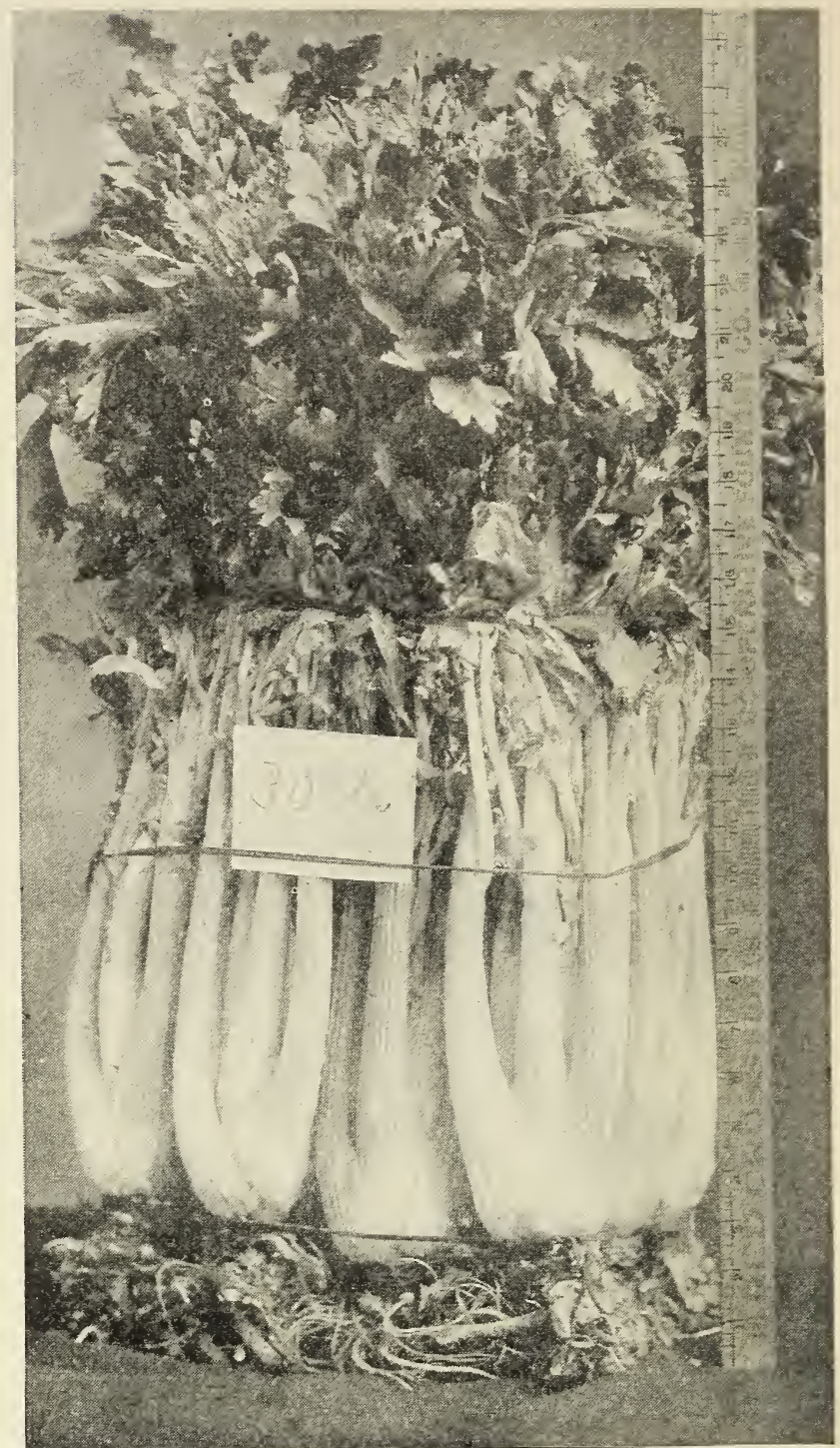

Golden Self Blanching From

\section{EASY BLANCHING or Sanford Superb Celery}

We find this new celery a first-class variety to follow Golden Self Blanching. It is of the same dwarf, compact habit of growth, blanches easily and quickly, and is of fine quality. The leaves are green and the stalks pure white when blanched." It is superior to the Golden Self Blanching in keeping qualities. We have kept a lot of it in good shape until spring, and set it out for seed. We can now offer seed of a superior strain of this variety grown by C. E. Garrahan, a well-known celery grower. The celery has very heavy stalks, blanches easily, and is perfectly firm and solid. We highly recommend this strain. Oz. $95 \mathrm{c} ; 1 / 4 \mathrm{lb} . \$ 3.25 ; \mathrm{lb} . \$ 12.00$.

\section{FRENCH'S SUCCESS CELERY}

We do not know of any green celery quite equal to French's Success. The stalks are of good length, very thick, firm and brittle. When grown from our selected seed there are no soft stalks.

The keeping qualities of this celery are remarkable. It is not difficult to keep it in good condition until March. It is a better keeper than Columbia, and heavier, more uniform and more solid than Winter Queen and Giant Pascal.

Beware of seed of this variety offered by other dealers. We know by our trials that all of it is far inferior to our own original strain, which we got from Mr. French himself over 15 years ago. Crop of seed very short again this year. Oz. 95c; $1 / 4$ lb. $\$ 3.25 ; 1 b . \$ 12.00$ 
grown by the originator in France.

New Strain. Blight-resistant and grows more rapidly and gets larger than the old strain........

Old Strain. Proved seed from which a crop has been grown so we know it is of the highest quality. There were no soft or green stalks in the (rol) GOLDEN ROSE, or Rose-Ribbea Self Blanching. Like Golden Self-Blanching tinged with red. Keeps better and is of finer flaror . . . . . . . . . . . . . . . . .

White Plume. We have a very fine, pure strain of this

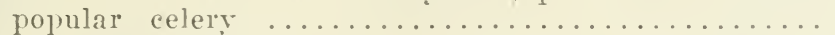

EASY BLANCHING. Also called Sanford Superb......

Columbia. Much resembles Golden Self-Mlanching in growth and appearance, but is a green celery and loes not blanch so quickly and keeps longer. A valuable

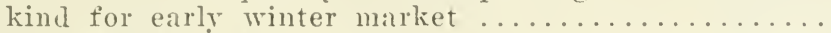

Newark Market. Tery similar to Easy Blanching of a good strain. A fine variety for fall or early winter

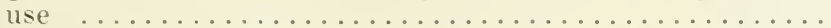

FRENCH'S SUCCESS. The best keeper we know of. Keeps well until spring. Tery firm and crisp, never

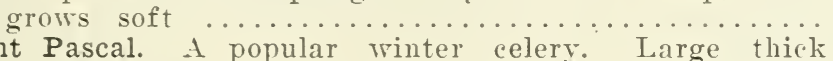

Giant Pascal. A popular winter celery Large thick CELERIC (Turnip-rooted Celery). Large, Smooth Prague Delicacy. A new rariety of Celeric of medium size and

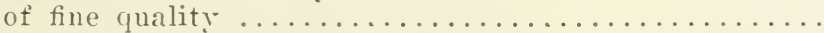

+. 1.00

$\$ 12.00$

$1 .(11)$

2.75 12.00

\section{SWEET CORN}

\section{ALPHA-The Earliest Sweet Corn}

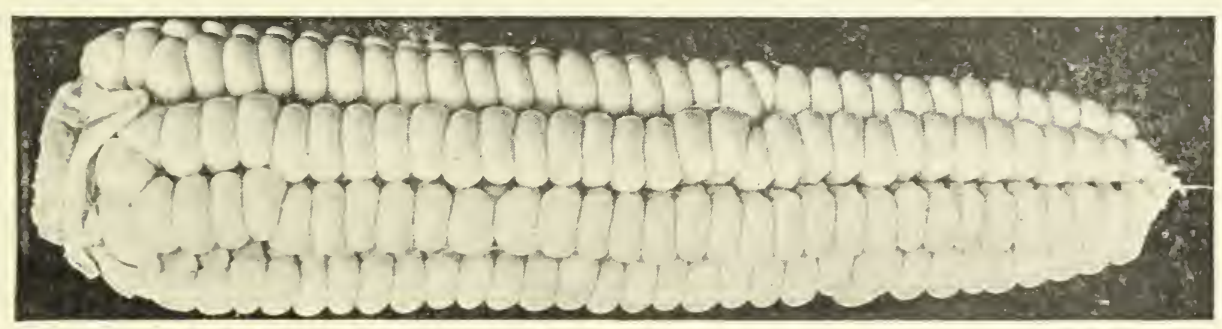

We have never before found a true Sweet Corn that was any earlier than our strain of Mammoth White Cory. The past season in our trial grounds we discovered a variety that matured three or four days earlier than any other kind. This variety is ealled "Alpha.", The ears are 5 to 7 in. long with 8 rows of large white kernels and has a white cob. The stalks are only 4 to $5 \mathrm{ft}$. high.

Owing to its extreme earliness the Alpha will undoubtedly prove a profitable corn for the market grower. With this variety it will be perfectly possible to get corn on the market 4 days to a week earlier than any one else and get the high prices that are always paid for the first corn. Lb. 35c; $12 \mathrm{lbs}$. (peck) \$3.25; $25 \mathrm{lbs}$. or more $26 \mathrm{c}$ per $1 \mathrm{~b}$.

\section{HARRIS' MAMMOTH WHITE CORY}

There are many varjeties of Sweet Corn claimed to be the earliest. We have tried everv kind we could get the seed of and planted it side by side with our strain of Mammoth White Cory on the same day. No kind has matured earlier except the new "Alpha", which has smaller ears.

Harris, Mammoth White Corn has good, large ears 6 to 7 in. long, 8 to 10 rowed pure white and of fine appearance.

The stalks are small but often carry two large ears which grow quite low down. This "orn is "Mammoth" only in the sense that it has much larger ears than the old Cory Corn.

It is a profitable corn to raise because it gets on the market before any other kind having ears equally large, and always brings the highest price. It has sold as high as $\$ 1.00$ per doz. on the Rochester market. Seed of our own raising, selected for earliness and large 10 rowed ears. Lb. 25c; 12 lbs. (peck) $\$ 2.00 ; 25$ lbs. or more 16c per lb. 


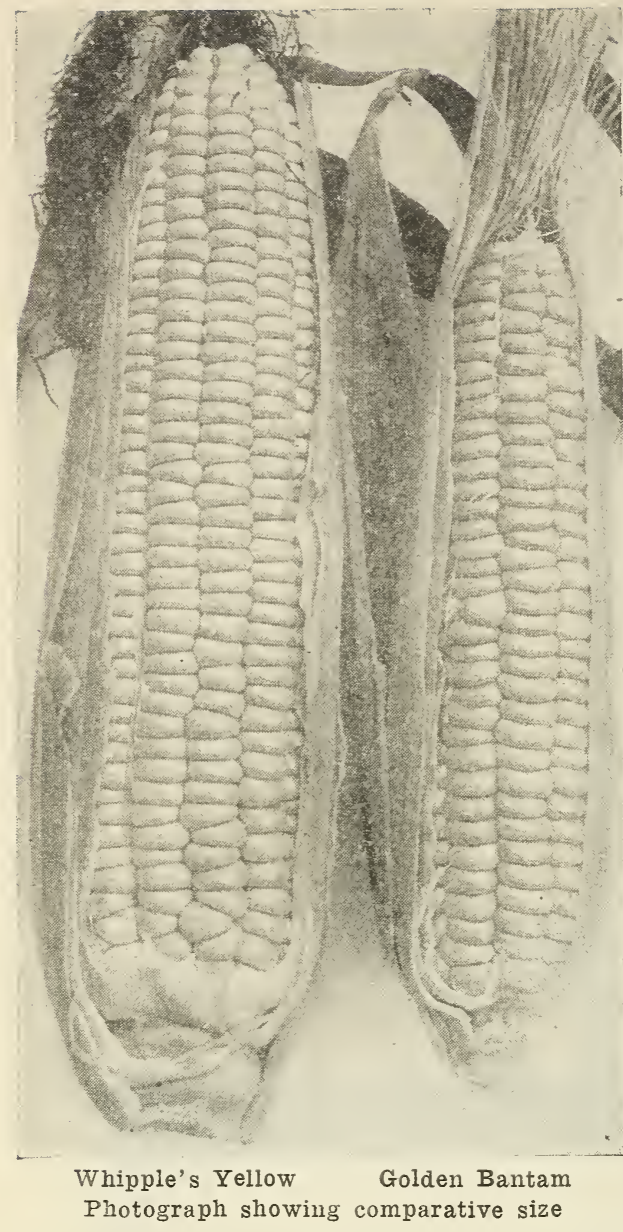

\section{WHIPPLE'S YELLOW Sweet Corn}

Earlier than Bantam and as large as Evergreen

This is a wonderful early yellow corn that ought to be very profitable to raise for market. The ears are very large, 8 to $9 \mathrm{in}$. long, having 12 to 16 rows of deep kernels. They mature ready for use three to four days earlier than Golden Bantam. The quality of the corn is rery fine, but possibly not quite as street as Buttercup.

Its large size and earliness should make it a most profitable market rariety. The ears are of the same type as Whipple's Early and mature at about the same time. Lb. 35c; 12 lbs. (peck) $\$ 3.00 ; 25 \mathrm{lbs}$. or more 22c per lb.; EARS, $\$ 10.00$ per 100 ears.

"It may" be of interest to you to state that I planted Whipple's New Yellow corn on MaY 19th and picked good full ears on July 24th. Quality delicious. A wonderful variety for the market gardener. "- $-\mathrm{H}$. IT. Leggett, Schuylerville, . N. Y., July 25, 1922.

It may interest you to know we got our first corn (Whipple's New Yellow) on July 1st. Beats anything in our experience." -R. H. Rennie, Chicago, Ill., July 4th, 1921.

\section{Pocahontas Sweet Corn}

This corn has proved to be the most profitable market variety in past years.

It matures only three or four dars later than the very earliest kinds and has ears twice as large.

The ears are really immense. Often measuring 10 and 11 in. long with 8 to 10 rows of very large kernels.

The stalks are of medium height and often produce two big ears.

We have this corn so well bred that practically every ear is well filled and of large size so the rield of salable corn is rery large. The ears are so large and handsome and come so early that it always brings the top price. Lb. 25c; $12 \mathrm{lbs}$. (peck) $\$ 1.70 ; 25 \mathrm{lbs}$. or more $13 \mathrm{c}$ per $\mathrm{lb}$. EARS $\$ 5.00$ per 100 ears.

-Pocahontas is, we think, the sweetest white corn grown and certainl rields well. most erery stalk baving two fine ears. Nimms Hrbrid has given excellent satisfaction as the ears are so rery large and "e hare had as high as 4 ears on a stalk. three of which were good marketahle ears. “-Evan J Robinson. Alden. X. I., March 10, 1922.

\section{MIIMIS' HYBRID SWERT CORN}

This corn was originated by one of our gardener friends, Mr. J. Wr. Mimms. It is the largest and best medium late corn we know of.

The ears are very large, often nearly a foot long, with 10 to 12 rows of large white kernels that are very sweet and delicious. The ears are longer than Stowell's Erergreen and not quite so large around. They mature before Erergreen and alwars command a good price in market on account of their large size and high quality. The stalks grow $i$ feet tall and produce nearly twice as many ears per acre as the Evergreen.

Gardeners will do well to try this new strain. We are quite sure they will find it a valuable second early kind to come between the small extra early varieties and Erergreen. Lb. $25 \mathrm{c} ; 12 \mathrm{lbs}$. (peck) $\$ 1.70 ; 25 \mathrm{lbs}$. or more $13 \mathrm{c}$ per lb. EARS, $\$ 8.00$ per 100 ears.

'The Iimms' Hybrid Sweet Corn is certainly fine. I have raised it two seasons and have had the best in the market.' - E. B. Underhill, Poughkeepsie, I. Y.

'The Mimms' Hybrid Corn sells for better money than any other kind on the Milwaukee market. Alex. Clereland, Milwaukee, Wis. 


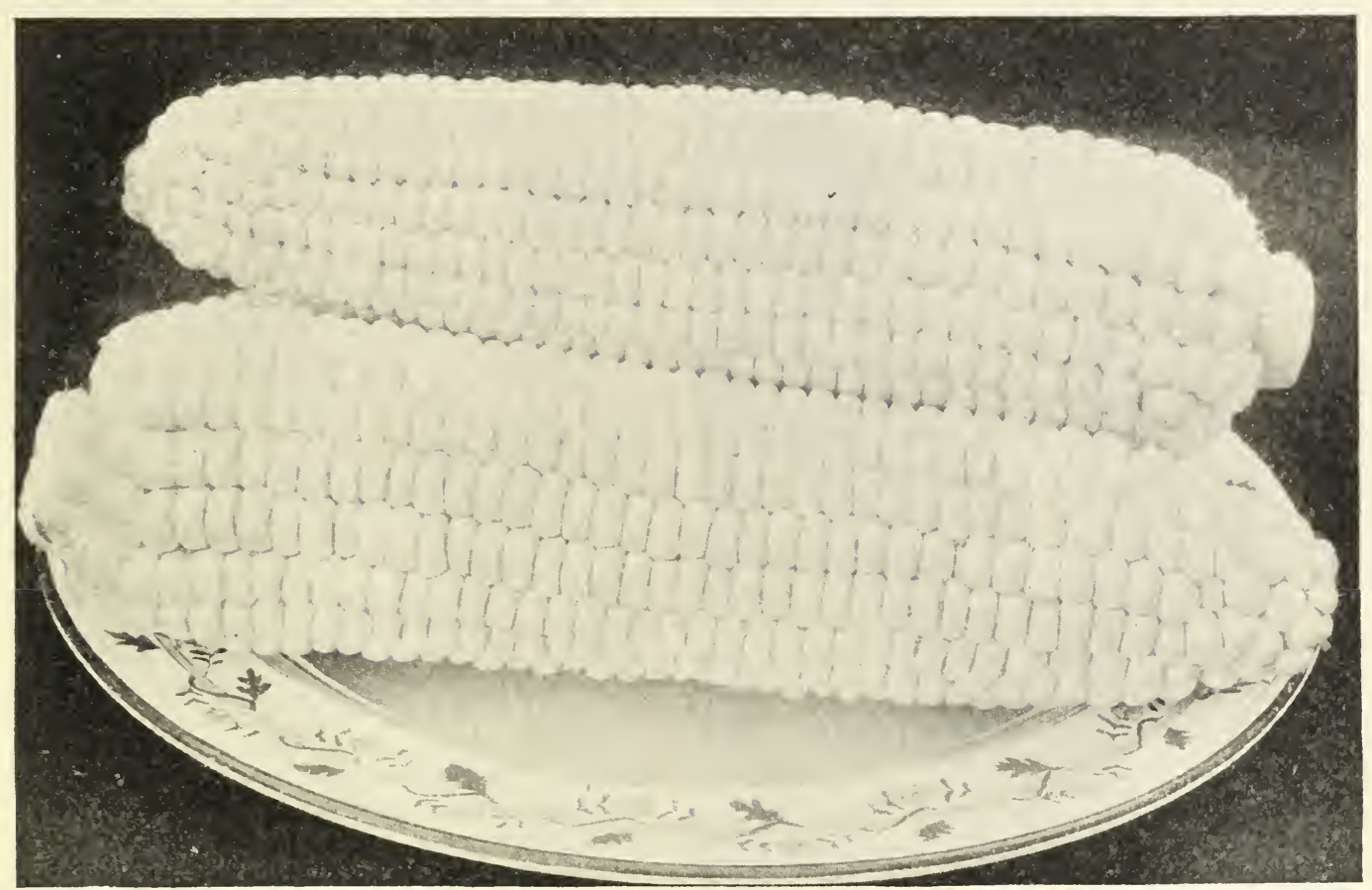

\section{WHIPPLE'S EARLY SWEET CORN A Wonderful New Early Variety}

\section{Looks like Evergreen and is as early as Cory.}

We introduced this corn in 1919 and claimed it has the largest ears of any corn that matures so early. We have received many very flattering reports from gardeners who tried it and we are quite sure that all who grew it last season were more than pleaseil with it.

To describe it briefly it is like Stowell's Evergreen in size and shape, but matures very early - as early as Pocahontas and Red Cory, much earlier than Kendel's Early Giant. Metropolitan, Golden Bantan, etc. The quality of the corn is far superior to Evergreen. the corn being sweet, tender and delicious.

A profitable market variety-Think of putting on the market a big 16-rowed car of corn as early as others are bringing in Cory! It sells on sight and at top prices. Fully half the stalks liave two large ears even when planted quite close together. The vield therefore is immense.

In our opinion it is the most valuable early Sweet Corn ever produced and will take a prominent place in the list of varieties best suited for the market grower. Those who plant this corn now will reap the benefit.

The ears are $i$ to $s$ inches long and very large around, as they have 14 to 18 rows of good size kernels. Each ear is filled right out to the tip. The kernels are long and narrow like Evergreen.

We offer seed of our own growing of highest quality. Cret hearlquarter seed. It is very highly bred and the true originator's strain. Lb. $25 \mathrm{c} ; 12 \mathrm{lb}$. (peck) $\$ 2.00 ; 25 \mathrm{lbs}$. or more $16 \mathrm{c}$ per lb. EARS, $\$ 9.00$ per 100 ears.

\section{What Gardeners say About Whipple's Early Corn.}

"Yom Whiprle"s Early corm is a fine thing. It proved as early as Corn and the ears are twice is large."-Eugene Thayer, Bowie, Wl., March 6. 192.2

"The Whipple's Early Corn which we planted II 14 th had some fine ears fit for use July the ilrs. 1. Duke. Muskogee. Okla.. Aug. 9. 1921.

Your Whipple's Early (corn can"t be beat. The Golden Bantam corn stands high, lut aftor T make one sale of Whipples and they try it, it is clear sailing. I shall plant more next year. I an much pleased with the seeds I received from you," Cassander Gilmore, Raynham, Mass., Sept. 23. 1921. "I was pleased with Whipple's Early sweet Corn. Had ears 74 days from planting that wighes one and one-half ilss, each." Fred firiftin. Hamburg, N. Y.. Sept. 6, 1921

'I planted two quarts of your Whipple's sweet Corn last vear along side of Early Fordhook and at the same time and on the identically same ground, and helieve me, I was surprised when the Whipple Corn with its big ears was ready to pull the same day the Fordhook corn was. Ind such a contrast in the size of the ears of corn! It will certainly make friends for you wherever you sell it:" Humpton, Coaterville, Pa.

"I take this opportunity to congratulate rou and Mr. Whipple upon Whipple's Early as large. The quality is equal to Country Gentleman and is two or three weeks parlier. It i the luest all-around corn that I have trierl for the Northern latitudes." -I. F. Trihnson: Rirhfield siring 


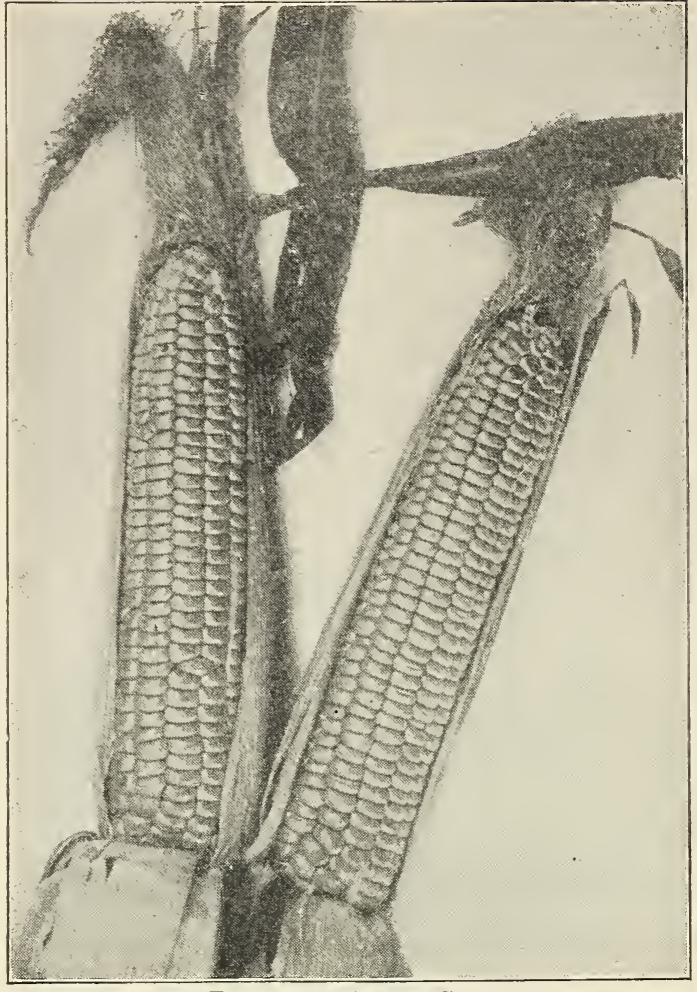

Buttercup Sweet Corn

\section{BUTTERCUP SWEET CORN}

\section{The Sweetest Corn Grown}

The market in many eities now demands a yellow Sweet Corn of the Golden Bantam type. The Bantam is small and does not yield well. In the Buttercup we have a corn that resembles the Bantam very much, but has ears nearly twice as large and yields much more and it matures at the same time as the Bantam. The quality in our opinion is better than Bantam or any other corn. It evidently contains much more sugar and is therefore sweeter than other varieties.

The demand for yellow Sweet Corn is increasing every year and it always brings higher prices in the larger eities than white corn.

After trying practically all the different kinds of yellow Sweet Corn now being offered we are convinced that Buttercup and Whipple's New Yellow are superior to any other varieties that mature as early.

The Buttercup is really an improved Golden Bantam with larger ears which mature just as early. It always sells better than the small ears of Bantam.

The ears are 8 to 10 in. long and have 8 to 12 rows. Many stalks produce two ears.

We offer seed of our own raising. It is of a "thoroughbred" strain and the germination is perfect. Lb. 25c; $12 \mathrm{lbs}$. (peck)

$\$ 1.70 ; 25 \mathrm{lbs}$. or more at $13 \mathrm{c}$. EARS, $\$ 7.00$ per 100 ears.

\section{What Gardeners say of Buttercup Corn:}

"Buttercup corn is the easiest money ever. Had everyone in town stopped for corn. Iots wondered how I got Golden Bantam to grow so large! It does not harden so quickly' either as Henderson's Golden Rod."-W. H. Toplin, Milford, Mass.

"I bought from you one pint of Buttercup sweet corn and planted same 4 kernels in a hill. Family of 5 used all we wanted, sold 75 doz. ears at $20 \mathrm{c}$ per dozen-\$15.00. I find this corn better than you recommended.

It is sweeter than Golden Bantam. I have ears 11 inches long."-G. W. Stanton, Lnion Center, N. Y.

"I was especially pleased with the Buttercup corn which was new to me, and I believ' $i_{\imath}$ is much superior to Golden Bantam."-IV. B. Snow, Raleigh, N.C.

"I wish to advise jou that the Buttercup corn was the earliest and sweetest of nine kinds that I raised last year. Even the name "Buttercup" was worth the price." - Herbert Durrell Smart, Nashua, N.H.

\section{CORN ON THE EAR}

If desired, we can furnish sweet corn of most of the varieties described on these pages unshelled. It is much more trouble and much more expensive to pack and ship ears than shelled corn, so we have to charge a somewhat higher price for the ears. The corn, however, is really no better. The shelled corn is from the same crops and all poor ears are rejected before shelling, so the same results are obtained from either shelled or unshelled seed. 25 ears or more are sold at the 100 price. No smaller quantities can be supplied.

\section{HARRIS' PEDIGREE SWEET CORN}

We have long made a specialty of raising sweet corn seed of the highest possible quality. It is largely raised on our own farms where selection can be made to the best advantage while the corn is growing. Selection for "breeding stock' is made from stalks that produce the first mature ears in the case of the earliest varieties and from stalks that rield the largest and best ears of the later kinds.

When the corn is ripe it is placed in drying houses where it is thoroughly dried under moderate heat. This insures strong germination. Corn of our orrn raising usually germinates 98 to 100 per cent eren in most unfarorable seasons.

There is another point that should not be overlooked. It is a well known fact that sweet corn grown in the North is far better both in quality and early maturity. than the same variety raised in the South or Western states. We are as far north as corn can be successfully raised for seed purposes, so the seed raised here produces corn that matures early and is of the highest quality. 


\section{SWEET CORN}

Our sweet corn is very carefully cured and is of strong vitality. The percentage that germinates in our tests is marked on the label of each lot we sell, so the planter can tell just how thick to plant.

Note: $25 \mathrm{lbs}$. of one rariety will be supplied at the $100 \mathrm{lb}$. rate

ALPHA. The Earliest rariety. See page $11 \ldots \ldots \ldots$ 12 .

WHIPPLE'S YELLOW. A grand new early yellow corn.

See page $11 \ldots \ldots \ldots \ldots \ldots \ldots \ldots \ldots \ldots \ldots \ldots \ldots$
EARLY MAYFLOWER. Extra early: pure white corn of fine quality. Ears of good size and 10 to 12 rowed....

HARRIS' MAMMOTH WHITE CORY. The earliest Sweet Corn and one of the most profitable for market.....

POCAHONTAS. Extra early, large ears, white cob; as early as Red Cory and much larger and of finer quality. We consider this one of the best early Sweet Corns. Many of our customers hare found it a very profitable vari-

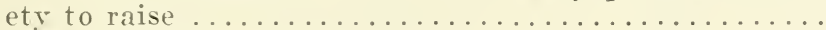

MIMMS' HYBRID. One of the best and most prolifie

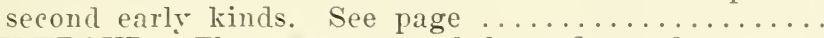

BUTTERCUP. The sweetest and best flarored corn we know of. Kernels golden yellow; ears much larger than Golden Bantam, and quality equally good or better. Matures medium early. See preceding page.

GOLDEN BANTAM. Small, medium early, kernels yellow and of fine quality. We have a fine purebred strain of this corn which is far superior to

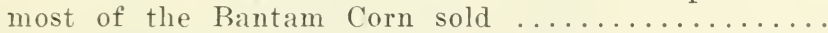

HOWLING MOB. Large 12 to 14 rowed ears, medium early and of good quality. A popular market corn

Metropolitan. Medium early, large ears, prolific and a profitable corn for market; quality first-class........

Crosby's Early. Medium early, very prolific, and of good

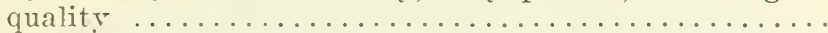

Potter's Excelsior or Squantum. Medium late, large ears of finest quality. A very fine corn for market and

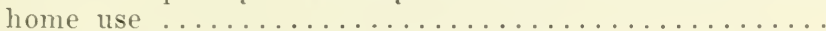

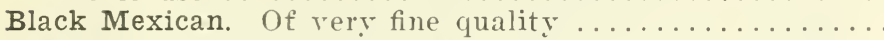

HICKOX IMPROVED. Very large ears, longer than (peck) $100 \mathrm{Lbs}$. $\$ \quad .35$ $\$ 3.25 \$ 26.00$

16.00

2.00 16.00

13.00

13.00 Evergreen and earlier than that variety and of finer

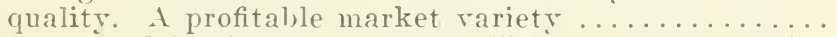

EARLY MAMMOTH. Earlier than late Mammoth, with immense ears. Matures with Evergreen and has much larger ears

LONG ISLAND BEAUTY. A late corn with immense ears, often orer is foot long and 7 to 9 in. around, 16 and 20 rows of pure white kernels that are of fine quality. A profitable late market corn

1.60

12.00

Burpee's White Evergreen. A very fine strain of Evergreen eorn with larger ears which are rery white and attractive in alpearance. Matures late $\ldots . . . \ldots .$.

Early Evergreen. Alout a week earlier than Stowell's.

STOWELL'S EVERGREEN. The standard late corn. We have a very fine strain grown in this neighloorhoorl that is earlier and better than western grown seed...

Country Gentleman. Late; small ears, of fine quality .

\section{POP CORN}

White Rice. The hest and most popular variety for market RED BEAUTY. Medium size ears, deep red, rery pro. 


\section{Harris's Perfection Cucumber (Photograph) CUCUMBER-Harris' Perfection}

This variety has been selected for manr rears with the idea of getting a cucumber as near perfection as possible. The fruit is long, straight, smooth and handsome. The color is deep green with clear white rars on the blossom end. The cucumbers retain this deep green color longer than any kind we know of. The fruit will average over a foot long when matured and many reach 15 inches in length.

The vines are vigorous and resist blight well. This is a White Spine variety and is one of the very best of this class. The fruit matures as early as the short kinds and are far superior to them. Our seed is so carefully bred that practically every cucumber is of almost perfect shape. See price below.

\section{CUCUMBER}

DAVIS' PERFECT. A carefully selected strain of White Spine, long straight fruit, tapering at both ends, very dark green and holds its color well.

HARRIS' PERFECTION. The finest type of White Spine for open ground or forcing. Long, deep green, and

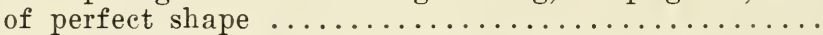

Irondequoit Hothouse. For forcing. See next page ......

Earliest of All. An extra early strain of White Spine. While shorter than later kinds, the fruit is longer and of better quality than any extra early cucumber we

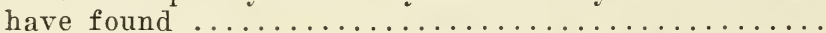

Fordhook Famous. A good variety of the White Spine class. Fruit very large but of lighter green than

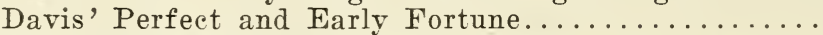

Arlington White Spine. Of medium length, very early and of good shape and deep green color. One of the very

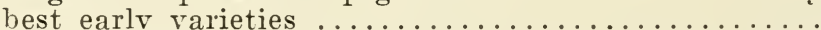

EARLY FORTUNE. A new and very fine strain of White Spine. It is early and very productive, excellent for market and pickles. The fruit is 8 to 9 in. long, slightly tapering and of deep green color. It holds its color

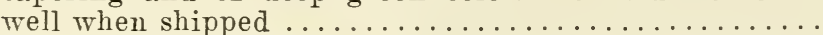

EARLY WHITE SPINE. Early and very productive. Excellent for pickles as well as slicing ............

Extra Long White Spine. A little later than Early White

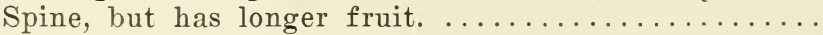

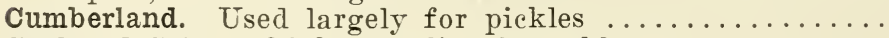

Cool and Crisp. Of fine quality for table use ...........

EMERALD. Long, smooth cucumber of the richest deep green. One of the handsomest and best varieties....

IMPROVED IONG GREEN. Very popular for both table use and for pickles. The strain we offer is very fine, the fruit being uniformly long and straight.....

Chicago Pickling. Short but very prolific and profitable for

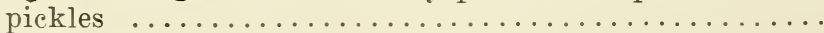

Perfected Jersey Pickle. Longer and more slender than Chicago and Boston Pickling. An excellent variety..

KLONDIKE. A popular variety for pickles. Dark green, straight and very prolific

Green Prolific or Boston Pickling. Very prolific short green fruit. A profitable variety for pickling.......

Early Green Cluster. Short fruit produced early and great

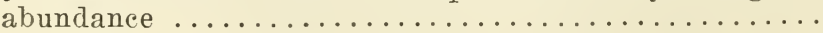

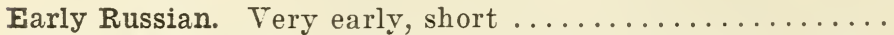

Everbearing. Starts bearing early and continues a long

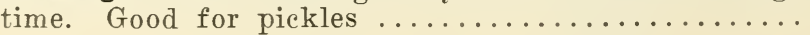

$\mathrm{Oz}$.

$1 / 4 \mathrm{Lb}$.

Lb.

$\$ .12$

$\$ .30$

$\$ 1.00$

.12

.12

.10

.12

.12

.15 
Japanese Climbing. A vigorous grower, long, smooth fruit

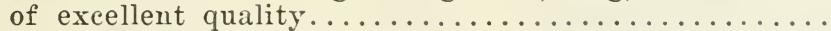

White Wonder. The fruit is pure white when young, about

$8 \mathrm{in}$. long and $2 \mathrm{in.}$ through and of fine quality........

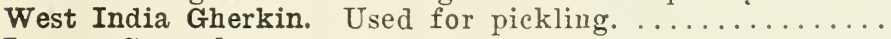

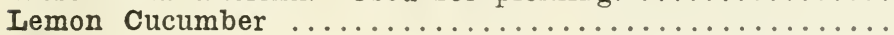

Oz. $\quad 1 / 4 \mathrm{Lb}$.

$\$ \quad .12$

$\$ .35$

$\mathrm{Lb}$.

.15

.18

.25

$\$ 1.25$

cOTE. We do not sell half ounces unless the price per ounce is $30 \mathrm{c}$ or orer.

\section{IRONDEQUOIT HOTHOUSE CUCUMBER}

The gardeners around Rochester have developed a very fine hothouse cucumber that has proved the most profitable variety to raise under glass.

The fruit is long, slender, deep green and nearly perfectly solid, there being very few seeds, and in some fruit none at all.

The vines are wonderfully vigorous and very prolifie.

The seed we offer was saved entirely from fruit grown under glass. Packet of 50 seeds 60 c; 100 seeds $\$ 1.00 ; 500$ seeds $\$ 4.00$.

Large Round-leaved

CORN SALAD or Fetticus Oz.

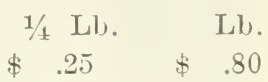

\section{DANDELION}

Large Thick-leaved. Much superior to the common variety

Much superior to the common

2.00

8.00

\section{DILL}

Used for flaroring pickles

.08

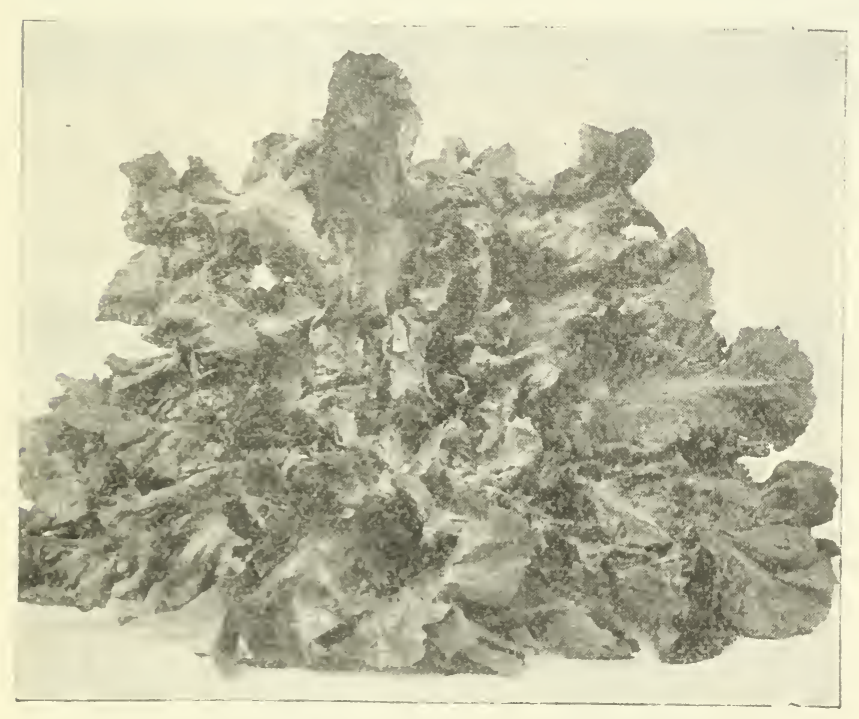

Broad-Leaved Batavian Endive

GREEN CURLED. Large leares finely cut and curled...

Moss Curled. Finely cut and curled; not so large as Green

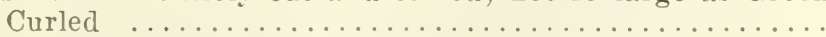

Broad-leaved Batavian (Ecarolle)

\section{ENDIVE}

Seed can be sown any time from early spring to August 1 , in the Northern States. For late fall market sow in July. Sow in rows 18 to $20 \mathrm{in}$. apart and thin the plants to a foot apart. To blanch tie up the leaves with soft cord or raffia. It requires about 20 days to blanch thoroughly in cool weather. Green Curled is the most popular market variety. Broad-leaved Batavian is also in good demand. "French Endive"' is Witloof Chicory and is quite distinct from True Endive, and its culture is entirely different.

$\begin{array}{rcr}\mathrm{Oz} . & 1 / 4 \mathrm{Lb} . & \mathrm{Lb} . \\ .12 & .30 & .95 \\ & & \\ .12 & .30 & 1.00 \\ .12 & .30 & .95\end{array}$

\section{"FRENCH ENDIVE" - WITLOOF CHICORY}

This is a crop that can be grown during the winter in a dark place and at very little expense. There is a growing demand for "French Endive" in the markets of all the large cities.

Directions for culture will be sent to any one interested without charge.

Seed. Pkt. 10c; 0z. 35c; 1/4 lb. 90c; 1b. \$3.25.

\section{Roots for Forcing}

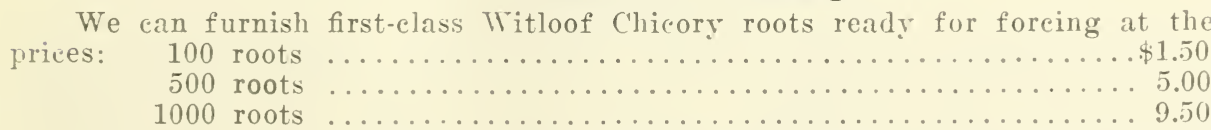

These roots can be shipped any time after December 1st. Forcing should commence in December and continue all through the winter. Order roots early. They can be kept in any cold cellar. Freezing does not hurt them if they are rovered with a little sand. 
EGG PLANT

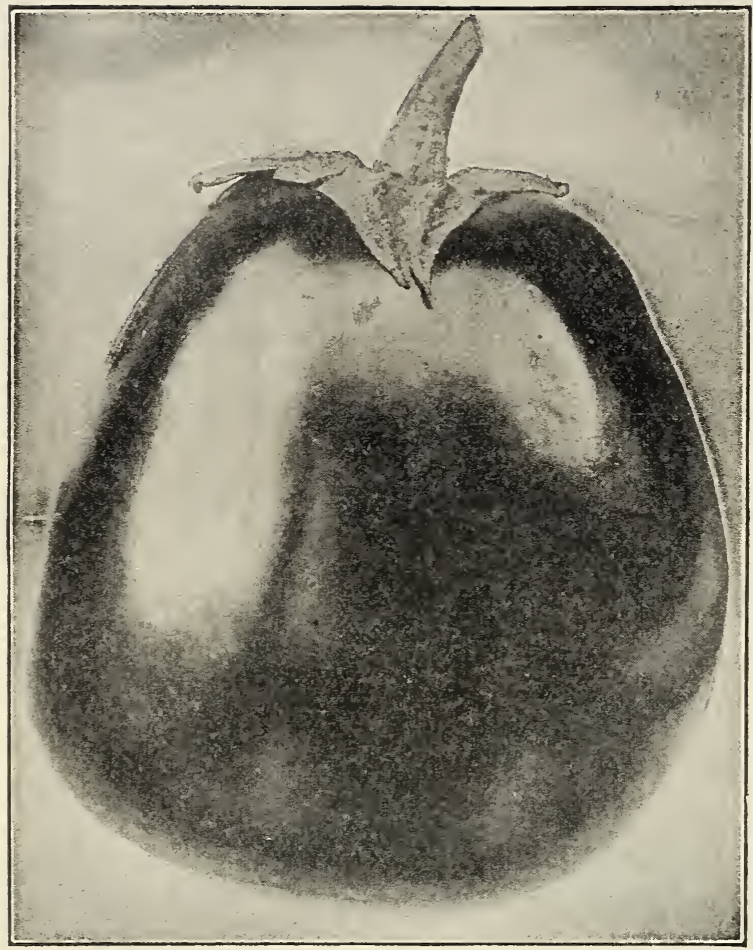

Black Beauty Egg Plant
Black Beauty produces fruit of good size and of deep purple color, and is the most popular market variety. New York Improved is very similar, but the plant grows a little taller and the fruit matures a little later.

Oz. $1 / 4 \mathrm{lb}$. Lb.

B la ck B e a ty.

Large, hand-

some, dark pur-

ple fruit, almost

black. It ma-

tures early and

is the most pop-

ular variety ....

New York Improved (Thorn-

less.) The stand-

ard variety .....

Purple. Very

early and prolif-

ic, but not as

large as above

kinds .........

E'ly Long Purple.

Fruit 10 to 12 in.

long, over 2 to 3

in. through, deep

purple and of

high quality.

Matures early

and is very pro-

lific ............

\section{$\begin{array}{lll}40 & 1.25 & 4.75\end{array}$} $40 \quad \ldots \quad \ldots$

\section{FENNEL}

Florence. Forms a large bulb which is excellent when cooked. Oz. $15 \mathrm{c}, 1 / 4$ lb. $40 \mathrm{c} ; 1 \mathrm{lb}$. $\$ 1.40$

\section{KALE}

Used principally in the late fall and early winter. Sow seed in July and treat like cabbage.

Dwarf C u r l ed

$$
\text { Oz. } 1 / 4 \mathrm{lb} \text {. Lb. }
$$

Green. Very

finely curled

leaves, of

dwarf spread-

$\begin{array}{llll}\text { ing growth... } & \$ .10 & \$ .25 & \$ .85\end{array}$

T a 11 Scotch

Curled. Grows

two feet tall.

$\begin{array}{lll}.10 & .25 & .85\end{array}$

Siberian. Called

also Sprouts.

Dwarf spread-

ing $\mathrm{b}$ road

leaves curled

only on the

edges. Very

hardy $\ldots \ldots . . .10 \quad .25 \quad .90$

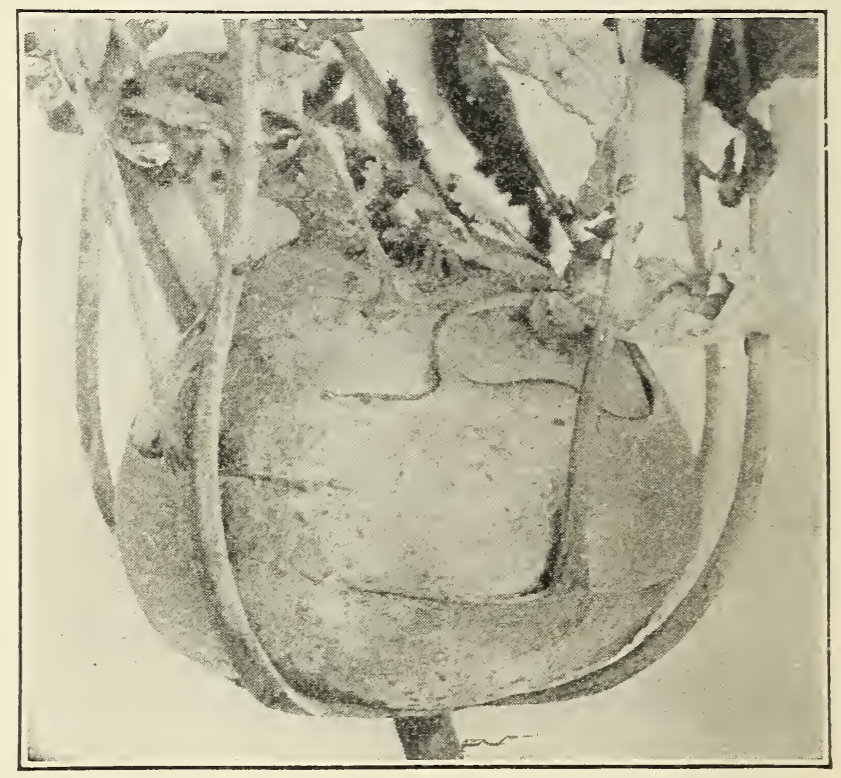

\section{KOHL RABI}

In some markets there is a good demand for Kohl Rabi. It is raised the same as turnips, but the seed should be sown in rows and the plants thinned to a foot apart. White Vienna is the best market variety.

Large Green. Used for stock feeding .12 $1 / 4 \mathrm{Lb}$.

$\mathrm{Lb}$.

Early White Vienna. The best variety for table use very early and can be used 10 weeks after sowing.........

Early Purple Vienna. Differs from White Vienna only in the color of the bulb which is light purple........... 


\section{LETTUCE}

For forcing May King is an excellent head variety. It will stand more heat than Big Boston, and matures quicker. Big Boston is fine for cool houses and cold frames. For a curl leaf lettuce Grand Rapids is hy far the most popular. Grows rapidly and the leaves stand upright so can be planted rlose.

For summer planting in the open ground, Iceberg, Unrivaled, Salamander, Holyrood Hot-Weather and Deacon are good. Big Boston is most lergely grown on muck land for both early and late crops.

Romaine or Cos Lettuce can be grown both in the hothouse and open ground and is in good demand in many markets. Trianon Self-Folding is the largest kind; the heads often being nearly a foot high. Eclipse is shorter and forms the head earlier. Both do best in cool weather.

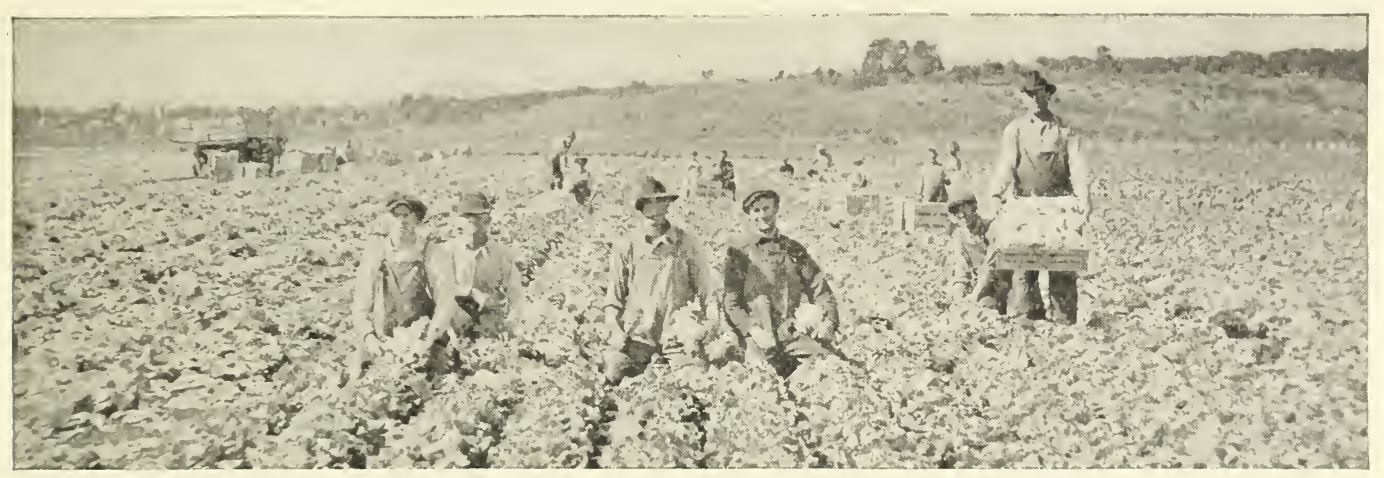

Harvesting Harris' Selected Big Boston Lettuce on the Gardens of J. H. Snyder, Sodus, N. Y.

\section{SELECTED BIG BOSTON LETTUCE}

Our strain of this lettuce is exceptionally fine. Heads uniformly solid and compart, and stand a long time without bolting. Some of the largest growers in this county are using Harris' Big Boston and find it equal if not superior, to any other stock obtainable at any price. Oz. $12 \mathrm{c} ; 1 / 4$ 1b. $35 \mathrm{c} ; 1 \mathrm{~b} . \$ 1.25 ; 5 \mathrm{lbs}$. or more $\$ 1.20$ per $1 \mathrm{~b}$.

Mr. F. M. Hull, Red Creek, N. Y., writes:

"The Big Boston Lettuce I received from you this spring was the best I ever had. ()nly one plant not true to name in the whole piece.

Mr. Roy L. Smith, a large grower at Cato, N. Y., writes:

- I sowed two acres with your Big Boston last fall and every one that saw it said it was the finest piece of lettuce they ever saw. It was the finest I ever raised."

$M_{1}$. MI E. Kerwin, an extensive lettuce grower of South Linma, X. Y., writes:

Your Big. Boston lettuce has done fine for me. About 50 members from Cornell Iniversity were in South Lima one day last summer and they told me your lettuce was the nicest stock they had seen there."

"Your Big Boston was the finest I ever grew. There was no lettuce like it on the market." I. Kreigsmann, Elizabeth, N. J.

MAY KING. A very early head lettuce for open ground

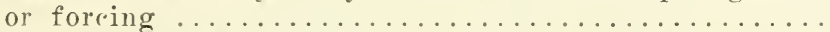

HOLYROOD HOT-WEATHER. Large, firm heads. Stands well in the summer and is very slow to run to seed....

BIG BOSTON. Used largely for foreing and open ground on moist soil

Oz. $\quad 3 / 4 \mathrm{Ll}$.

Lb.

SALAMANDER. Large heads, light green; stands well in

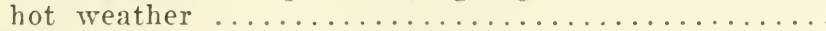

UNRIVALED. Like Big Boston, but lighter green and without the red tinge; stands hot weather better and heads earlier. A fine summer variety. Called also "'Long Lost," "'Green Leaved Big Boston," "Cabbage Head Giant,' and a dozen other names.

Deacon. Large heads. smooth leares, of finest quality.

WONDERFUL or NEW YORK. Very large firm heads;

$\begin{array}{cccc}\$ .12 & \$ & .35 & \$ 1.20 \\ .12 & .35 & 1.25 \\ .12 & .35 & 1.25 \\ .12 & .35 & 1.20 \\ & & \\ .15 & & .40 & 1.50 \\ .12 & .35 & 1.25\end{array}$

almost as large as Wakefield cabluge. We have a very fine strain. This is the "Jcelerg", lettuce grown on the West coast and shipped to onr Eastern market during the winter

ICEBERG. One of the best for open ground. Large, firm heads, curled and blistered leaves. Our strain is very fine

Prize Head. Early, crisp, loose loarls of goorl ryuality; leaves curled and tinged with redlish brown. 
CRISP AS ICE. Forms compact, medium, small heads very early. The heads are tinged with deep brown and the

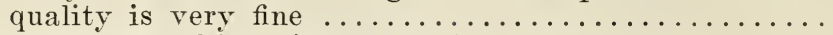

Grand Rapids. Of upright growth. Curled leaves. Valuable for forcing. Our strain is very fine ...........

Golden Queen. Compact head, light color. A popular varie-

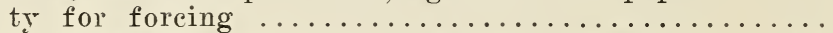

Boston Market. A small heading lettuce used for forcing

Hanson. Large heads of fair qualit5...............

TOMHANNOCK. Very large, loose heads, eurly leaves

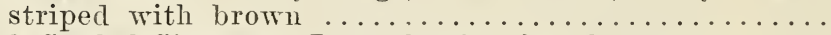

Black Seeded Simpson. Loose heads of curly leares; grows

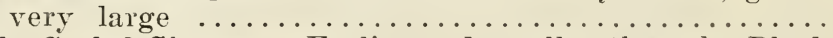

Early Curled Simpson. Earlier and smaller than the Black

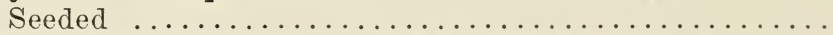

COS or ROIMAINE, Trianon Self-Folding. Used for foreing and open ground. Large, long heads of fine

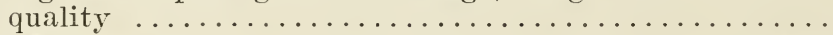

Cos, Eclipse. Forms compact heads very early. A valuable variety for forcing as well as the open ground. Every

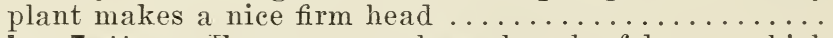

Chicken Lettuce. Forms a very large bunch of leaves which

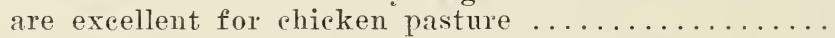

$\begin{array}{llll}.12 & \$ & .35 & \$ 1.25 \\ .12 & & .35 & 1.20 \\ .15 & & .40 & 1.50 \\ .12 & & .35 & 1.20 \\ .12 & .30 & 1.10 \\ .12 & .35 & 1.20 \\ .12 & .30 & 1.10 \\ .12 & .35 & 1.20 \\ .12 & .35 & 1.25 \\ 1.5 . & .40 & 1.50 \\ .12 & .30 & 1.10\end{array}$

\section{LEEK}

Large American Flag. The most popular variety.......

\section{MUSKMELON or Cantaloupe}

Nearly every market wants a different muskmelon. Rocky Ford and Paul Rose are probably the most popular in many markets, and are excellent melons for shipping. Admiral Togo is an improved variety of this class and better than the older types. Hoodoo or "Hearts of Gold"' is another good one of this class; small, firm, heavily netted and deep yellow flesh of high quality. Osage is in demand in some cities and is a large, handsome, round melon of high quality and good for near-by markets. Bender's Surprise is now the most popular of the large nelons. It is very firm and keeps a long time after picking and is of the highest quality. Emerald Gem is small, but very early and of high quality. It is not good for shipping.

IRONDEQUOIT. Large, round, netted; yellow flesh. A fine

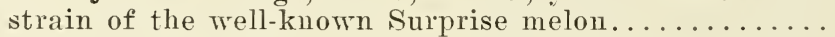

BENDER'S SURRISE. A grand melon. See description

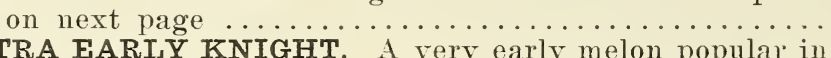

Oz. $\quad 1 / 4 \mathrm{Lb} . \quad \mathrm{Lb}$. $.20 \quad .55 \quad 2.00$

EXTRA EARIY KNIGHT. A very early melon popular in
markets where known. The fruit is of medium size. oval in shape and well netted. The flesh is green and

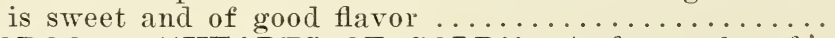

HOODOO or "HEARTS OF GOLD" A fine melon for shipping in baskets-small, round and well netted. Flesh orange yellow and of high flavor. Very firm and holds up well for a long time after picking...........

ADMIRAL TOGO. Oval, netted; flesh yellow and of finest flavor. Very prolific, medium size, slightly larger

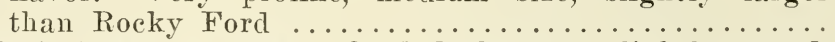

Miller's Cream, or Osage. Oval, dark green, slightly netted, yellow flesh of fine flavor: A very fine melon and a

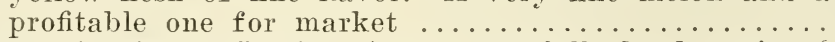

OSAGE, Perfected Strain. A very carefully bred strain of Osage melon which is 10 days earlier than the old type and the fruit is almost as large and is more uniform in shape and quality. This is a fine melon and will prove very profitable on account of its earliness and fine

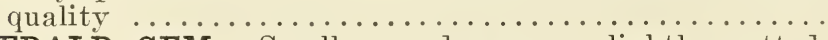

EMERALD GEM. Small, round, green, slightly netted. yellow flesh of finest flavor; very early and prolific....

PAUL ROSE. Fruit of medium size, oval netted and very firm. Flesh orange yellow and of high quality. A ralu-

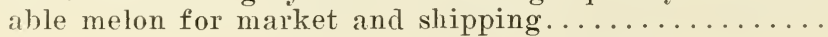


ROCKY FORD (Netted Gem.) Small, oral, netted, green flesh

$\mathrm{Oz}$.

$\$ .10$

$1 / \mathrm{Lb}$

Lb.

DELICIOUS GOLD-LINED ROCKY FORD. A very fine improved strain of the Rocky Ford melon. The flesh is green but has a yellow tinge about the seed cavity.

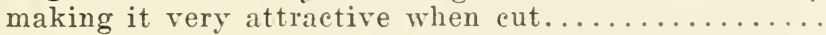

Hackensack. The standard, large netted, green flesl melon

Honey Dew. A melon that will keep two months after picking. It is shipped to eastern cities from California and the Southwest where it does well. It does not suc-

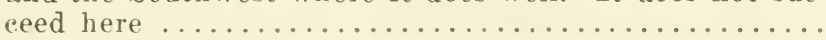

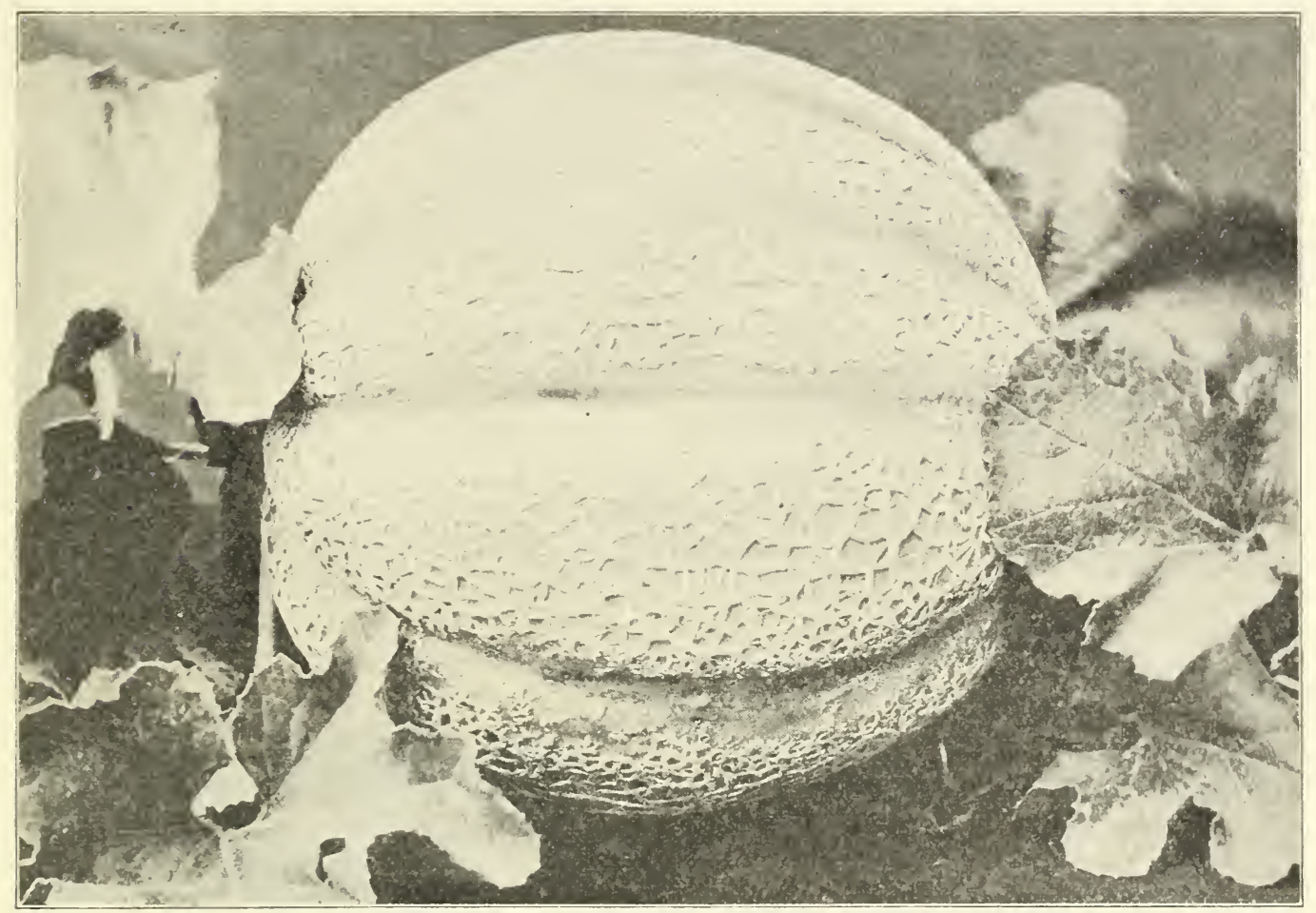

\section{BENDER'S SURPRISE MUSKMELON}

\section{A Grand Melon for both Shipping and the Home Market}

We have raised muskmelons for many years, but have never seen a melon quite equal to the Bender in fine flavor, size and keeping qualities combined.

Mr. Bender's melons have a wide reputation for high quality among eluls and the best hotels. The seed was never offered by any dealer for a long time, but the public now has an opportunity to get seed that is of the genuine Bender strain which we have grown and selected for five years.

The melons are round to oval in shape, ribbed and partly covered with netting. The Hesh is very thick, especially so at the blossom end so that the melons rarely crark.

When ripe the melons turn a golden tint which shows through the netting and gives the fruit a very attractive appearance.

The size of the melons averages quite large, many weighing lo lhs. and more. We have had melons that weighed 16 pounds.

A valuable point about these melons is that they will keep in good condition five or six days after picking, and actually improve in flavor during that time. The flesh is sc: firm and thick that the melons remain firm and in good condition much longer than other large melons of this class. For market and shipping this is an important consideration.

We offer seed of our own growing and from melons of the highest quality. The quantity of this high grade seed is quite limited. We arvise early orders. $0 z .45 \mathrm{c} ; 1 / 4.1 \mathrm{~b}$. $\$ 1.35$; 1b. $\$ 5.00$. 


\section{WATERIMELON}

Harris' Earliest, Cole's Early, and Ice Cream or Peerless are valuable for the North because they will ripen before frost.

For places south of New York City, Tom Watson and Kleckley Sweets are better because they are larger and of high quality.

HARRIS' EARLIEST. The earliest large melon of good quality. One of the best varieties for the North......

HALBERT HONEY. Long, dark green, flesh red and of

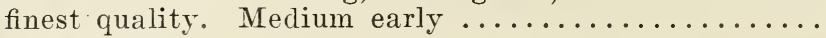

COLE'S EARLY. Very early and of good quality........

Irish Gray. Long, light green, very large with a tough shell and firm bright red flesh of fine quality............

TOM WATSON. The most popular melon for shipping. Fruit long, medium green with lighter markings. Rind strong so the melons stand shipping well...........

KLECKLEY SWEETS. Long, deep green, attaining a large size and of fine quality. One of the best kinds. Our Northern grown seed is superior to Southern grown. Seed saved from the best melons only ..............

Mountain Sweet. A large, medium early melon............

Ice Cream or Peerless. One of the best early varieties. Large, light green, early and of fine quality.........

HUNGARIAN HONEY. Small, round, dark green, with bright red flesh of delicious sweetness..............

GREEN CITRON, or Colorado Preserving. (Green seeds.)

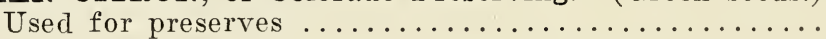

$\mathrm{Oz}$. $1 / 4 \mathrm{Lb}$.

Lb.

$\$ .10$

.10

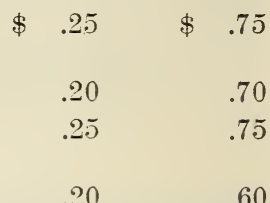

.06

.06

.06

$$
.15
$$

.20

.60

\section{MUSTARD}

FORDHOOK FANCY. Finely cut and curled leaves, very

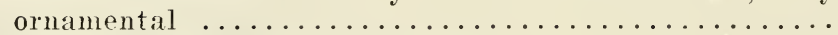

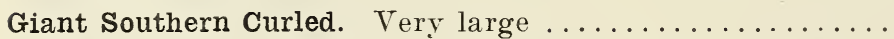
White London. The seed is used for flavoring pickles....

\begin{tabular}{|c|c|c|c|}
\hline .12 & $\$$ & .25 & $\$$ \\
\hline .08 & & .20 & \\
\hline .08 & & .15 & \\
\hline
\end{tabular}

\section{ONIONS}

Note.-Our Onion seed is all tested for germination before it is sent off, and the per cent. that germinates is marked on the label.

For market and storage a globe-shaped, yellow onion is usually preferred, although for some markets a red onion sells best. Yellow Globe Danvers is nearly round. Ohio Yellow Globe is slightly flattened on the bottom, and Southport Yellow Globe is more pointed at the bottom, forming an oval shape rather than perfectly round. These are the typical shapes for the different strains as they are supposed to be, but of course there are some onions of all these shapes in any of these different strains. The Danvers and Ohio strains are a little earlier than the Southport and are the most popular varieties. Round Yellow Danvers is flatter than the Globe and matures earlier. Prizetaker is larger than the Globe Danvers and a little later.

For pickles Early Barletta is best. The seed should be sown very thick so the onions will be small and the yield heavy.

Special prices will be quoted on large lots of Onion Seed. Please write us stating what kinds and quantities you want.

YELLOW GLOBE DANVERS, Harris' Selected Strain.

Oz. $\quad 1 / 4$ Lb. Lb.

Our seed of this variety is grown from very carefully

selected bulbs, and will be found much superior to the seed usually sold. It produces bulbs of uniform globe shape, deep yellow color and with small tops.........

OHIO YELLOW GLOBE. A very fine strain of Yellow Globe Onion especially suited to muck land. The onions are globe shaped, but a little more flattened on the bottom than the Globe Danvers or Southport........

ROUND YELLOW DANVERS. Earlier and flatter than Globe Danvers 
SOUTHPORT YELLOW GLOBE. A ver fine strain of this onion grown from perfect globe-shaped bulbs of

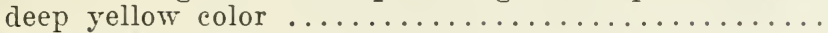

PRIZETAKER. Large yellow onion of very handsome globe shape and mild flavor. Does not keep as well as Dallvers. Fine for fall market ..................

SOUTHPORT RED GLOBE, Harris' Special Selected. Large, perfectly round, deep red onion; keeps well and is the best red varietr. Our seed is raised from carefully selected onions and will be found very fine.....

Early Large Red. Large, flat, red onion. Matures early

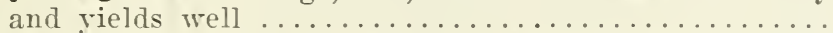

LARGE RED WETHERSFIELD. Tery large deep red,

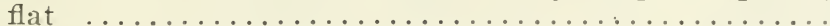

Southport White Globe. The largest and finest white onion. The seed we offer is of extra fine strain ............

EBENEZER. A very fine round, yellow onion that will keep all winter and is of mild, pleasant flavor. The seed is used principally for raising sets, which when set out the following spring produce large, handsome ripe onions in July. Our seed was raised by one of the original growers and is the genuine Ebenezer.......

Australian Brown. Will keep the vear around: matures early. The onions are flattened, of a golden brown

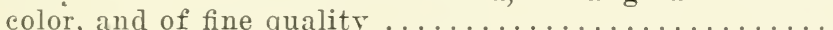

WHITE PORTUGAL, or SILVER SKIN. Flat, white onion of mild flavor, early. Excellent for pickling.......

EXTRA EARLY BARLETTA. The best small white onion

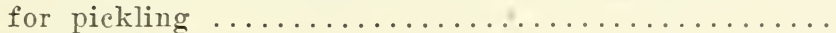

GIANT GIBRALTAR. This is the largest Spanish onion which is sold in our markets. The onions are almost perfectly round or globe shaped, bright yellow and of very mild flavor. They grow very large, often weighing a pound or more. Matures rather late and should have plenty of room to develop. Genuine im-

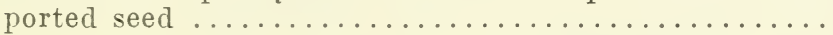

Oz. $\quad 1 / 4 \mathrm{Lb}$.

Lb.

$\$ .15 \quad \$ \quad .45 \quad \$ 1.60$

3.00

\section{ONION SETS}

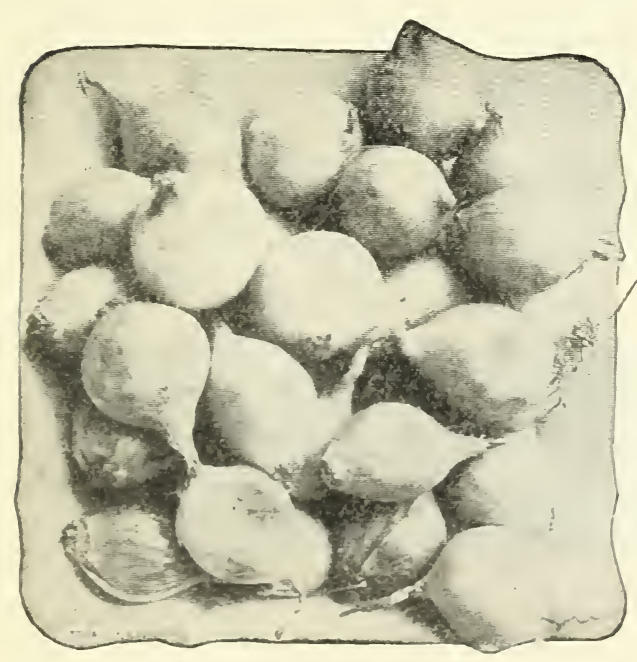

White sets make the whitest and most attractive bunching onions. The Yellow sets, especially the Ebenezer, are best to produce large dry onions for early use.

Yellow Sets. Sound and clean .............. .20 \$ $1.00 \$ 3.50$ White Sets. Sound and

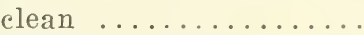

Ebenezer or "Japanese"

$$
.25 \quad 1.20 \quad 4.00
$$

Sets. These sets are the best to produce large ripe onions. They do not run up to seed. The onions are rather light yellow and of very mild

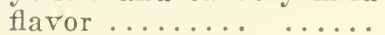

Note-Prices subject to change. Please write for price if a considerable quantity is required.

\section{OKRA or GUMBO}

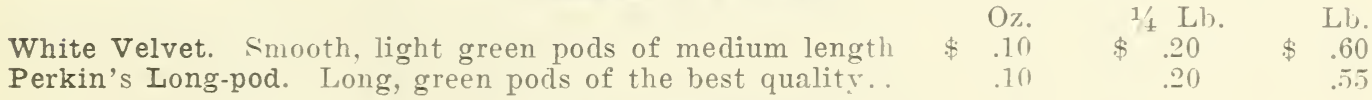

\section{PARSNIPS}

HARRIS' NEW MODEL. Smooth, rerr white roots of me diun length. Seed raised from transplanted and selected roots only

Long Hollow Crown. Long, smorth roots 


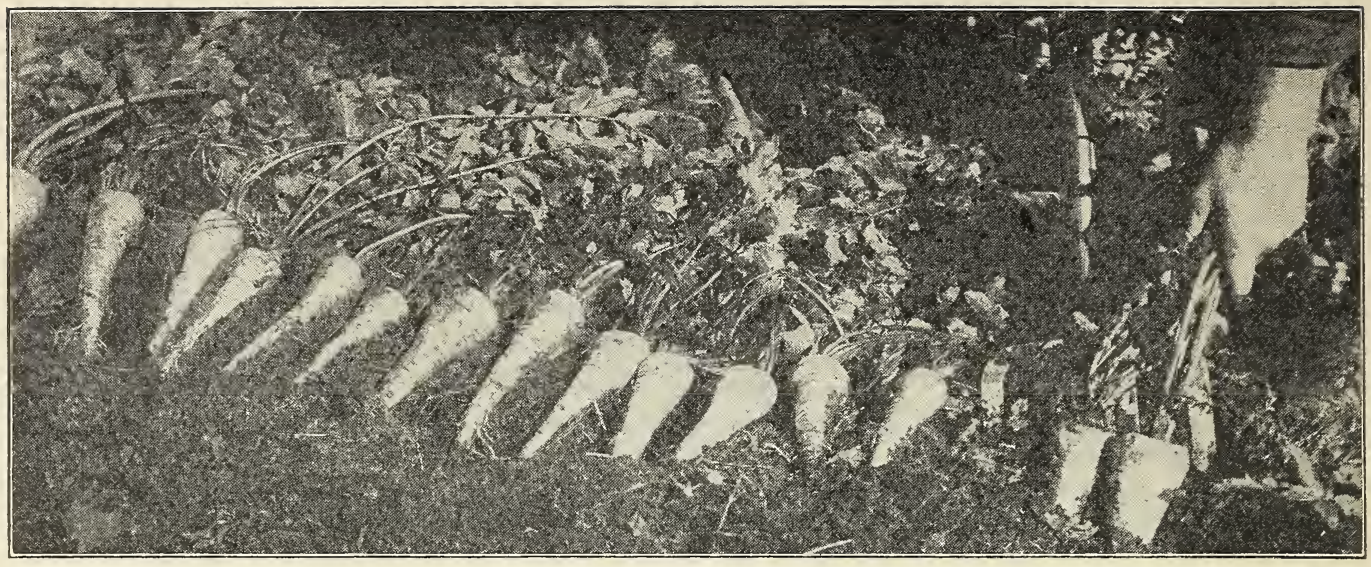

Harris' Model Parsnip-Every One a Model. Photographed Exactly as Dug.

\section{HARRIS' NEW IIODEL PARSNIP}

We have been improving the old Hollow Crown parsnip by careful selection for some years until we have obtained a very fine strain which we eall "Harris' Model." The shape is shown in the photograph above.

The parsnips grow to a good length, but not too long. The roots are smooth, snow white, and have practically no side roots or prongs. Their whiteness is quite remarkable and gives the roots a very attractive appearance.

Our seed is grown from transplanted and very carefully selected roots and it will be found far superior to the seed usually sold. Oz. 15c; 1/4 lb. 40c; lb. $\$ 1.50$.

From a very extensive gardener.

"I want Harris' Model Parsnip seed the same as you sent me last year. It is as fine as silk." -Del Titus, Irondequoit, N. Y.

"Your New Model Parsnips are head and shoulders above everything else. I have used your seeds for a number of years and they beat any seeds I obtained elsewhere, and I have used seed from all the leading Easterr seedsmen."-L. W. Brotzman, Broome County, N. Y.

\section{PARSLEY}

DWARF PERFECTION. The finest parsley we have ever seen. Dark green and very finely curled............ Champion, or Triple Moss Curled. Finely curled deep green

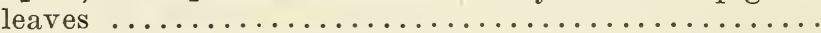

Extra Double Curled. Not quite as fine as the above.....

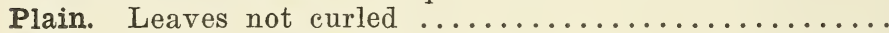

Turnip-rooted or Hamburg. Form large roots that are cooked as a vegetable. We have a fine variety called "Thick Sugar" with smooth white roots of the best quality. Far superior to the common variety in both

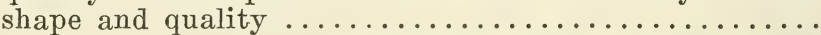

$\begin{array}{rrr}\text { Oz. } & \text { 1/4 Lb. } & \text { Lb. } \\ \$ .12 & \$ \$ .30 & \$ 1.10 \\ & & \\ .10 & .25 & .75 \\ .08 & .20 & .70 \\ .08 & .20 & .70\end{array}$

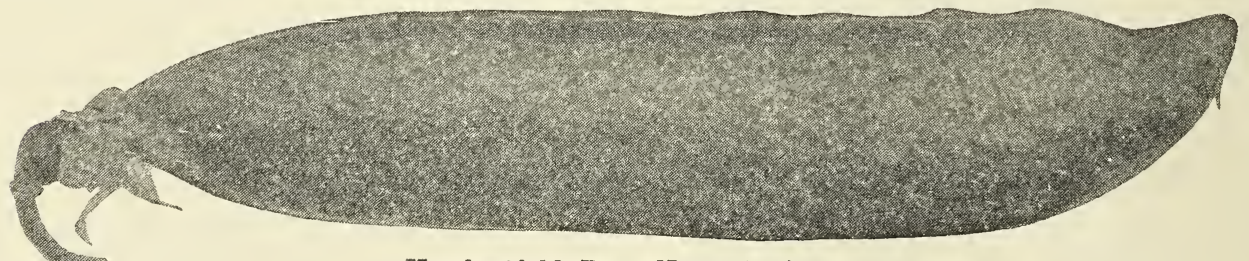

Hundredfold Pea-Natural Size

PEAS

The very earliest peas like Alaska and Surprise have small pods, but Thomas Laxton Acquisition and Gradus are only three or four days later and have much larger pods. Laxtonian and Hundredfold are two or three days later than Gradus and have larger pods. Little Marvel matures a day or two earlier than Sutton's Excelsior and produces wonderful crops, but the pods are not as large, being about the size of Nott's Excelsior.

Duke of Albany and Alderman are strains of Telephone, but are better than the old type, having darker colored peas and large pods. Heroine is later and has long pods and is very prolific. Prizewinner is a little later than Telephone, has short heavy vines and very large deep green pods, and is one of the best late varieties.

Horsford's Market Garden is a great bearer, but the pods are rather small for market. Long Island Mammoth has very large pods, matures late and is not of as high quality as Telephone, which the pods resemble. 


\section{A Valuable New Pea.-Acquisition}

This new pea is as early as Thomas Laxton and Gradus and has much larger pods. This makes it a profitable market variety. The vines are $21 / 2 \mathrm{ft}$. high and produce large crops. See price below.

NOTE-We are now selling peas by weight only. A pound is about 1 pint, 15 lbs. equa a peck and $56 \mathrm{lbs}$. a bushel by measure. Any quantity over $30 \mathrm{lbs}$. will be supplied at the $100 \mathrm{lb}$. rate.

\section{Early Varieties}

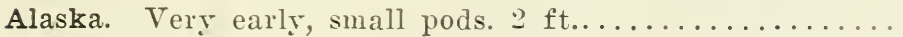

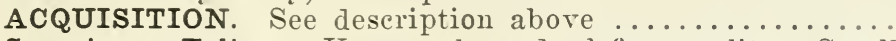

Surprise or Eclipse. Tery early and of fine quality. Small

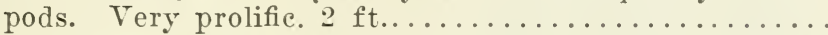

First and Best. Extra early; pods three inches long, well

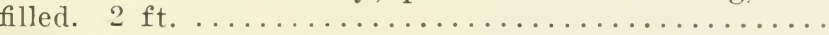

THOMAS LAXTON. Tery early; medium-sized pods. One of the most profitable market peas. Our stock is very

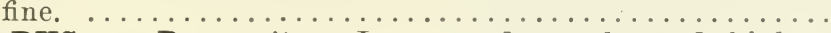

GRADUS, or Prosperity. Large pods, early and highest

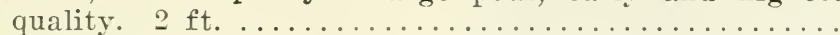

LAXTONIAN (Pioneer). A dwarf pea with pods as large as Telephone and matures as early as Little Gem. Pods

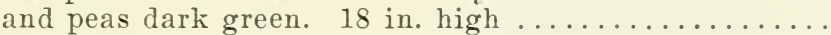

HUNDREDFOLD. Much like Laxtonian but yields more. Vines very strong and sturdy, 16 to 18 in. high. Pods 4 in. long and deep green. Matures a day or two after

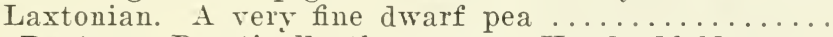

Blue Bantam. Practically the same as Hundredfold ......

LITTLE MARVEL. Tery prolific, matures a day or two later than Nott's Excelsior and has pods a little larger;

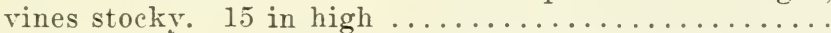

Nott's Excelsior. Early, dwarf vines, medium-sized pods; one of the best early dwarf peas. 15 in. high..........

SUTTON'S EXCELSIOR. Larger pods than Nott's and only a day or two later. A valuable variety. $18 \mathrm{in.} \mathrm{high}$

McLean's Little Gem. The standard early dwarf pea. 15 in. high

American wonder. Very dwarf, early 15 in. high.........

\section{Medium and Late Varieties}

Advancer. Pods three inches long, well filled; $a^{\circ}$ heavy

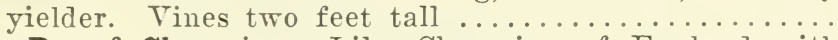

New Dwarf Champion. Like Champion of England with vines only two feet tall. Good large pods and very prolific. One of the best late peas with short vines. $2 \mathrm{ft}$.

Horsford's Market Garden. Very prolific; medium size pods; late. $2 \mathrm{ft}$.

Carter's Daisy or Dwarf Telephone. Similar to Telephone except that the vines grow only 20 inches tall.

DUKE OF ALBANY. An improved Telephone with dark green pods well filled; called in some localities "Dark Telephone', $4 \mathrm{ft}$.

ALDERMAN. Pods larger than Telephone and much better filled. One of the very best, if not the best pea of the Telephone class. Pods often 6 in. long and of deep green color. tft.

Telephone. Our seed is of a superior strain, having large pods of very deep green. $4 \mathrm{ft}$.

HEROINE. Very fine pea with long pods well filled. A profitable late market sort of best quality. $2 \frac{1}{2} \mathrm{ft.}$.

Champion of England. The standard tall, late pea. $t^{1} / 2 \mathrm{ft}$.

IMROVED STRATAGEM. Large pods, stocky vines, $2 \mathrm{ft}$. tall. A very fine late market pea of highest quality.

PRIZEWINNER. A new variety of the Stratagem type, but is much more productive. Vines $2 \frac{1}{2} \mathrm{ft}$. tall, very sturdy and produce great crops of large deep green pods. A

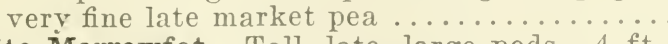

White Marrowfat. Tall, late, large pods. $4 \mathrm{ft}$.

Mammoth Melting Sugar. Edible pods, $4 \mathrm{ft}$.
(Bu.)

Lb. $15 \mathrm{lbs}, 56 \mathrm{lbs} .100 \mathrm{lbs}$

$\$ .22 \$ 2.25 \$ 7.84 \$ 14.00$

$\$ 19.00$

$\begin{array}{llll}2.5 & 2.55 & 5.96 \quad 16.01\end{array}$

$.25 \quad 2.40 \quad 8.40 \quad 15.00$

$2.55 \quad 8.96$

16.01

$\begin{array}{llll}25 & 2.55 & 5.96 & 16.00\end{array}$

2.55

5.96

$16.0 n$

.25

2.70

9.52

$2.70 \quad 9.52$

17.00

17.00

$2.55 \quad 8.96$

16.00

16.00

$2.55 \quad 8.96$

16.00

2.55

8.96

16.00

$2.55 \quad 8.96$

16.00 


\section{'HARRIS' EARLIEST' SWEET PEPPER THE EARLIEST AND MOST PROLIFIC SWEET PEPPER}

Gardeners who have trouble getting peppers that will produce a good crop of fruit early enough for the Northern States should try Harris' Earliest.

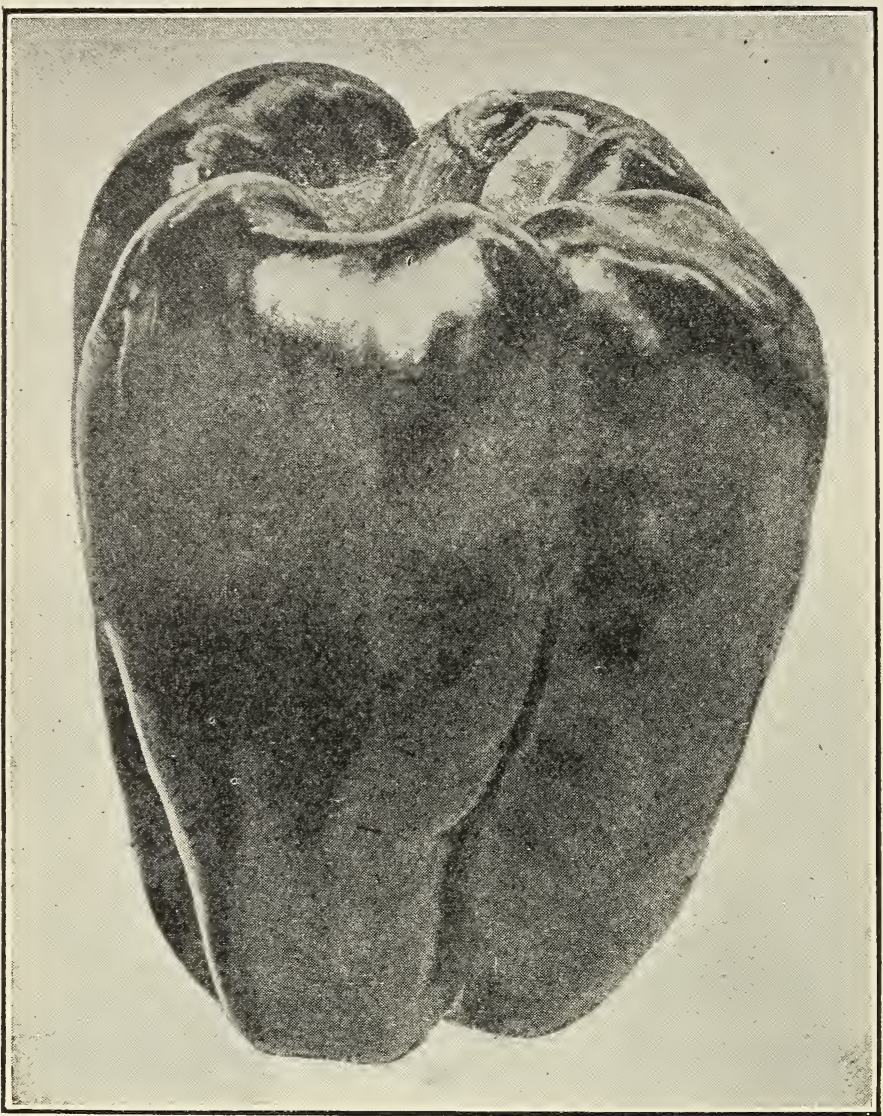

“'Harris' Earliest"' Sweet Pepper (Photograph Actual Size)

This is by far the earliest sweet pepper we know of. The fruit is of good size, resembling the Large Bell or Bull-Nose (but unlike that variety is mild and sweet.) The peppers are bright red when ripe and very firm.

The plants are of dwarf, compact growth and are literally covered with fruit, there being often a dozen large ripe peppers on a plant at one time and many green ones.

They can be set out closer together than other varieties and an immense number of peppers are produced on a small amount of land.

It always produces lots of fruit and is so early that the fruit gets ripe long before frost. With this new kind you can get peppers on the market before any other growers have them.

We are improving the size and shape of this pepper every year. It is now much larger and of better shape than it was two or three years ago.

Some gardeners tell us that we do not say enough about this pepper. They say they get more peppers from 100 plants than from 500 of any other kind that bears sweet peppers.

Seed of our own growing. $1 / 4$ oz. $25 \mathrm{c} ;$ oz. $75 \mathrm{c} ; 1 / 4$ lb. $\$ 2.75 ; 1 b . \$ 10.00$

\section{WHAT MARKET GROWERS SAY}

'Harris' Earliest peppers have been a veritable gold mine and I have never been able to make any other variety produce in this locality." L. E. Johnson, Richfield Springs, N. Y., Sept. 21, 1921.

"Your seeds have done the best for me of any I ever bought, but you do not some quite strong enough in your recommends for the peppers. I have picked 18 good sized peppers at one picking from a plant of Harris' Earliest and still left a lot of small ones on the plant. They have got it over any pepper I ever saze for vield and flavor." 'W. J. Ingersoll, Angola, N.Y., April 7, 1921.

"The Harris' Earliest pepper I got of you is the earliest pepper I have ever seen. At this date, July 24th, the plants are loaded with large fruit and also full of bloom." John H. Withey, Skaneateles, N. Y.

\section{New Yellow Pepper-Oskosh}

This is by far the best yellow pepper we have seen. The fruit is large, very smooth, almost round, and the flesh is twice as thick as most other varieties and is remarkably sweet-more so than any pepper we know of. The green peppers are so smooth, firm. and heavy they are most desirable for stuffing.

The plant is very prolific and the peppers mature as early as any of the very large varieties. We advise gardeners to try at least a small quantity this vear. Packet 10c; oz. $90 \mathrm{c} ; 1 / 4$ lb. $\$ 3.50$.

\section{IIAGNUIM DULCE PEPPER}

This is the largest pepper we know of. It is even larger than Chinese Giant and much more prolific and earlier. If you want big peppers this is the kind to raise. The fruit is as broad as it is long, has thick flest and of very mild sweet flavor. The color is deep green turning to red when ripe. Oz. $50 \mathrm{c} ; 1 / 4 \mathrm{lb}$. $\$ 1.75 ; 1 \mathrm{~b} . \$ 6.50$. 


\section{PEPPERS}

Giant Crimson, Magnum Dulce and Chinese Giant are the largest peppers, but do not bear as well as the varieties with smaller fruit, such as Neapolitan and Harris' Earliest which are also earlier. Of the two, Giant Crimson is more prolifie and earlier than Chinese Giant with just as large fruit. Ruby King produces well and is a very large pepper, but somewhat late for the northern parts of the country. Harris' Earliest has fruit as large as Bull Nose and is earlier, more prolific and the fruit is mild and sweet. Of the pungent or "hot" peppers, Giant Cayeme is one of the best.

HARRIS' EARLIEST. See description preceding page.. Chinese Giant. Immense peppers that are mild and sweet

GIANT CRIMSON. As large as Chinese Giant, but earlier

$\begin{array}{rrr}\mathrm{Oz} . & 1 \text { L Lb. } & \mathrm{Lb} . \\ .75 & \$ 2.75 & \$ 10.00 \\ .50 & 1.60 & 5.75 \\ & & \\ .40 & 1.2 .5 & 4.75 \\ .30 & .75 & 2.50\end{array}$
and more prolifie. Tery mild and sweet. One of the best of the very large varieties .................

Ruby King. Large, sweet, bright red when ripe. Fruit $\bar{y}$

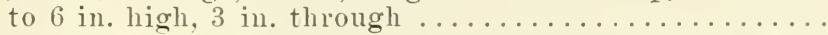

NEAPOLITAN. Tery early, medium size and mild. Tery prolific and profitable for market. Fruit $3 \frac{1}{2}$ to 4 in. high and 2 in. through. Rather light green when young, bright red when ripe. The fruit stands upright on the

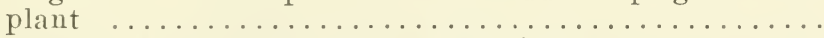

Sweet Mountain. Large fruit, $5 \mathrm{in}$. high and $3 \mathrm{in}$. across. Deep green turning to red. Mild and sweet...........

Large Bell or Bull Nose. Early, medium size, quite prolific,

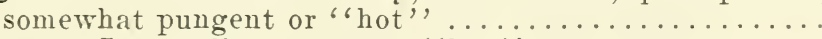

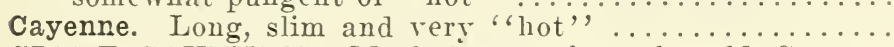

GIANT CAYENNE. Much larger than the old Cayenne and equally pungent. Fruit 3 to $4 \mathrm{in}$. long and $1 \frac{11}{2} \mathrm{in}$. through at top coming to a point at the bottom. Very

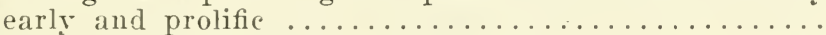

osKosH. The largest and best yellow pepper. See des-

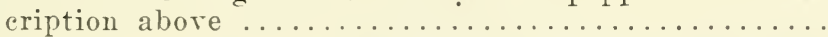

Golden Dawn. A fine yellow pepper. Large and sweet...

PIMIENTO. Tery thick, heary fruit of medium size pointed at the bottom. Tery deep green when roung, bright red when ripe. Of mild flavor. Matures rather late,

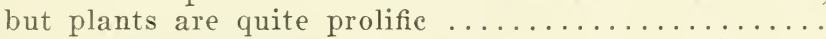

SQUASH OR TOMATO. Small round peppers the shape of a tomato. Tery prolific and the peppers are mild and

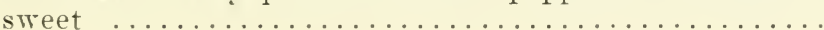

\section{POTATOES}

Disease-Free Seed. "Certified", potatoes are supposed to have not over $5 \%$ diseased plants. Our potatoes are raised from seed taken from the best hills only and the erops are carefully inspected and the few diseased plants are at once removed. Some of our crops showed practically no diseased plants at all, being very much better than crops from certified seed in the same field. (See our general catalogue.)

About Shipping.- The potatoes are shipped in sacks holding 150 pounds (21/2 bu.) or barrels holding 180 lbs. ( 3 bu.) We ean usually ship safely by the middle of March, but not before, except to the Southern States. If you wish them shipped in wooden barrels please add 45 e to the prices quoted.

If seeds and potatoes are ordered, please state on the order whether the seeds are to be held to go with potatoes, or to be sent at once, and the potatoes later when it is safe to ship them. We cannot safely ship potatoes until the last of March.

Prices subject to change.-The prices here quoted are subject to changes of the market and to our acceptance on receipt of order. Lowest prices will be quoted by letter at any time. Please state the kinds you are interested in.

Varieties.--Of the early kinds Early Six Weeks, Early Ohio and Bliss' Triumph are the earliest and are light pink in color. Irish Cobbler is a very early white potato. Green Mountain is medium late and of finest quality. Golden Rural or Rural Russet is one of the best late varieties.

BLISS' TRIUMPH. One of the very earliest varieties and a heavy vielder. The potatoes are round and of a handsome deep fink color

IRISH COBBLER. The most popular round white early potato. Our stock is rery fine, being pure and true to name. Grown from hill-

selected seed and practically disease-free......................
2.25
rish Cobbler. Second size. All good potatoes for planting. . . . . .

Single Sack Bu. 150 Lbs.

Early Ohio. The standard extra early potato. Light pink, nearly round with blunt ends. Disease-free seed............. 
Early Six Weeks. Like early Ohio in all respects. One of the very best ex-

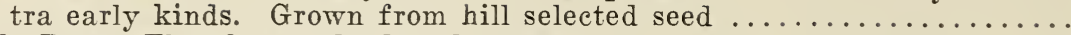

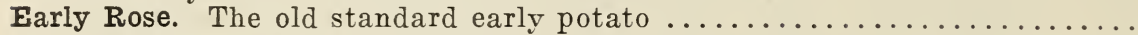

Spalding Rose. Large round potatoes of the Rose type. A heavy yielder but

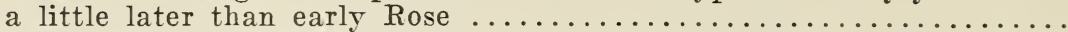

Green Mountain. A standard late potato of finest quality. Yields well in some localities, notably in New England. Crop inspected and all dis-

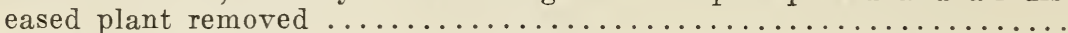

NUMBER 9. One of the heaviest yielding late potatoes we know of. Round, white, medium shallow eyes, vines very strong and free from disease.

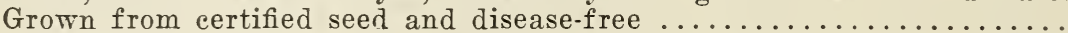

Heavy Weight. One of the heaviest yielding yet produced. Round to oblong, medium shallow eyes, purple sprouts, pure white skin. Very vigorous

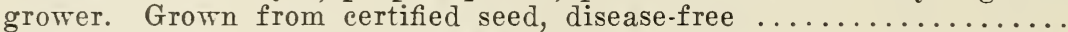

GOLDEN RURAI or RURAL RUSSET. One of the very best late potatoes, almost blight-proof, vines very strong and vigorous and produce immense yields of handsome, round, white potatoes. Disease-free seed

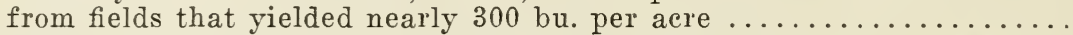

SPORT. A new variety that is practically blight-proof. See our general

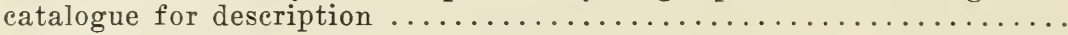

Single Sack

bu. $150 \mathrm{lbs}$

$2.25 \quad 5.00$

$2.00 \quad 4.50$

$2.00 \quad 4.50$

1.754 .00

$1.50 \quad 3.25$

$1.50 \quad 3.25$

$1.50 \quad 3.25$

$1.75 \quad 4.50$

Note-We can ship potatoes in wooden barrels holding $3 \mathrm{bu}$. (180 lbs.) if so ordered. The price of $\mathrm{a}$-barrel is three times the single bushel price. If the bushel price is $\$ 2.25 \mathrm{a}$ barrel would be $\$ 6.75$.

\section{PUMPKIN}

SMALI SUGAR or Pie Pumpkin. Small, round, deep yellow and of good quality. Early and prolific..........

WINTER LUXURY. A little larger than Small Sugar, netted skin, light yellow, and of very fine quality.

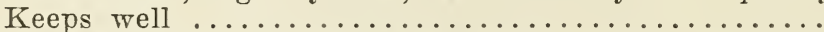

Mammoth Potiron, or King of Mammoths. Immense fruit, often weighing over $100 \mathrm{lbs}$. Color salmon pink, flesh deep yellow. Easily raised and a valuable pumpkin for

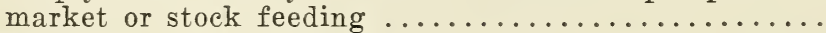

Large Cheese. Flattened, ribbed, mottled green and light yellow

Connecticut Field, or Big Tom. The common yellow field pumpkin

$\begin{array}{cccc}\text { Oz. } & & 1 / 4 \text { Lb. } & \text { Lb. } \\ \$ .08 & \$ .25 & \$ .75 \\ .10 & & .25 & .80 \\ & & & \\ .15 & & .35 & 1.20 \\ .08 & .20 & .60 \\ .08 & .20 & .55\end{array}$

\section{RADISH}

For forcing, Early Scarlet Globe and Harris' Special Scarlet Forcing are the most popular the former is oval in shape while the latter is round. Both grow very rapidy. Crimson Giant Globe is similar to Early Scarlet Globe, but grows larger and requires a little more time to mature.

For the open ground, Early Scarlet Globe is excellent. Earliest Scarlet White Tipped is very handsome and resembles French Breakfast, which is more oval in shape. Icicle is a fine long, white radish, smooth and of fine quality.

Philadelphia. White Box is round, grows rapidly and is excellent for forcing and open ground.

White Strasburg, Giant White Stuttgart and Delicacy are large, white radishes for summer and fall use. Winter radishes are sown in July or August and used in the fall and winter. Chinese Rose is the best red variety. Long Black Spanish is also of fine quality.

Earliest Scarlet Globe Short-leaf. Called also "Red

Oz. $\quad 1 / 4 \mathrm{Lb} . \quad \mathrm{Lb}$. Rocket," "20 Days" and "Startle." Oval shaped, of very rapid growth and good for foreing...........

EARLY SCARLET GLOBE. The most popular variety for foreing and outdoor culture. Oval to round in shape, very bright red, flesh white, firm and crisp. Our seed is very fine.

CRIMSON GIANT GLOBE. Very large forcing radish. Not so early as Early Scarlet Globe, but larger and stands

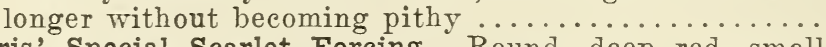

Harris' Special Scarlet Forcing. Round, deep red, small leaves and extremely early. Valuable for foreing

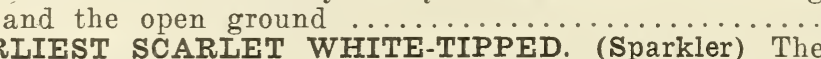

ARIIEST SCARIET WHITE-TIPPED. (Sparkler) The
radishes are round and are white on the bottom and part way up the sides. This is the finest strain of white-tipped radish

PHILADELPHIA WHITE BOX. A fine pure white, round, or ball-shaped radish for foreing or open ground. The radishes are handsome and of the best quality. 
DELICACY. A very fine white radish for summer or late

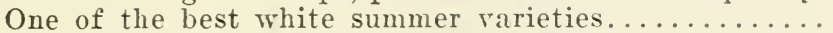

ICICLE. Long, slim, white radish of very rapid growth.

Lady Finger or White Vienna. Long, slender white radish of fine quality. Excellent for forcing and open ground.

Long Scarlet Short Top. Excellent long radish for open

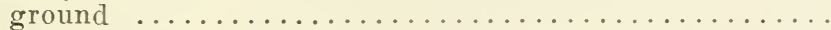

Chartier. Grows $t$ to 5 inches long. briglıt red with white

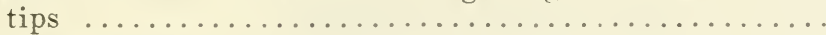

French Breakfast. Oval, witl white tips; early.........

White Strasburg. Large, long, white summer radisl].....

Giant White Stuttgart. TerY large, round or top shaped

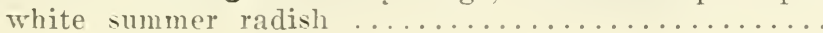
fall use. Of globe shape, pure white and of fine quality. The best long white radish for forcing in open ground.

\begin{tabular}{|c|c|c|c|}
\hline .10 & $\$$ & .2 .5 & $\$$ \\
\hline .10 & & .25 & \\
\hline .10 & & .25 & \\
\hline .10 & & .25 & \\
\hline .10 & & .25 & \\
\hline .10 & & .25 & \\
\hline .10 & & 25 & \\
\hline .10 & & 25 & \\
\hline
\end{tabular}

\section{Winter Varieties of Radish}

Sow in August and store in moist sand for winter market.

Chinese Rose. About 5 inches long, red skin, with white

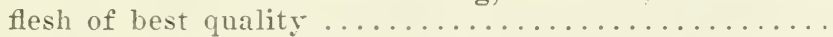

Long Black Spanish. Skin black, flesh white and very solid,

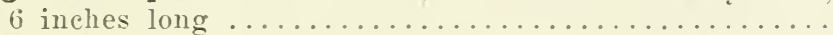

Black Spanish Turnip. Round or turnip-shaped roots.....

California Mammoth White. Tery large white radish;

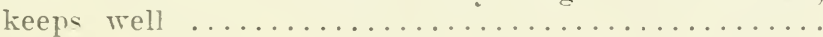

$\begin{array}{cccc}\$ .10 & \$ 25 & \$ & .85 \\ .10 & .25 & & .85 \\ .10 & .25 & & .85 \\ .10 & .25 & .85\end{array}$

\section{RHUBARB or PIE-PLANT}

Myatt's Linnaeus. Early, large red stalks.

$\begin{array}{ccc}\mathrm{Oz} . & 1+\mathrm{Ll} . & \mathrm{Lb} . \\ .12 & .30 & 1.10\end{array}$

\section{SQUASH-Summer Varieties}

The Giant Crookneck, usually sells best in market, although Mammoth White Buslı Scallop (called "Crmling", in the South) is in demand in many cities. The fruit is saucer" shaped and scalloped around the edge.

Italian Tegetable Marrow, called also "Cocozelle", (Italian-"Zucchetta nana de Milano"'), is now in much demand. The fruit is long, mottled, dark and light green, and grows on a bushy plant without runners. It is used when half grown.

Early Bush Crookneck. Most popular summer squash.

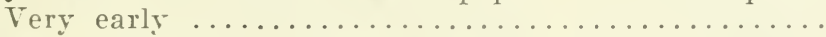

GIANT BUSH CROOKNECK. Larger than the old Bush

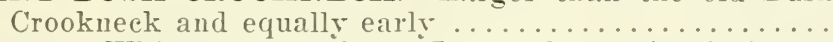
Mammoth White Bush Scallop. Large, flat, white fruit... Early Yellow Bush Scallop. Similar to the White, except in color

$\mathrm{Oz}$. ${ }^{1}+$ Lb.

Lb.

ITALIAN VEGETABLE MARROW. Long, mottled green

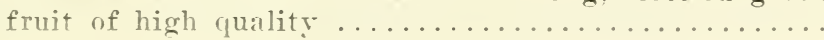

$\begin{array}{ccc}\$ 12 & \$ .40 & \$ 1.10 \\ .12 & .30 & 1.10 \\ .12 & .30 & 1.00 \\ .12 & .30 & 1.00 \\ .12 & .30 & 1.10\end{array}$

\section{SQUASH-Fall and Winter Varieties}

Boston Marrow and Prolific Marrow are the first to ripen and are excellent for market in the fall, but do not keey as well as the later varieties like Hubbard, Delicious and Qual ity, which can be kept all winter if put in a dry place where ther will not freeze.

The Improved IIarted Hubbard grows larger than the true Hubbard, and the shell is .overed with lumps or "warts"' making a squash that sells well in market, but we do not think the quality is quite as good as the true old Hubbard.

Delicious and Quality are both finer squashes than Hubbard, but do not yield quite as much and are profitable for market only where there is a demand for squash of high quality rather than size and appearance.

QUALITY. A new winter squash, small in size, but of very fine quality-better than any squash we know of.....

Boston Marrow. Popular fall squash, deep orange color..

Prolific or Orange Marrow. Tery similar to above, but of deeper orange color. A valuable squash for fall market

Essex Hybrid. Large, flattened at the ends, thick flesh of

U7.

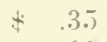

.015

05

.15
1/. Lb.

Lb. 


\title{
SQUASH-Continued
}

DELICIOUS. Smaller than Hubbard, but of finer quality

HUBBARD-True. Smooth, dark green fruit of high quality

$$
\begin{aligned}
& \$ \begin{array}{llll}
\text { Oz. } & 1 / 4 \text { Lb. } & \text { Lb. } \\
.12 . & \$ & .30 & \$ 1.25
\end{array} \\
& \begin{array}{lll}
.12 & .30 & 1.10
\end{array}
\end{aligned}
$$

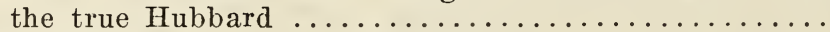

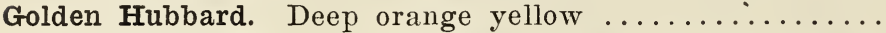

BLUE HUBBARD. A very large squash of the Hubbard shape but the color is blue-gray. The shell is very hard

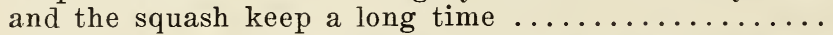

\section{SALSIFY or VEGETABLE OYSTER}

\author{
Mammoth Sandwich Island. The largest and best variety $\$ \begin{array}{llllll} & .15 & \$ & .40 & \$ 1.50\end{array}$
}

\section{SORREL}

Improved Broad-leaved

$\$ \quad .12 \$ .40$

$\$ 1.40$

\section{SPINACH}

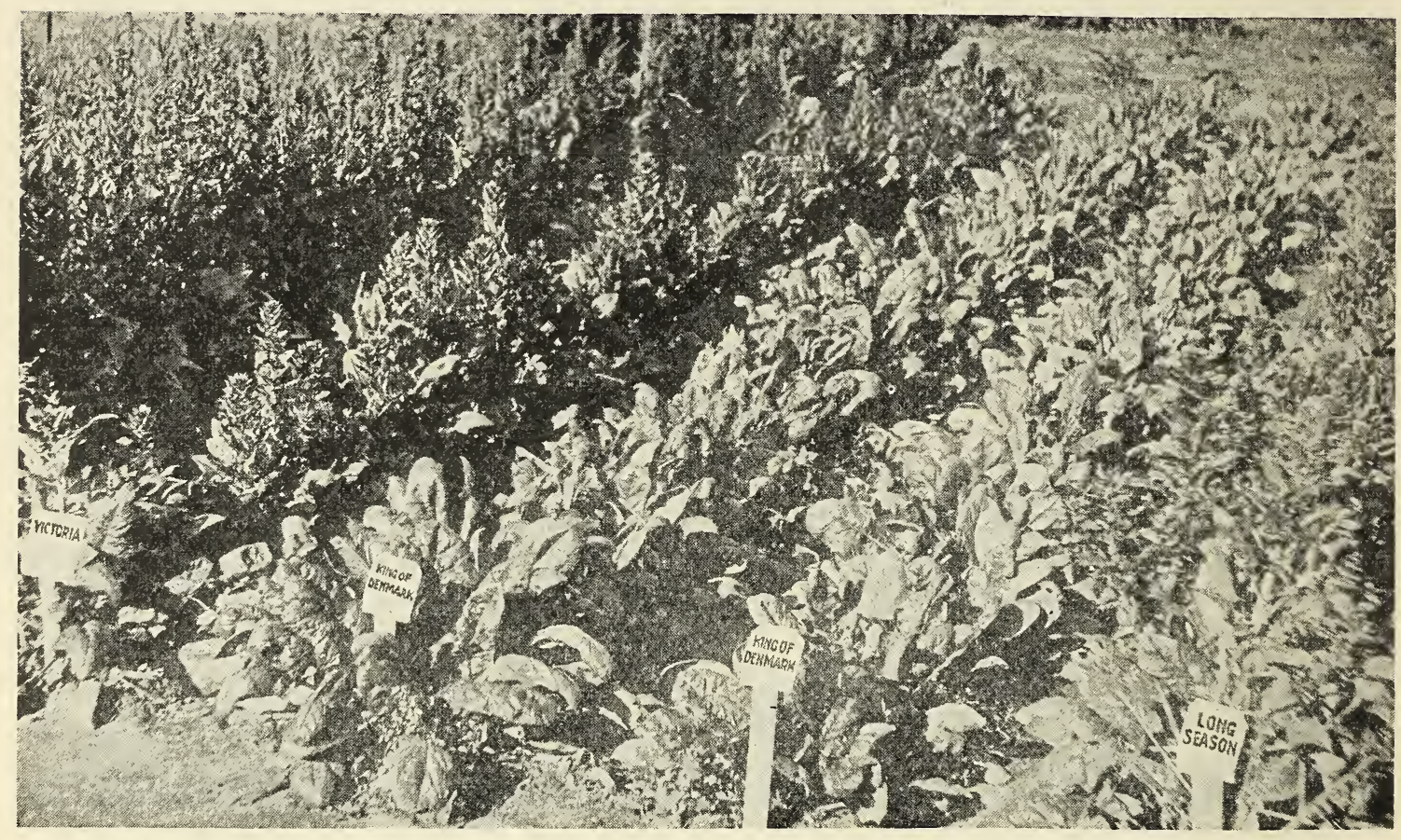

Photograph showing two rows of King of Denmark Spinach between Victoria and Long Seasons. Note that both the latter have run to seed while the King of Denmark is still in good condition and growing.

\section{KING OF DENIMARK SPINACH}

Those who have tried this new Spinach know it is a wonderful improvement over all other kinds. It not only grows fast and produces a large yield, but it stands two weeks longer before running to seed. The leaves are broad, heavy, dark green, and somewhat blistered like a Savoy cabbage. The remarkable thing about it is that it stands so long before putting up a seed stalk. This is a great advantage to the gardener, as he does not have to sell the whole crop within a few days as with the other kinds.

The King of Denmark spinach resembles Long Season, but grows much larger than that variety and stands ten days or two weeks longer.

A letter worth reading-from Prof. W. A. Orton, U. S. Department of Agriculture, Washington, D. C., June 17, 1920.

"I write to compliment you on the spinach, King of Denmark which you introduced this year. I find it of very exceptional merit as a long-standing spinach under our spring conditions. Planted March 25th on fairly fertile Norfolk sandy loam it was still in good condition on June 10th when the last was cut, with leaves covering nearly two feet of row, very tender and of superior quality. Two seedings of Savoy spinach on the other hand have come up and gone to seed during the interval.-W. A. Orton, Pathologist.",

Price of King of Denmark Spinach for 1923 . Oz. 10c; 1/4 1b. 20c; 1b. 60c; $101 \mathrm{bs}$. or more 55c per $1 \mathrm{~b}$. 


\section{SPINACH}

Norfolk or Bloomsdale Saroy-leaf has deep green blistered leares, but runs to seed rery quickly. Long Season has similar leaves and stands much longer. The new "King of Denmark", is similar to Long Season, but is larger, stands up better and remains without running to seed longer. Tiroflay is a rery rapid grower and has long, somewhat pointed leares not as thick as Eskimo, which does not grow quite so rapidly, but stands a longer time and is darker green. Victoria has round, very dark green leaves and stands well without rumning to seed. For wintering over, we recommend Eskimo, Norfolk Saroy-leaf and Long Season, all of which are hardy.

KING OF DENMARK. Stands longer in hot weather than any other kind. $10 \mathrm{lbs}$.

Lb.

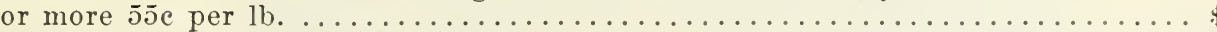

ESKIMO or GIANT THICK-LEAVED. An improved variety with very large, thick, dark green leaves; grows rapidly and stands well without rumining to seed. Hardy and an excellent kind for wintering over. $10 \mathrm{lbs}$. or more, $30 \mathrm{c}$ per $\mathrm{lb} . .$.

VICTORIA. Round, thick leaves, deep green and blistered. An excellent kind for

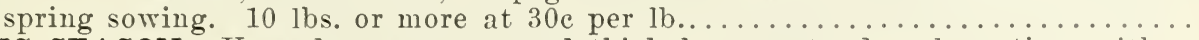

LONG SEASON. Very deep green, round thick leaves, stands a long time without running to seed. $10 \mathrm{lbs}$. or more, $35 \mathrm{e}$ per $\mathrm{lb}$.

Giant Crumpled Leaf. Terv large rounded leaves blistered or crumpled. Grows rapidly and rields more than most other kinds. A valuable variety. $10 \mathrm{lbs}$. or

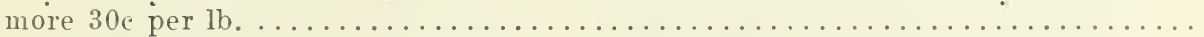

Norfolk Savoy-leaf. Round, blistered leaves, $10 \mathrm{lbs}$. or more, 28c per lb. .

VIROFLAY. Very large pointed leaves, rapid grower and comes on very early. 10 lbs. or more, $30 \mathrm{c}$ per $1 \mathrm{~b}$.

Long Standing. Round, deep green leaves. $10 \mathrm{lbs}$. or more, $30 \mathrm{c}$ per $1 \mathrm{~b} . . . . . . .$.

NEW ZEALAND. Not a true spinach. Valuable for summer. Oz., 10c; 1/4 1b. 25c

\section{TURNIPS}

Early Milan, both the Purple Top and White, grows rapidly and is the first to mature. The next is Purple Top Strap-leaf, which is very similar but a little later. Purple Top White Globe is a little later but a much better turnip and is the most popular variety for market. White Egg is a handsome white-egg shaped turnip, and Golden Ball a nice, smooth, round, rellow variety which grows rapidly. Snowball is round in shape like Golden Ball, but snow white. Yellow Stone is larger and more flat, while Yellow Aberdeen is globe-shaped and grows to a large size, but is hetter suited for feeding stock than for market.

EARLY WHITE MILAN. Very early, flat, white turnip..

EARLY PURPLE TOP MILAN. The earliest purple top turnip, very fine

PURPLE TOP WHITE GLOBE. Like Strap Leaf, but round instead of flat. Tery fine fall turnip............................

PURPLE TOP STRAP-LEAF. White, purple top, flat, very

rapid grower $\ldots \ldots \ldots \ldots \ldots \ldots \ldots \ldots \ldots \ldots \ldots \ldots \ldots \ldots$
Snowball.

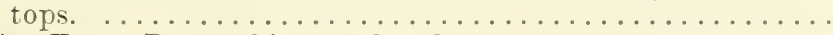

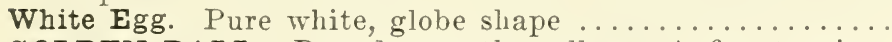

GOLDEN BALL. Round, smooth, yellow. A fine turnip..

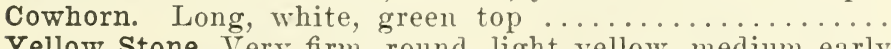

Yellow Stone. Very firm, round, light yellow, medium early

Yellow Aberdeen. Large, round yellow turnip; very firm and keeps a long time.

\begin{tabular}{|c|c|c|}
\hline $\begin{array}{l}\mathrm{Oz} . \\
.12\end{array}$ & $\begin{array}{c}1 / 4 \mathrm{Lb} . \\
\$ \\
.35\end{array}$ & $\begin{array}{r}\text { Lb. } \\
\$ 1.25\end{array}$ \\
\hline .12 & .30 & 1.00 \\
\hline .08 & .15 & 50 \\
\hline .08 & .15 & 50 \\
\hline .08 & .20 & .60 \\
\hline .08 & .20 & 60 \\
\hline .08 & .20 & 60 \\
\hline .08 & .15 & \\
\hline .08 & .20 & \\
\hline .08 & .20 & 0 \\
\hline
\end{tabular}

\section{RUTA BAGAS OR SWEDE TURNIPS}

Breadstone. Small, oral, white turnip for talle use.......
Macomber. A white purple top Swede of very fine quality for table use

PERFECTION SELECTED SWEDE. A fine selected strain of purple top yellow ruta baga. Grows large but is very smooth and of fine grain. The best yellow ruta baga for market

Imperial Purple Top. Large, yellow, smooth and a heavy yielder

White Sweet or French. A good White Swede turnip with green top 


\section{Harris' Thoroughbred Tomatoes}

We have for years made a special point of raising high quality tomato seed. We raise the seed on our own farm and practice the most careful breeding methods to improve the strains.

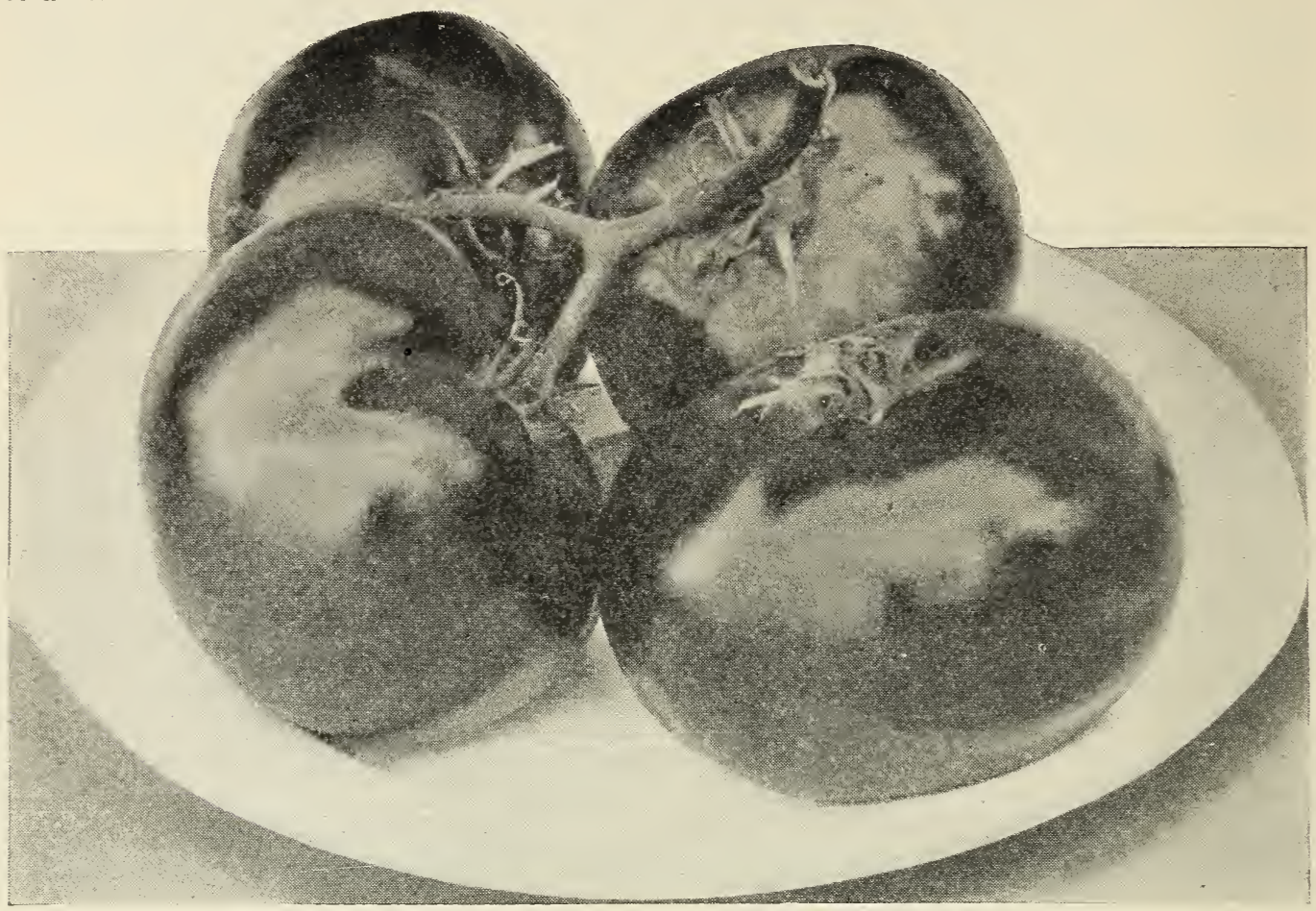

\section{Harris' Special EXTRA EARLY Strain of EARLIANA TOMATO}

We are quite sure that all our customers who have raised our special strain of Earliana tomato will agree with us that it is the earliest and smoothest and best colored stock of Earliana obtainable. This is a good deal to sav, but we have tried all the best strains of Earliana and cannot find one that is quite equal to our own stock either in earliness or quality. There are other tomatoes offered under different names which are said to be earlier than Earliana, but we have found none to be anv earlier and most of them are irregular in shape and not colored well.

This special strain of Earliana is not only extremely early (there is no tomato earlier), but the fruit is perfectly smooth, very solid and firm and is well colored right up to the stem. The vines are more vigorous and healthy than most strains of this variety.

Gardeners find this is a most profitable tomato to raise. The early crop brings high prices and the fruit that ripens later is of such good shape and color that it brings almost as much as the later varieties.

We offer seed of our own growing at Moreton Farm. It is Northern Grown as we are on the north border near Lake Ontario. Ounce 40c; 1/4 1b. $\$ 1.25 ; 1 b . \$ 4.50$.

"Your Earliana tomato in field test with Burpee's and Henderson's beat by 3 days, and three days last season meant a profit of 5 to $8 \mathrm{c}$ per lb." C. B. Carter, Columbus, Ohio.

Your seeds proved to be all you claim for them, but your Earlinana tomato is surely a winner (our receipts from one-half acre were \$375.00.' F. B. Battersbr, Vineland, N. J. Aug. 29, 1922.

"I wish rou could have seen our tomatoes while growing. There were no others in the surrounding cuntry near so fine. You must have been careful to have Your strains true to name. From Earliana and Bonny Best we had ripe tomatoes much in advance of others around us, and they were certainly fine. The Stone were splendid, but the frost took most of them. Large, smooth, perfect tomatoes, but many did not have time to ripen. In ordinary rears the Stone is all right." - W. T. Craig, Limestone, $\mathrm{Pa}$.

\section{JOHN BAER}

We have improved our stock of John Baer so that it is now even better than when first introduced. We know of no other kind quite equal to it for second early or main crop.

The fruit is large, smooth, deep red, and colors right up to the stem.

We regard this variety as the best medium early tomato for market or canning.

Seed of our own growing from very choice fruit. Oz. 40c; 1/4 1b. \$1.10; 1b. \$4.25.

"I have grown John Baer tomatoes ever since it was introduced and think more of it each ear and I want to say that the seed I got of you last year was the best I ever had. I sold over 1,000 worth from 2.200 staked plants, and tomatoes were plentiful and very cheap in this section of the country" $W$ O. Kindig. Medina, Ohio. Narch 3, 1922 


\section{BONNY BEST TOMATO}

This tomato is much like the John Baer. Our selected strain has rery smooth, handsome, bright red fruit of good size and well colored.

The fruit does not often erack and we did not see a single one affected with black rot in a large field we had growing at Moreton Farm.

One good point about this tomato which is not possessed by the John Baer is that the stem comes off the fruit when picked, so does not injure other tomatoes when they are packed together.

We are sure there is no finer strain of Bonny Best tomato than the seed we are offering this seasoll. It was saved from very carefully bred plants and practically every fruit was of perfect color and shape. Oz. $40 c ; 1 / 4$ lb. $\$ 1.10 ; 1 b . \$ 4.25$.

\section{TOMATOES}

The very earliest tomatoes are never quite as large and well colored as the later varieties, lout Earliana of a carefully selected strain is the nearest perfect of any really early variety we know of. Harris Extra Early Earliana is earlier than the old strain, and also colors better. John Baer is about a week later than Earliana, ripening with Bonny Best and has slightly larger fruit than that excellent variety. Chalk's .Jewel is a little later and larger. Success is still later and is similar to Stone, but ripens earlier than that variety.

Of the pink varieties, Jume Pink is the earliest and resembles Earliana, except in color. Early Detroit is a little later, but has large, smooth, well-colored fruit. New Globe is a few days later and the fruit is as round as an apple. Ponderosa is very large, but irregular and does not color well around the stem and is not suitable for market. Trucker's Farorite is large, smooth and matures medium late.

Extra Early Earliana (Harris‘ Special Strain.) See opposite page

$+.40$

JOHN BAER. Large. smooth fruit, colors perfertly even bright red all over. Does not erack, very prolific. One

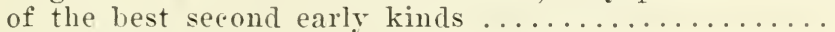

BONNY BEST. Tery earlỵ, large, smooth and bright red

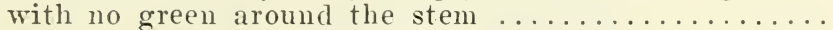

June Pink. Tery similar to Earlina except as to color,

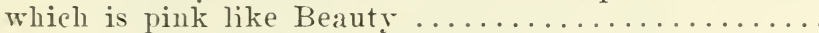

EARLY DETROIT. A pink variety with smooth, evenly colored fruit of good size. A very fine pink tomato..

CHALK'S EARLY JEWEL. Medium early, smooth and

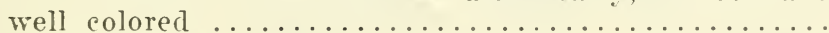

SUCCESS. Tery fine main crop variety. Smooth, well colored and solid. Seed of our own growing; rery

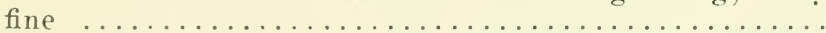

STONE. We have a very fine strain of this grand tomato. There is nothing finer than a first-class strain of Stone, but it ripens rather late for the most northern parts of the country. Seed of our own growing at Moreton Farm

NEW DWARF STONE. Plants like Dwarf Champion with fruit like Stone, very prolific and a valuable variety

TRUCKER'S FAVORITE. Large, smooth, pink, medium late

Imperial. One of the best pink tomatoes for main crop.

GLOBE. (Livingston's) Is round as an apple; color deep pink. One of the very best varieties of this color ....

PONDEROSA. Magnificient, heary, solid fruit, often weighing 2 llss. or more; light pink; medium early; does not color very well

Dwarf Champion. Early, pink, medium size, dwarf plant Livingston Beauty. Large, late, pink, very smooth

Red Cherry. Tery small red fruit in elusters.

Yellow Plum. Plum shaped, small, vellow fruit

Red Plum. Small plum shaped fruit

Red Pear or Fig. Small pear-shaped red fruit.

GOLDEN QUEEN. Large, smooth vellow fruit

Ground Cherry or Husk Tomato. Yellow fruit in liusles.

Superb Salad. Small, rery smooth red fruit suitable for serving whole in salads. Tery prolific.

White Beauty. A pure white tomato of fine quality, smooth and handsome

WEST'S PEERLESS FORCING. i valuable variet for growing in greenhouses. Of mediun size, colored well and bears well under glass.........

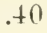

Li). $+4.50$

1 Ll.

$\begin{array}{rr}1.25 & 4.75 \\ .80 & 3.00 \\ .90 & 3.50 \\ 1.10 & \ldots . \\ 1.25 & 3.50 \\ 1.00 & 4.50 \\ 1.10 & \ldots . \\ 1.00 & \ldots \\ 0.5 & \end{array}$

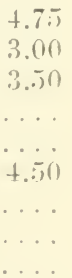

\subsection{0}


Basil. Used for flavoring soups and sauces. Plant about 18

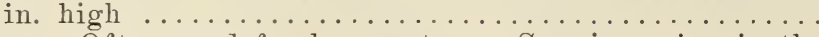

Borage. Often used for bee pasture. Sow in spring in the

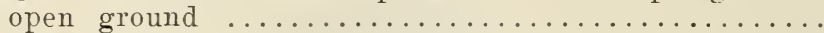

Caraway. Hardy biennial seeding the second year after sow.

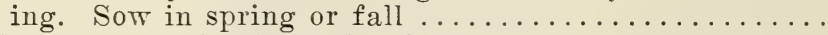

Coriander. Sow in the spring in the open ground........

DILL. Used for flaroring cucumber pickles, etc .........

SWEET MARJORAM. Easily grown from seed sown in the

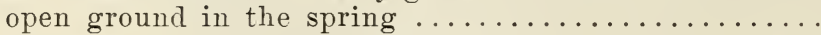

Fennel (Sweet.) The leares are used for flavoring. Easily

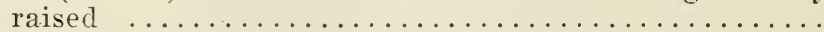

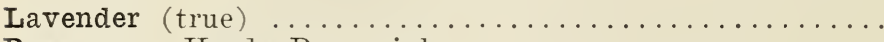

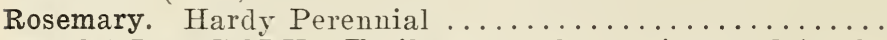

SUMMER SAVORY. Easily grown by sowing seed in the open ground in the spring. Plant grows about a foot high with small, narrow leares, which are dried on the

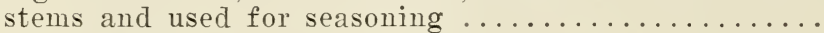

SAGE, Broad-leaved. When once started will last for years. Should be in every garden. Sow in the open ground

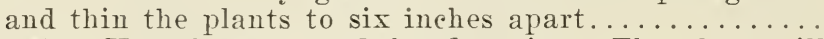

THYME. Tery largely used for flavoring. The plant will survive the winter if given a little protection........

Wormwood. A medical herb used largely for planting in poultry yards for chickens to feed on .............

Oz.

\section{VEGETABLES, PLANTS, ROOTS, ETC.}

All plants will be ready for delivery when they can be dug in the spring, unless otherwise stated. We usually cannot dig plants before the 10 th of April.

\section{ASPARAGUS ROOTS.}

Giant Argentueil. 1-year roots, strong and heary

WASHINGTON. New rust-resistant strain bred up br the U. S. Department of Agriculture. We offer very strong 1-year-old plants

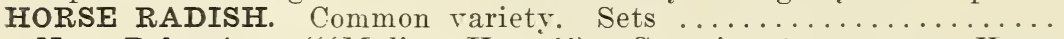
100 1000

New Bohemian. ("Maliner-Kren.") Superior to common Horse

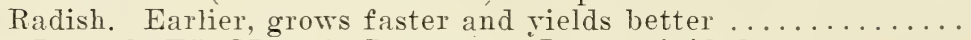

RHUBARB ROOTS, Myatt's Linnaeus. Large divided roots........

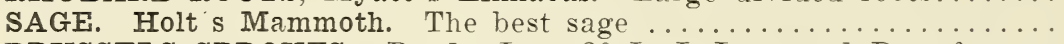
BRUSSELS SPROUTS. Ready June 20 L. I. Improved Dwarf...... CABBAGE PLANTS. Early transplanted plants, ready April 15-Mar 15. Well hardened in cold frames and will stand considerable frost. Early Jersey Wakefield, Copenhagen Market, Enkhuizen Glory.... Field grown plants, ready middle of June. All leading rarieties CAULIFLOWER. Early transplanted plants ready May 1. Snowball Field grown plants ready June 20. Snowball and Danish Giant

CELERY. Early transplanted plants ready May 15. Golden SelfBlanching and White Plume Field grown plants, readr last of June. Varieties: Golden SelfBlanching, White Plume, French's Success, Giant Pascal, Easy Blanching

PEPPERS. Strong transplanted plants, ready last of May. Ruby King, Harris' Earliest, Giant Crimson, Neapolitan, Giant Cayenne......

PEPPERS. Untransplanted Plants. Ready April 10 to. May 1st. Same varieties named abore. Weight packed for mailing $100^{\circ} 1$ llb.; 1000 $41 \mathrm{lbs}$.

TOMATOES. Ready May 10 to June 15 . Strong transplanted, wellhardened plants. Extra Early Earliana, John Baer, Bonny Best, Success, Stone. Drarf Champion, Early Detroit (pink), Ponderosa (pink)

TOMATOES Untransplanted Plants. These are taken direct from the seed bed and should be set in frames and allowed to grow for two weeks or more before setting in the field. They are strong, stocky seedlings 3 to $t$ in. high. Ready April 10 to May 15th. Same varieties as named above. Weight packed for mailing $1001 \mathrm{lb}$. $10005 \mathrm{lbs}$. 


\section{HARRIS' FLOWER \\ SEEDS}

Fully appreciating the fact that the floral grower is dependent upon the quality of the seed he sows, we are continually putting forth our best efforts to acquire the very best strains and types. Many of these varieties are grown on Moreton Farm where our customers are always welcome to eome and inspect our stocks.

The following list is not complete, but it contains those varieties most generally used by floriculturists. For a complete list and descriptions see our general catalog which will be mailed you about Feb. 1st.

Please order by number, as it will help us in filling your order.

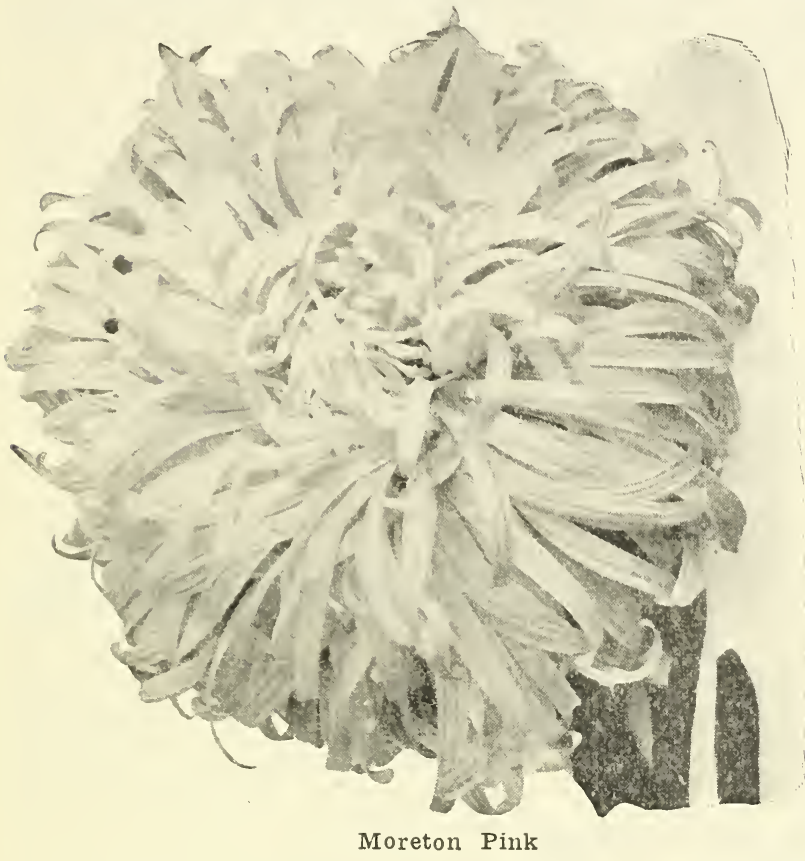

\section{ASTERS}

Every year the increasing demand for Moreton grown Aster seed forces us to steadily increase our acreage of Asters and each succeeding year our Asters are mounting to a higher standard of quality.

All of our seed is either grown on Moreton Farm or very carefully grown especially for us by an expert Aster grower.

Our fleld of Heart of France, Rochester Lavender, Peerless Pink, Moreton Pink and Ostrich Feather Asters were exceptionally fine this year, and we are offering the best Aster seed that we have ever had.

\section{Queen of the Market}

The standard earliest Aster to bloon and on this account often the most profitable to raise for market. It is the most profuse blooming sort and full, double. medium sized flowers are borne on long clean stems. The plants should be started rery early in the hot-bed or greenhouse and set in the field just as early as the ground can be worked, because this variety set out later will not produce long stem..

w1201-White

w1202-Blush pink

w1203-Rose

$\begin{array}{ccc}\text { Tr. pkt. } 1 / 40 z & 0 z . \\ .15 & .30 & 1.00\end{array}$

w 1201 - Lavender

w1205-Purple

w1200-Mixed colors

\section{Crego Asters}

This is the larce fluff $r$ flower that is so nuch admired. The fluffy mass of long twisted petals combined with the rich colorings make an aristocratic flower that is the admiration of every one. We hare a splendid strain of this type, the plants leing especially robust growing. The steins are long and stiff and hold the flower's ui) off the oromind. W 1101 -WHITE

W1402-SHELI PINK

W1403-ROSE

W1104-LAVENDER

W1 105 -PURPLE

W 1406-IAVENDER PINK

W1400-MIXED COLORS

$\begin{array}{lll}.15 & .30 & 1.00 \\ .15 & .30 & 1.00 \\ .15 & .30 & 1.00 \\ .15 & .30 & 1.00 \\ .15 & .30 & 1.00 \\ .1 .5 & .30 & 1.00 \\ .10 & .20 & .15\end{array}$

\section{American Beauty Asters}

The Latest Blooming Aster

This is a new variety from California and is certainly very handsome. The plants are of the branching type, unusually visorous and produce a profusion of very large full flowers on long strong stems. The flowers have incurved petals making them almost rlobed shaped. This will prove a very fine aster for cut flowers for nearby market or shipping. W1802-SEPTEMBER BEAUTY. Shell Pink 


\section{AGERATUM}

W2011-BLUE PERFECTION. One of the most satisfactory hedeling plants being covered witl hloom from early summer until frost. Raised easily from secd sown out of doors or started earlier in a hothed or greenhonse. One ounce will sow solo to 1,00() feet of row. 1/4 oz, $25 \mathrm{c}$; oz. $75 \mathrm{c}$.

\section{ALYSSUM}

A very pretty little plant, eovered with pure white flowers. Which are produced all flurough the smmer. Especially usetul for edering and borders. One ounce will sow soll feet.

W2021-LITTLE GEM. The dwart viniety for low edgings

W2020-SWEET (MARITIMUM). Sweet scented and taller growing

\section{ASPARA GUS}

T'le teparagus is always in strong demand with every florict. w2090-PIUMOSUS NANUS. Open-air Seed. The fine leaved variety used with cut-flwers. per 100 seeds; $\$ 2.25$ per 1,000 seeds.

W2091-SPRENGERI. The popular variety for growing in hanging haskets. boxes. ete. 15c per 100 seeds: $\$ 1.00$ per 1,000 seeds.

\section{BEGONIA}

W2130-SEMPERFLORENS, Prima Domna Tr. pkt. $30 \mathrm{c} ; 1 / 16$ oz. \$2.00.

\section{BELLIS Perennis or Double English Daisy}

For edging to beds and borders in cool shady places. They bloom very early. The Monstrosa viriety does not bloom quite as freely as the other, but the flowers are much larger.

W2140-DOUBLE MIXED. The best quality obtainable of the ordinary fr. pkt. 1/40z. 0z.

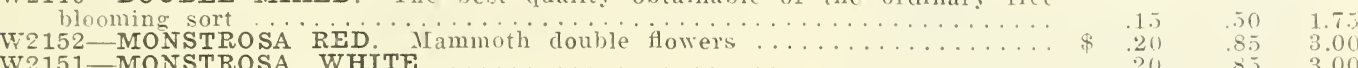

W2151-MONSTROSA WHITE

W2150-MONSTROSA MIXED COLORS

\section{CALENDULA}

Calendula are raised for both cut flowers and for the spring bedding plant trade. The orange and the yellow are rery desirable autumn colors and will continue to give a wealth of bloom after most other outdoor flowers are gone.

We hare, this rear, two splendid new Calendulas of our own growing that are far superior to the ordinary strains. They are of larger size, more full double, deeper color, and large rigorous plants. One ounce will sow 300 feet of row

W2201-ORANGE KING, Harris' Special Deel' orange. Oz. $50 \mathrm{c} ; 1 / 4$ lb. $\$ 1.75$.

w2202-IEMON QUEEN. Harris' Special Bright yeilow. Oz. 50c; $1 / 4$ 1b. $\$ 1.75$.

W2203-PRINCE OF ORANGE. Oz. 20c; 1/1 1b. $60 \mathrm{c}$.

W2204-SULPHUR YELLOW. Oz. 20c; 1/4 lb. $60 \mathrm{c}$

\section{GYPSOPHILA}

W2991-ANNUAL BABY'S BREATH. Elegans Alba Grandiflora. I fine flowered form that is splendicl to srow for the cut-flower mar. ket. The fine sprays of dainty white tower ar. Hows in clemand with the florists. One ounce will sow 350 feet of row. Sow nt 14 day intervals. Oz. 15c; 1/4 lb. $40 \mathrm{c} ; 1 \mathrm{~b}$. $\$ 1.20$.

\section{CYCLAMEN}

W2490-PERSICUM. One of the choirest of all the green-house or window plants, producing large bulbs in one year from seed. $t$ choice mixture of best colors and the most satisfactory variety to raise from seerl Tr. pkt. (about 100 seeds) $50 \mathrm{c}$.

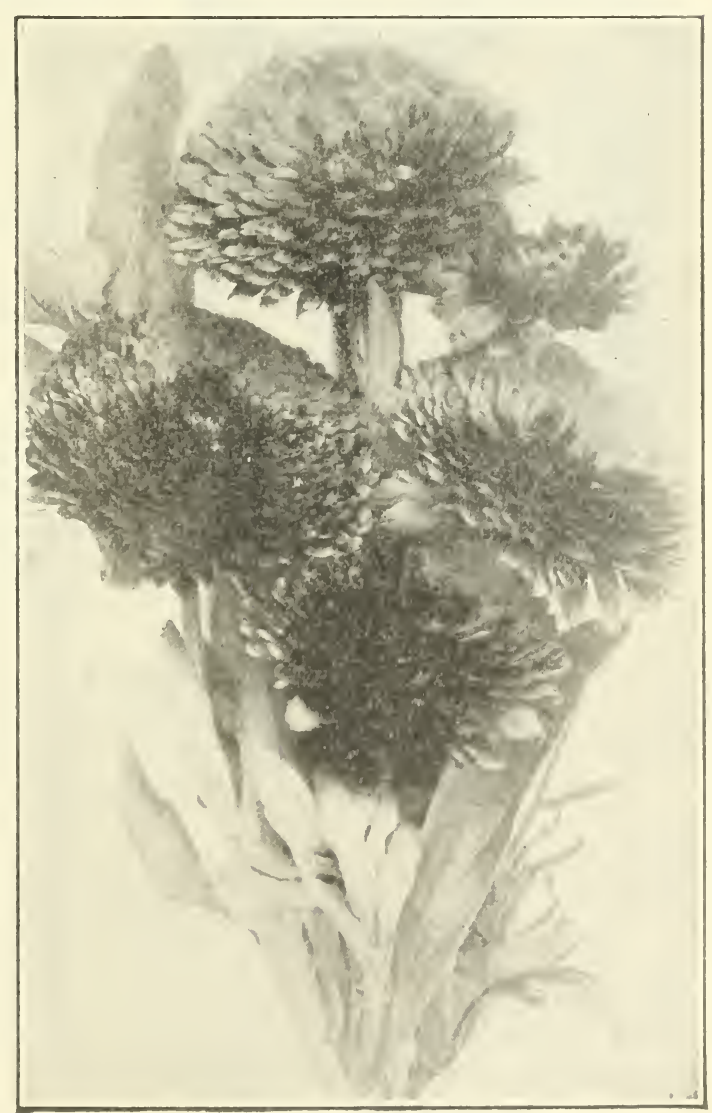

Calendula, Orange King 


\section{CARDINAL CLIMBER}

W2315-A very popular annual climber which sell well as potted plants. Tr. pkt. 25c; oz. \$2.00.

\section{CARNATION}

W23C0-GIANT MARGUERITE, Mixed Colors. This is the most desirable sort for outdoor blooming. Seed sowed inside late in winter will produce an abundance of large flowers all summer. There is a large demand every spring for plants of this variety. $1 / 4 \mathrm{oz} .25 \mathrm{c} ; \mathrm{oz} .85 \mathrm{c}$.

\section{CASTOR OIL BEAN}

W2500-ZANZIBARENSIS. These make a very good proposition when grown inside in pots until about 6 inches high and then sold with the spring bedding plants to be used for lawn decorations or screens. They are also very effective when the seed is sown out-doors. One ounce should produce 20 plants. Oz. $15 \mathrm{c} ; 1 / 41 \mathrm{~b} .50 \mathrm{c}$.

\section{CANDYTUFT}

Candytuft is so easily grown and so universally used by florists that no floral grower should neglect to make successive sowings all summer, while the last sowing in the autumn will produce early spring flowers. One ounce will sow 400 feet.

W2275-GIANT HYACINTH-FLOWERED. An improved Empress with immense spikes oz. $1 / 4 \mathrm{lb}$. of large flowers

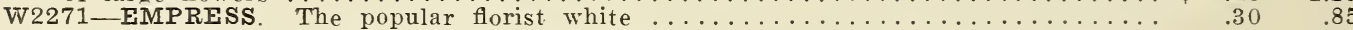

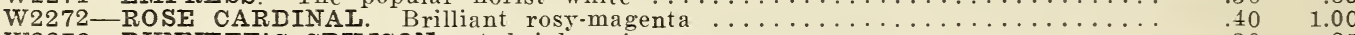

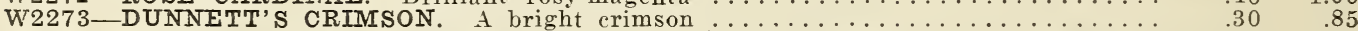
W2270-MIXED COLORS

\section{CENTAUREA}

CYANUS Double or Bachelor's Buttons. The new double Cornflowers or Bachelor's Buttons are proving very profitable as cut-flowers. We have a superior strain that is quite double and clear colors. One ounce will sow 150 feet of row.

w2321-WHITE. Without the blue eye.... $\begin{array}{cc}1 / 4 \\ .20 & 0 z .75\end{array}$ W2322-ROSE. Pink shades ............ $.20 \quad .65$ W2325-BLUE. A favorite color $1 / 4 \mathrm{lb} . \$ 1.50 \quad .15 \quad .50$ W2320-MIXED COLORS.......1/4 lb. $1.00 \quad .15 \quad .35$

AMERICANA or Basket Flower (Harris' Special). The largest of the Centaurea. Grows 4 feet high with large delicately formed flowers 4 inches across. Our own growing. W2331-WHITE ............... \$ .15 .50 W2334-LAVENDER. A beautiful color ... $.15 \quad .50$ W2350-GYMNOCARPA or Dusty Miller. This is the finely cut, white-leaved "Dusty Miller'" so much used for edging and in porch boxes and vases. Seed sown in January or February will make nice large plants for early spring. $1 / 4$ oz. $30 \mathrm{c} ;$ oz. $85 \mathrm{c}$.

\section{COBEA SCANDENS}

W2572-A good blue-flowered vine to grow for the spring bedding plant trade. One ounce of seed should produce 300 good plants. 1/4 oz. $15 \mathrm{c}$; oz. $35 \mathrm{c}$.

\section{COLEUS}

W2510-EXTRA CHOICE IARGE-LEAVED MIXTURE. Richly colored foliage plants for groups on lawns, ribboning and pot culture Universally used in porch boxes and conservatory. Easily raised from seed the first season. Our mixture is the best we can obtain. Tr. pkt. 50c.

Double Blue Cornflower (Centaurea Cyanus)

\section{CELOSIA or Cockscomb}

The brilliant colored Cockscomb are becoming more popular for bedding plants and they are a. good thing to raise for a plant trade as well as for cut-flowers.

CHINESE WOOLFLOWER. This grows like the Plumed Cockscomb but the heads are more round and fluffy. The most attractive of the Cockscomb.

W2362-PINK

W2363-CRIMSON

Tr. pkt. $1 / 4$ oz.

THOMPSON'S MAGNIFICA (Celosia Plumosa). Tall growing with pyramidal heads of a bright feathery appearance.

W2373-CRIMSON

W2374-YELLOW

W2370-MIXED COLORS

Tr. pkt. oz.

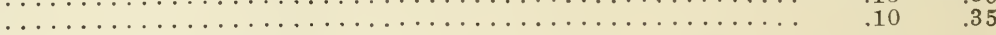

CRISTATA or TRUE COCKSCOMB. The old fashioned low growing cockseomb with the heavy crinkled heads resembling a rooster's comb. 


\section{COSMOS}

EARLY FLOWERING GIANT. (Harris' Special). Te have a large Early Flowering Cosmos of our own growing that is especially fine for our northern climate. We liave been growing this for a number of years constantly selecting for true early types with large broad-petalled flowers of good colors. Sown in the open ground in late spring this makes a splendid cut-flower. One omnce will sow 300 feet of row.

W2 $451-$ WHITE

W2453-RED

W2 450 - MIXED COLORS. A well balanced mixture . . . . . . . . . . . . ${ }^{1}+$ lb. $\$ .90 \quad .10 \quad .30$

$1 / 4$ oz. oz

15

DOUBLE CRESTED. A new and distinct type having large flowers with double centers. Of the same season as the late Cosmos.

W2 480 - MIXED COLORS

Tr. pkt. $1 / 4$ oz.

W2 270 -MAMMONTH LATE FLOWERING. Mixed Colors. The largest of the Cosmos but very late flowering and must be forced early to get bloom in our northern climate. $1 / 4$ oz. 10c; oz, 30c.

\section{DIDISCUS (Blue Lace Flower)}

W2746-COERULEUS. One of the new popular cut flowers. Lavender-blue lace-like flowers on good stems and a profuse bloomer. Tr. pkt. 25c; oz. $\$ 1.50$.

\section{DRACAENA}

W2750-INDIVISA. The popular center plant for vases, porch boxes, etc. The long, narrow, graceful foliage adds just the right effect. As the seed is sent out in the berry it should be rubbed out before planting. Tr: pkt. $10 \mathrm{c} ;$ oz. $30 \mathrm{c} ; 1 / 4 \mathrm{lb} . \$ 1.00$.

\section{EVERLASTINGS}

These flowers are easily raised and there is often a great demand for them. They are annuals and flower early when seed is sown in the open ground.

HELICHRYSUM or Straw Flowers. The flowers are 2 inches across and are on stems 2 feet long. The most popular "'Everlasting.'

W3071-SILVER BALL. White

Tr. pkt. oz.

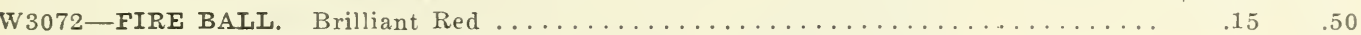

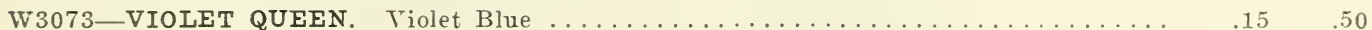

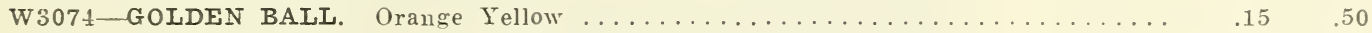

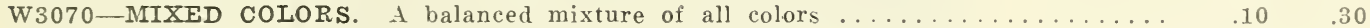

w2000-ACROCLINIUM, DOUBLE. Mixed Colors. Small double red, white and pink flowers on stems a foot or more in length. $1 / 4$ oz. $15 \mathrm{c} ;$ oz. $40 \mathrm{c}$.

W8C80-XERANTHEMUM. Small, semi-double flowers with silvery foliage. Plants grow 2 feet high. $1 / 4$ oz. $20 \mathrm{c}$; oz. $50 \mathrm{c}$.

W4200-RHODANTHE (SWAN RIVER EVERLASTING). Nixed colors. A charming annual "'everlasting' about 1 foot high. $1 / 4$ oz. $15 \mathrm{c}$; oz. $40 \mathrm{c}$.

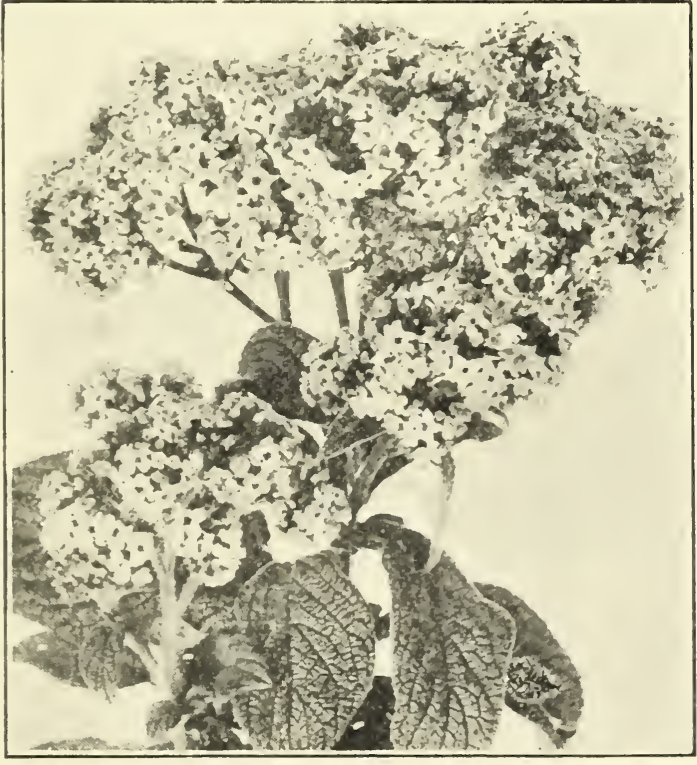

Large Flowering Heliotrope

\section{HELIOTROPE}

W3130-LEMOINE'S GIANT. Plants grow 2 feet high and produce very large clusters of blue flowers of delicious fragrance. The seed should be started in the greenhouse. One trade packet should produce at least 500 plants. Tr. pkt. 20c; $1 / 4$ oz. $50 \mathrm{c} ;$ oz. $\$ 1.75$.

\section{ANNUAL LARKSPUR}

The Tall Double Stock-flowered Larkspur are most excellent to raise as an outdoor cut-flower, blooming profusely all through the summer. This is one of the specialties we grow on Moreton Farm.

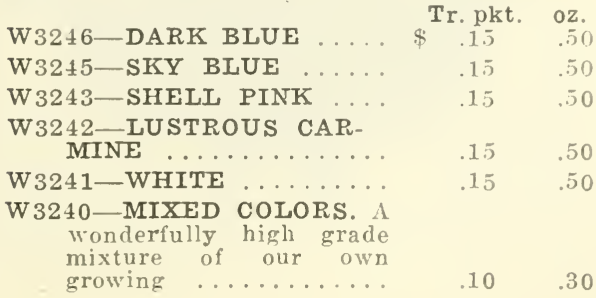




\section{LOBELIA}

This class of plants is one of the prettiest that can be grown for hanging baskets, porch boxes or edging to the flower bed, and there is always a good sale for the plants. They grow but a few inches ligh and the dainty, finely cut foliage is dotted throughout the season with an abundance of small blue Howers.

w3300-CRYSTAI PAIACE Compacta. (True). The finest dalk blue for bedding. Tr. pkt. $20 \mathrm{c} ; 1 / 4 \mathrm{oz}$,

$60 \approx ; 0 z . \$ 2.00$.

W3292-SAFPHIRE (Trailing). For hanging baskets and porch boxes. Tr. pkt. 15c;1/4 oz. $30 \mathrm{c} ; 0 \mathrm{z}$. $\$ 1.00$.

\section{MARIGOLDS}

Marigolds are a good proposition for the floral grower to raise for either cut-flowers or plants. For cut-flowers, the African varieties are the best. For low borders and edging; use the French Marigolds.

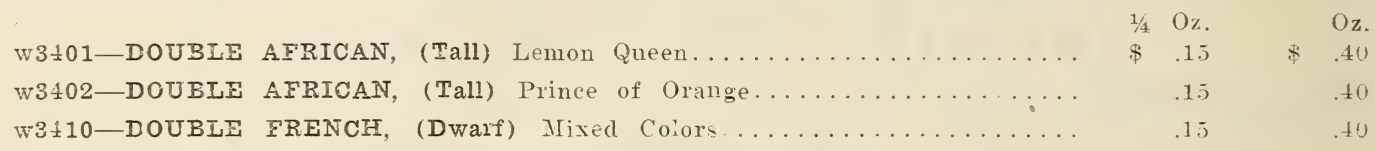

\section{MIGNONETTE}

L'sed for cut-flowers, making flower beds and sometimes forced in the greenhouse. W3434-GOLIATH (Red) Large spikes of a decided red coicr..........\$.20 \$ .60 W3432-BISMARI (New) The largest grower and remaining green a long time.. $\quad .25 \quad .75$

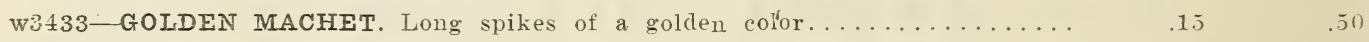

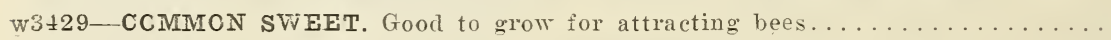

\section{NASTURTIUM}

W3501-TAII. IOBB'S IMPROVED. Mixed Colors. The best of the climbing varieties. Large flowers and a good mixture of colors w3500-TALL. Mized Colors. A good mixture of climbing sorts..... W3600-DWARF. Mixed Colors. Low growing plants, both light and

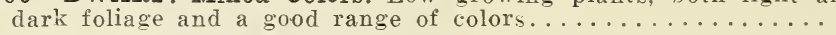

\begin{tabular}{|c|c|c|c|}
\hline $\begin{array}{l}O z \\
.10\end{array}$ & $\$$ & $\begin{array}{l}1 / 4 \\
.30\end{array}$ & $\&$ \\
\hline .10 & & .20 & \\
\hline .10 & & .25 & \\
\hline
\end{tabular}

For descriptions of named rarieties see our General Catalog.

We will be glad to quote you special prices on larger quantities.

\section{PANSY}

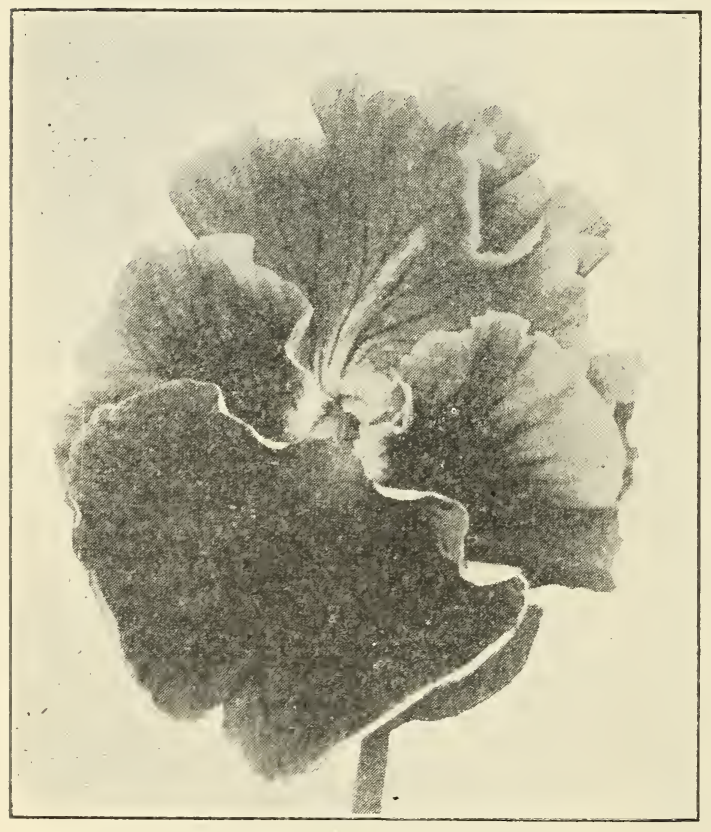

Pansy-Masterpiece
Each year we are improring the quality of our Pansy seed as we realize the importance of highest quality Seed to the Pansy plant grower and we feel sure that we are offering the highest grade Pansy seed for the lowest possible price.

w3700-HARRIS' SPECIAL MIXTURE. This is our own mixture that is especially made up of some of the very best varieties and choicest colors. The make a special point of this mixture as a medium priced mixture for the florists' plant trade. The flowers are all large many of them ruffled and with bright colors predominating. Tr. pkt. $20 \mathrm{c} ; 1 / 4$ oz. $\$ 1.00$; oz. $\$ 3.00$.

W3704- “HARRIS' BEST"' PANSY MIXTURE As the name implies, these are our BEST Pansies. The flowers are extremely large with the deep velrety colors. A large percentage hare fluted or ruffled petals. Our price for this quality of Pansies is very low. Tr. pkt. $25 \mathrm{c} ; 1 / 4$ oz. $\$ 1.40 ;$ oz. $\$ 5.00$.

W3702-MASTERPIECE MIXTURE or GIANT RUFFLED. The flowers of this mixture have fluted or ruffled petals, which adds much to the beauty of the wonderfully rich colors. This stock mar be depended upon to be well ruffled. Tr. pkt. $25 \mathrm{c} ; 1 / 4$ oz. $\$ 1.35 ;$ oz. $\$ 1.75$.

w3701-GIANT TRIMARDEAU. Mixed Colors. We make this high grade mixture by mixing together proportionate quantities of choicest colors of the large-flowering Trimardeau Pansies. This assures you of a mixture well balanced as to color and of large flowers. A really good mixture at a low price. Tr. pkt. $15 \mathrm{c} ; 1 / 4$ oz. $65 \mathrm{c} ;$ oz. $\$ 2.00$. 
W3730-FAIRY QUEEN. Dainty blue with white edge

w3731-SNOWFLAKE. (Trimardeau) Clear white of large size

w3732-GOLDEN YELLOW (Trimardeau). Larse clear vellow

w3733-ROYAL BLUE. (Trimardeau) Large hlue shade

W3710-MIXED COLORS. I good bright mixture of the common sorts

w5760-VIOLA OR TUFTED PANSIES. small thowers but very profuse

bloomers during the hot summer month. Extensively used for

summer bedding in sung position. where they annot he watered,

irixed coins:

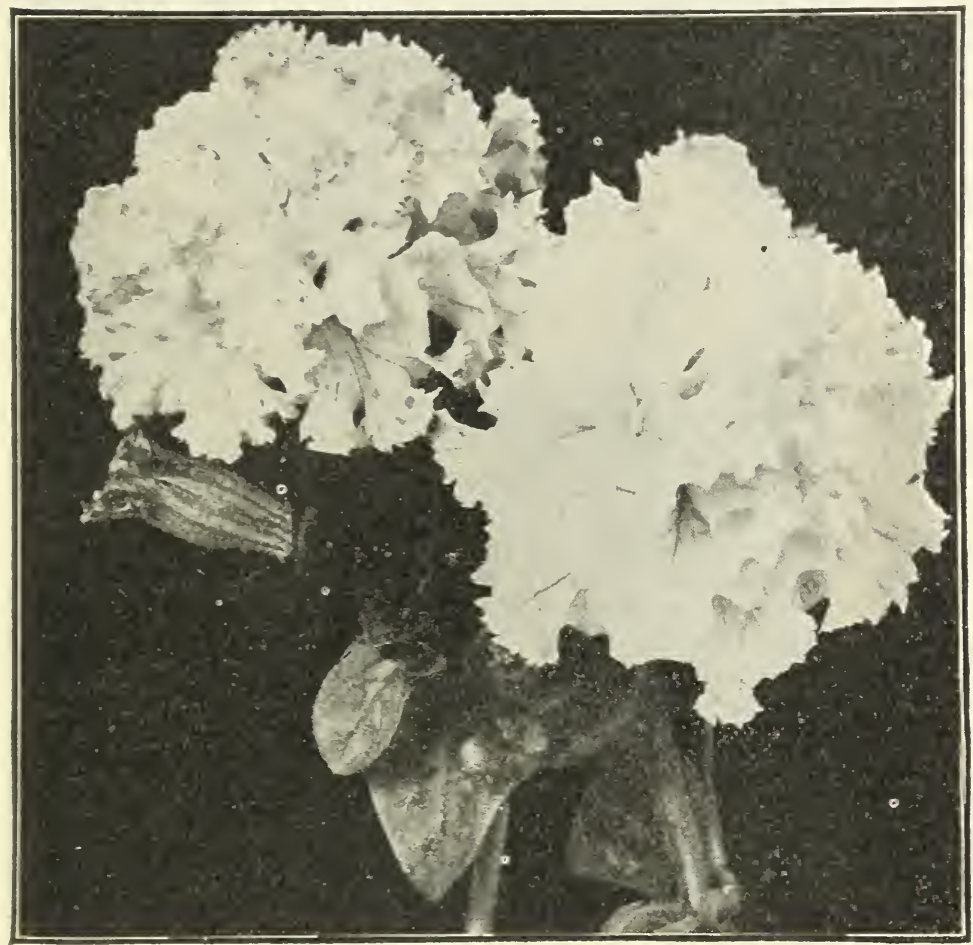

Harris' Perfection Double Petunias-(Photograph 1/2 natural size)

$\begin{array}{rrr}\$ .25 & .70 & \$ 2.00 \\ .25 & .70 & 2.00 \\ .25 & .70 & 2.00 \\ .25 & .70 & 2.00 \\ \ldots & .25 & .85\end{array}$

$\therefore 0 \quad .50 \quad 1.75$

\section{PETUNIAS}

One of the most popular bedding plants to raise, especially the large double and single ruffed. They are easily grown from seed sown in February or March and always command a good price.

w38 C - HARRIS' PERFECTION DOUBIE. Our strain of Double $\mathrm{Pe}$ tunias is exceptionally fine, coming $85 \%$ to $95 \%$ true double and the bal. ance semi-double. The flowers are very large and in a splendid range of colors. This seed is grown especially for us by a Petunia expert and is the very best Double Petunia seed: 200 seeds $75 \mathrm{c} ; 500$ seeds $\$ 1.40$; 1000 seeds $\$ 2.25$.

w3815-RUFFLED T R I UMPH. (See illustration of the cover of our Retail Catalog). This splendid Petunia of recent introduction we consider not only the best pink petunia, but also the best self-colored single petunia. The color is a very bright shade of deep saimon-pink while the flowers though not excep. tionally large are of the superbissima type and thoroughly- ruffled. It produces true to type from the seed and is really a rery satisfactory rariety to raice. 200 seeds $30 \mathrm{c} ; 500$ seeds $65 \mathrm{c} ; 1000$ seeds $\$ 1.00$.

w3801-RUFFLED GIANTS OR GIANTS OF CALIFORNIA. Very large, single fiowers with beautiful ruffled edges in many shades of color. 200 seeds $25 \mathrm{c} ; 500$ seeds $50 \mathrm{c} ; 1000$ seeds $85 \mathrm{c}$.

w3803-FRINGED HYBRIDS. These are leautiful single petunias for bedding. The tlowers are not in large as the Rufled Giants, but are unch larger then common petunias and the edges of the petals are beautifully fringed. 500 seeds $20 \mathrm{c} ; 1000$ seeds $35 \mathrm{c} ; 1-16 \mathrm{oz}$. $\$ 1.50$.

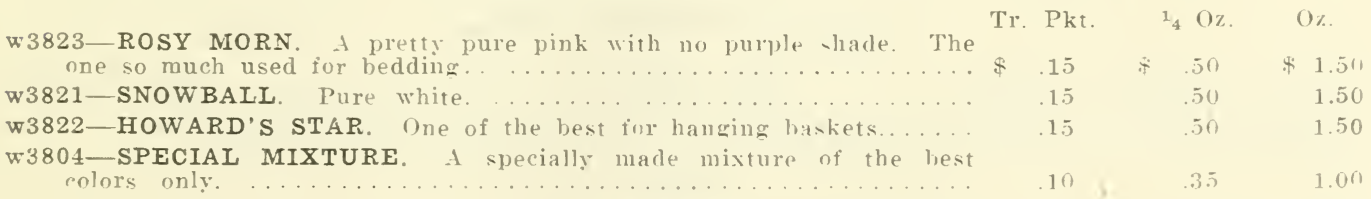

\section{SALVIA}

There is no other bedding plant so much in demand as salvia. and a good even stand of Salvia is always appreciated by the customer. Our own srain of New England Grown Bonfire Salvia has all the qualities necessary to pleass your customers.

Tr. Pkt. $\quad 1 / 4 \mathrm{O} \%$

Oz.

w600-BONFIRE. This is our own sperial -train grov $n$ in New Eng-

land for a number of years and thoroughly acclimater to this latitude.

It grows evenly as to height, and is the earliest to blonm, every plant

coming into bloom at the same time.

W 4601 - SPLENDENS. Later blooming and taller growing than Bonfire.

W4602-DWARF ZURICH. Low growing and an eary and profuse 


\section{SWEET PEAS}

\section{New Early Flowering Varieties}

The New Early Flowering Long Season Varieties are the best for forcing under glass or for early flowering outside. The flowers are of the Spencer type, but commence to bloom about 15 days earlier.

PRICE. Any of the following Early Flowering Varieties: 0z. 55c; $1 / 4$

lb. $\$ 1.75$; lb. $\$ 6.50$ (except where noted).

\section{White}

W7001-SNOWFIAKE. A fine prolific white

w7016-SNOWSTORM. The largest pure white.

\section{Pink Shades}

w7006-SONGBIRD. Bluish Pink. w7005-HERCULES. Large rose-pink. W7009-MELODY. Resembles Coun: tess Spencer.

w7013-YARRAWA. The standard rose-pink of most markets.

\section{Blue}

W7018-BLUE BIRD. A good grow ing light blue self.

W7017-MRS. HARDING (New). A new shade of deep silvery-blue. Of immense size and much waved. PRICE per Trade Pkt. 50c; oz. $\$ 2.50$.

\section{Red Shades}

w7010-GLITTERS. A magnificent bright orange-scarlet that surpasses anything else in this color, and is much more sun-proof. PRICE per Trade packet $30 \mathrm{c} ; \mathrm{oz}$. $\$ 1.00 ; 1 / 41 \mathrm{~b} . \$ 3.00$.

w7012-FIRE KING. A scorching fire-red.

w7007-IIBERTY. Bright sun-proof crimson.

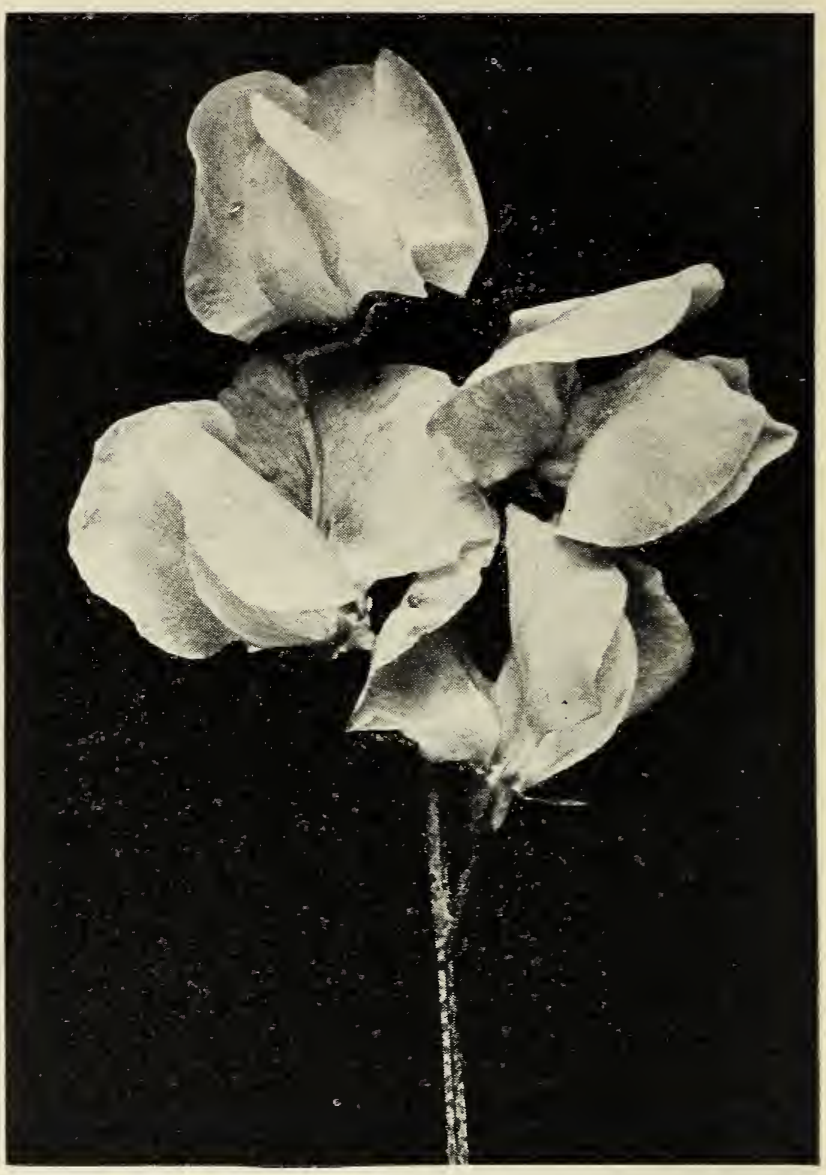

Early Melody

\section{Lavender}

w7011-I.AVENDER KING. A rich deep, true lavender

w7019-NIGHTINGALE. Like Florence Nightingale: a mauve-lavender of exceptional vigor and very prolific.

\section{Mixed Colors}

w7000-This is our own special mixture made up of some of all the above varieties (except two) and well balanced as to color. PRICE oz. $45 \mathrm{c} ; 1 / 4$ lb. $\$ 1.35 ; 1 \mathrm{~b} . \$ 5.00$.

\section{Spencer Sweet Peas}

The following varieties are the large waved or orchid-flowered Sweet Peas that have been the standard of beauty for the last few years. They come into bloom a little later than the Early Flowering varieties and are splendid to sow in connection with them. PRICE of any of the following Spencer varieties, (except where noted) oz. $25 \mathrm{c} ; 1 / 4 \mathrm{lb}$. $80 \mathrm{c} ; 1 \mathrm{~b}$. $\$ 2.90$.

\section{White}

w7501-CONSTANCE HINTON. A vigorous growing white. w7514-KING WHITE. A mammoth white of perfect form.

W7516-FIORADAIE FAIRY (New). A pretty creamy white of large size.

\section{Pink Shades}

w7502-HERCULES. Soft rose-pink of vigorous growth. W7504-MARGARET ATLEE. Beautiful deep creamy pink w7507-MRS. CUTHBERTSON. Giant flowered rose and light pink w7508-NEW MIRIAM BEAVER. Soft shell pink suffused with salmon.

\section{Red Shades}

W7510-TANGERINE (New). A new bright orange self of delicate tone. PRICE. Oz. 50c; 1/4 lb. \$1.75. W7517-THE PRESIDENT (New). Brilliant orange-scarlet of largest size.

W7509-DOBBIE'S SUNPROOF CRIMSON. II ganificent rich crimson scarlet. 


\section{SWEET PEAS-Continued}

\section{Lavender}

W7503-MARGARET MADISON. Clear azure blue of large size.

W7506-WEDGEWOOD. Mammoth silvery blue and a vigorous grower.

W7515-HAWLMARK LAVENDER (New). The purest lavender; A lavender containing no mauve tints. PRICE Trade pkt. 25c; oz. \$1.50.

\section{Purple}

w7513-ROYAL PURPLE. A strong growing rich royal purple.

\section{MIXED COLORS}

w7500-Our mixture is made by taking the right proportions of each of the above colors (except 4) and mixing the seed ourselves. In this way rou can be assured of a high grade mixture. PRICE. oz. $20 \mathrm{c} ; 1 / 4$ lb. $75 \mathrm{c} ; 1 \mathrm{~b} . \$ 2.50$.

\section{GRANDIFLORA SWEET PEAS}

w7700-MIXED COLORS. For those who want a good mixture at a cheap price we offer this mixture of good Grandiflora varieties. The colors are just as handsome as the more expensive sorts, but the flowers are smaller. Oz. $10 \mathrm{c} ; 1 / 4 \mathrm{lb} .25 \mathrm{c} ; 1 \mathrm{~b} .70 \mathrm{c}$.

\section{SCABIOSA (Annual)}

The annual Scabiosa are very good to raise for the cut-flower market. They have good, long stems the flowers of good size and in a splendid variety of desirable colors. They bloom in season for a fall market and are not injured by the first frosts.

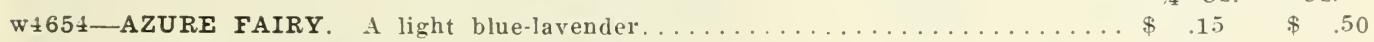

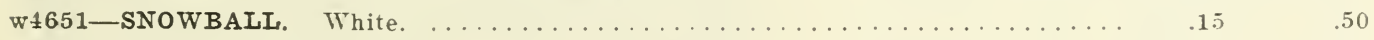

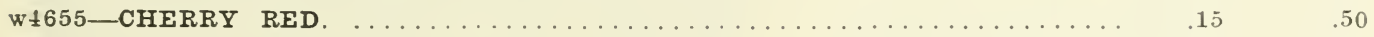

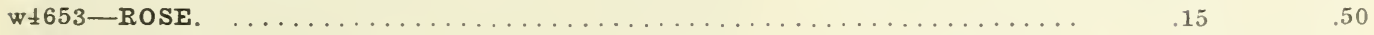

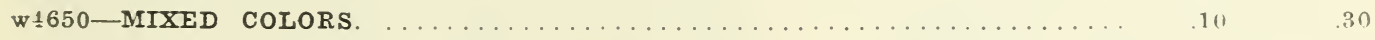

\section{SNAPDRAGONS}

Snapdragons are continually gaining in popularity both as a cut-flower and as bedding plants. Every spring we have a rery large sale for plants of the Tall rarieties. Our Snapdragon seed is of the best quality we can procure. To the florists' we list only the Tall Large Flowering varieties.

W5031-QUEEN VICTORIA. Pure white

w5032-VENUS. Light Pink. Similiar to Silver Pink

w5034-FIREFLY. Scarlet with yellow throat.

w5035-GOLDEN KING. Large clear yellow

W5037-NELROSE.

W5036-CRESICA.

w5030-MIXED COLORS. A well balanced mixture made up of all the

abore colors.

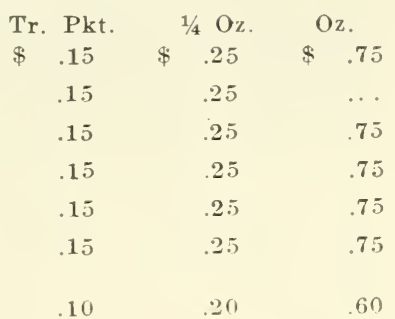

\section{STOCKS}

\section{Double Mammoth Flowering Plants}

We have given our Stocks very careful consideration and find that this strain is the most satisfactory for outdoor blooming. The branching plants grow about 2 feet high and are covered with long sprays of sweet-scented, double flowers.

w6001-MONT BLANC. Pure white. Tr. Pkt. $\quad 1 / 4 \mathrm{Oz} . \quad \mathrm{Oz}$. W6002 - BEAUTY OF NICE Flesh w6003-OLD ROSE. Attractire rose-pink.

$\begin{array}{lll}.25 & .75 & 2.50 \\ .30 & .80 & 3.00 \\ .25 & .75 & 2.50 \\ .25 & .75 & 2.50 \\ .20 & .60 & 2.00\end{array}$




\section{MAMMOTH VERBENIAS}

For porch boxes, lawn rases, or bedding, there is no plant better than Verbena. They are eas! to raise and can be sold at a price that will attract your customers. Our Terbenas are the Mammoth Flowering variety and are the largest and best we can possibly obtain.

w8001-WHITE. $1 / 4 \quad \mathrm{Oz} . \quad \mathrm{Oz}$

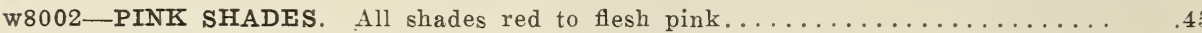

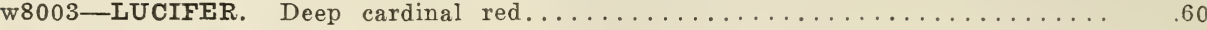

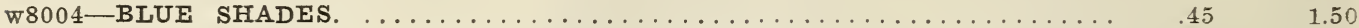

W8000-MIXED COLORS. A splendid mixture of all colors . . . . . . . . . . $\quad .35 \quad 1.00$

W8020-GIANT HYBRIDS, MIXED COLORS. A new strain of especiali iarge

flowers.

\section{ZINNIA}

\section{HARRIS' DOUBLE GIANT}

The raising of Zinnia seed is one of Moreton Farm specialties and we have worked up a strain of Double Giant Zinnias which we claim is the very best. They measure 5 to 6 inches across and are uniformly double. This year we are able to offer only two colors, and you can depend on them being almost 100 per cent. true to color. Each rear we find it necessary to raise a larger acerage of Zinnias to supply the increasing demand for Harris' Double Gian Zinnias.

w8104-SCARLET. A deep brilliant scarlet of mammoth size and velvety appearance. Tr. pkt. $10 \mathrm{c} ; 1 / 4 \mathrm{oz}$. $35 \mathrm{c} ; 0 z . \$ 1.25$.

w8105-YELLOW. A bright, clear, light golden-yellow. Tr. pkt. 10c; $1 / 4$ oz. $55 \mathrm{c}$; oz. $\$ 2.00$.

w8100-MIXED COLORS. Contains a wonderful variety of colors and flowers of largest size. Tr. pkt. $10 \mathrm{c} ; 1 / 4$ oz. $45 \mathrm{c} ;$ oz. $\$ 1.50$.

\section{LARGE FLOWERING DOUBLE ZINNIAS}

This is a strain of California grown seed that is grown for us by a very reliable and careful grower of high grade Zinnia seed, and we assure you they are splendid Zinnias, of large size, true to color, and good double. They are far better than ordinary stock.

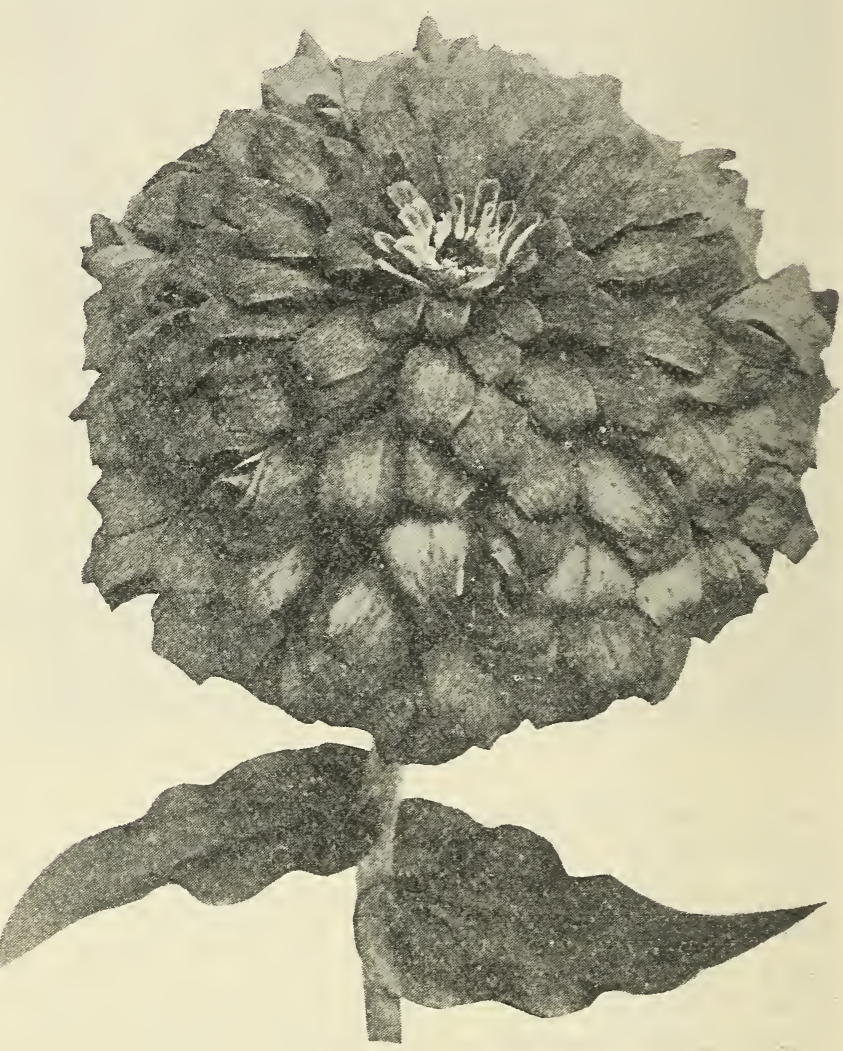

Harris' Double Giant Zinnia.

W8204-SCARLET.

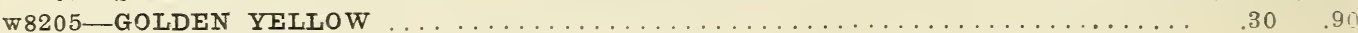

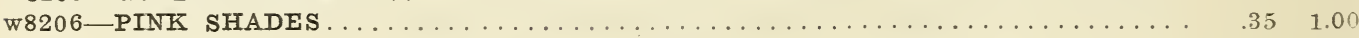

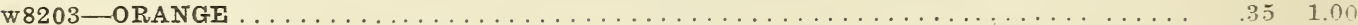

W8200-MIXED COLORS. Our own mixture made up of the above colors and many others not listed here

\section{MONTBRETIA BULBS}

\section{For Cut Flowers}

There is no Better Cut Flower Proposition on the Market To-day.

They are the best of the summer flower bulbs for the floral grower, giving a profusion of flower from mid-summer to late fall. They are new to the cut-flower market and as the bulbs can not be imported, the flowers are sure to command a good price for some time. Handle the bulbs in the same way as Gladioli. Te have a large stock of splendid bulbs of our own growing that we are offering at $\$ 6.50$ per $100 ; \$ 55.00$ per 1,000 . 


\section{SEEDS OF HARDY PERENNIALS}

We are large growers of the choicest raricties of hardy perennial plants and seeds and, with rery few exceptions, all of the seed offered is of our own growing and all is good fresh seed of the highest germination. The seeds of most peremnials do not retain their vitality for very long while many varieties, even at their best, germinate poorly or very slowly, so, for that reason it is best to sow only the freshest and best seed. As we are making a specialty of Hardy Perennial seeds you may feel sure that our seed is the best.

Description of these varieties will be found in our retail catalog as these are the same strains of seeds. If you are interested in Perennial Plants we will be pleased to quote you special priees on such varieties as we have on hand.

w2008-AGROSTEMIMA Coronaria. Bright crim-

son border plant. Tr. pkt. 10c; oz. $30 \mathrm{c}$. w2025-ALYSSUM Saxatile Compactum (Basket

of gold.) A fine early yellow for edging. T'r. pkt. $15 \mathrm{c} ;$ oz. $50 \mathrm{c}$.

w2040-ANCHUSA Italica, Dropmore Variety. A rapid growing blue for the shrubbery border. Oz. $25 \mathrm{c}$.

w2045-ANTHEMIS Kelwayi. A good yellow for cutting. Tr. pkt. $15 \mathrm{c} ; \mathrm{oz} .50 \mathrm{c}$.

AQUILEGIA. The raising of fine Aquilegia is one of our specialities and we believe we have the finest strain of Long. Spurred Aquilegia on the market.

w2070-Mrs. Scott Elliott's Long Spurred Strain, Mixed Colors. This is a strain we

hare been selecting for a number of years and has only the choicest colors and longest spurs. A large rield permits us to sell at this low price. Tr. pkt. 20c; oz. $\$ 1.50$.

w2071-Chysantha. A large growing clear yellow. Tr. pkt. 25c; oz. \$2.00.

w2072-Coruelea. Long spurred blue and white Tr. pkt. $25 \mathrm{c} ;$ oz. $\$ 2.00$.

w2073-Canadensis. Scarlet and Yellow. Tr. pkt. $20 \mathrm{c} ; 0 \mathrm{z}$. $\$ 1.50$.

w2080-ARABIS Alpina. (Rock Cress). I low growing white. Tr. pkt. $15 \mathrm{c} ; 0 \mathrm{z}$. $50 \mathrm{c}$.

W2081-ARMENIA Formosa (Sea Pink). Mixed Colors. A low growing cut-flower. Tr. pkt. $20 \mathrm{c} ;$ oz. $\$ 1.00$

w2178-BOLTONIA Latisquama.

Tall pink for late cutting or

border

Tr. pkt.

$\mathrm{O} \%$

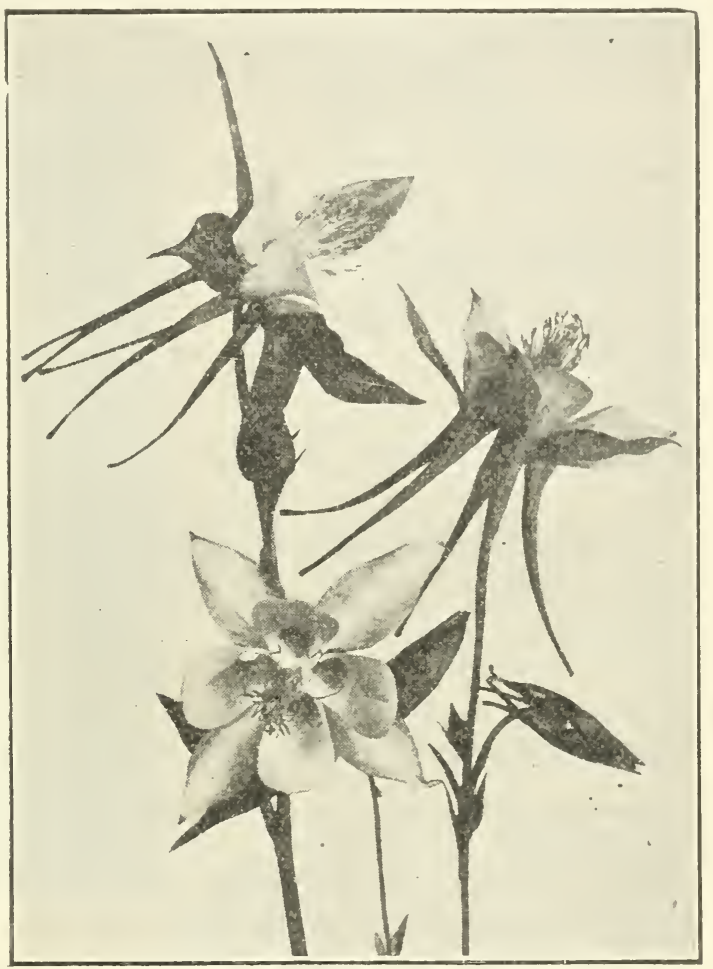

Mrs. Scott Elliot's Long Spurred Aquilegia

CAMPANULA (Canterbury Bells). There is always a big demand for plants of the rarious varieties of Canterbury Bells.

w2220-Single Mixed Colors (Camp Medium)

w2230-Cup and Saucer, Mixed Colors (C. Med. Calycanthema)

Tr. pkt. oz

w22 10 -Double Mixed Colors (C. Medium)

w2140-COREOPSIS Lanceolata. Tall golden yellow. A file cut flower.

w2720-DIGITALS Gloxiniodies (Foxglove). Mixed Colors

w2765-ECHINOPS Ritro. A thistle-like perennial much used as an everlasting

w2995-GYPHOFHILA Paniculata (Perennial Baby's Breath) very pretty small pure

white single flower

w3143-HEUCHERA Sanguinea (Coral Bells) Low growing red

w3251-LATHRYUS Latifolius (Perennial Sweet Peas) White

w3252-LATHRYUS Latifolius (Perennial Sweet Peas) Pink

w3273-IAVENDULA Vera Sweet-Scented Lavender

w3261-LINUM Perenne (Hardy Blue Flax)

W3334-LYCHNIS Chalcedonica (Jerusalem Cross) Scarlet

MALLOW MARVELS, Dreer's New Giant Hibiscus. Used for its rapid large growth, especially

in naturalizing.

w3361-White.

w3364-Red.

w3362-Pink.

w3365-Crimson Eye.

w3360-Mixed Colors. 


\section{DELPHINIUM (Hardy Larkspur)}

Whether grown for cut flowers or for plants to sell, there is no perennial of so popular demand. For some years we have been giving special attention to the producing of the right kind of Delphinium seed and we are now able to offer three strains of our own growing that we believe can not be surpassed.

w2640-MORETON HYBRIDS. This is a wonderfully fine strain of tall, vigorous growing plants with exceptionally heavy spikes of large double and single flowers. The colors range from single dark blue with white center to double light blue and shell pink. This is an especially high grade article. Tr. pkt. $30 \mathrm{c} ; 1 / 4$ oz. $65 \mathrm{c} ;$ oz. $\$ 1.85$.

w2645-BELIA DONNA. This is the beautiful light blue so much desired as a cut-flower. The flowers, which are dis. tributed so gracefully along the stems, are a very pretty shade of clear turquoise blue. Tr. pkt. 25c; 1/4 0z. 50c; 0z. $\$ 1.65$.

CHINENSIS. A distinct variety of spreading habit and fine feathery foliage and producing graceful sprays. Will bloom the first year from seed sown outdoors in the early spring. $1 / 4 \mathrm{Oz}$. Oz.

W2651-WHITE. $\$ \quad .20$ $\$ \quad .50$

w2652-BLUE. .20

HOLLYHOCKS, Chater's Superb Double. A magnificent strain of double Hollyhocks of our own growing.

W3102-NEWPORT PINK $\ldots \ldots \ldots \ldots \ldots \ldots . . . . .75$

w3104-RED.

.25

W3105-YELLOW.

.25

W3100-MIXED COIORS.

LUPINUS Polyphyllus. The hardy Lupins make splendid plants for the perennial border and the cut-flowers always sell well.

w3321-White. $\$ \quad .25$

w3323-Blue.

w3322-Rose.

w3320-Mixed Colors.

MYOSOTIS (Forget-Me-Not). No gardener should be without plenty of Forget-Me-Not plants always on hand.

w3493-ALPESTIS, ROYAL BLUE. Rich clear blue of tall growth $\$ .25$

$\$ \quad .75$

w3490-ALPESTRIS, MIXED COLORS. Pink and blue..

w3495-PAIUSTRIS SEMPERFLORENS. The true, old-fashioned "Forget-Me

Not," continuing to bloom from spring until autumn.

w3783-PENTSTEMON Barbatus Torreyii.

$\$ 20$

w3894-PLATYCODON Grandiflora (Japanese Ballon Flower.) Blue..........

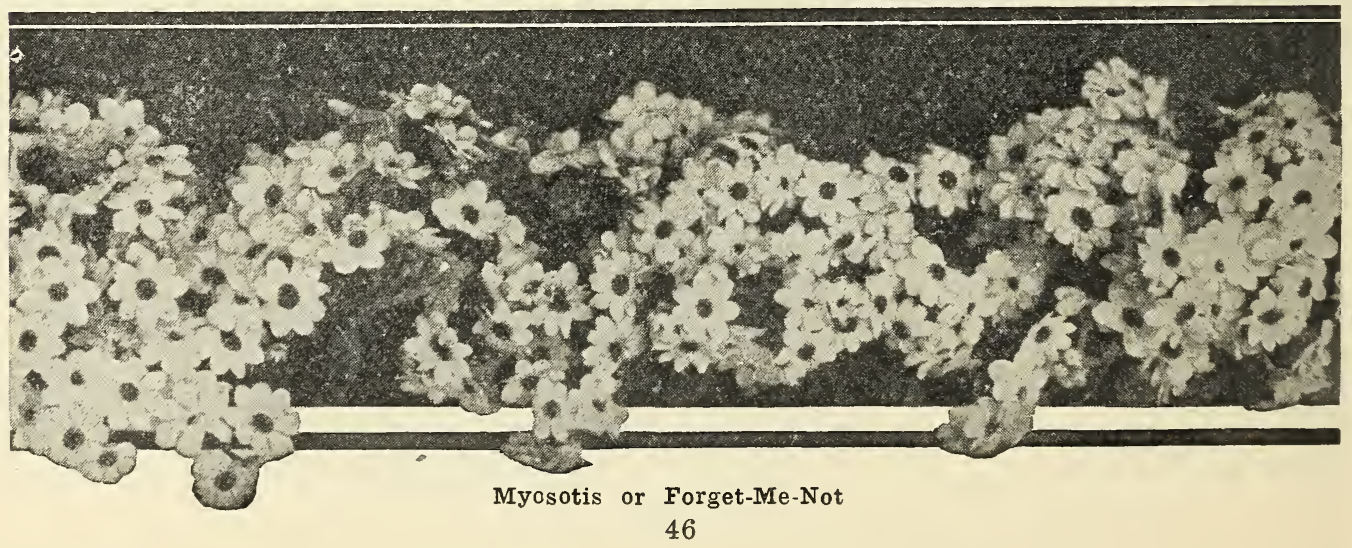


w3950-POPPY, ORIENTAL, Scarlet .

w3951-POPPY, ORIENTAL, Hybrids.

w3961-POPPY, ICELAND (Nudicaule) White.

w3962-POPPY, ICELAND (Nudicaule) Yellow . . . . . . . . . . .

w $\$ 000$-PYRETHRUM Hybridum (Painted Daisy) Pyrethrum are one of the best of the Hardy Perennials to raise for cut-flowers or for sale plants. Our own experience has been we were nerer able to raise enough good plants for our retail trade. Good Prrethrum is one of our specialties and our mixture

contains only the best flowers and colors. Single Mixed Colors. Tr. pkt. 20c w 4211 -RUDBECKIA Purpurea (Giant Purple Cone Flower)

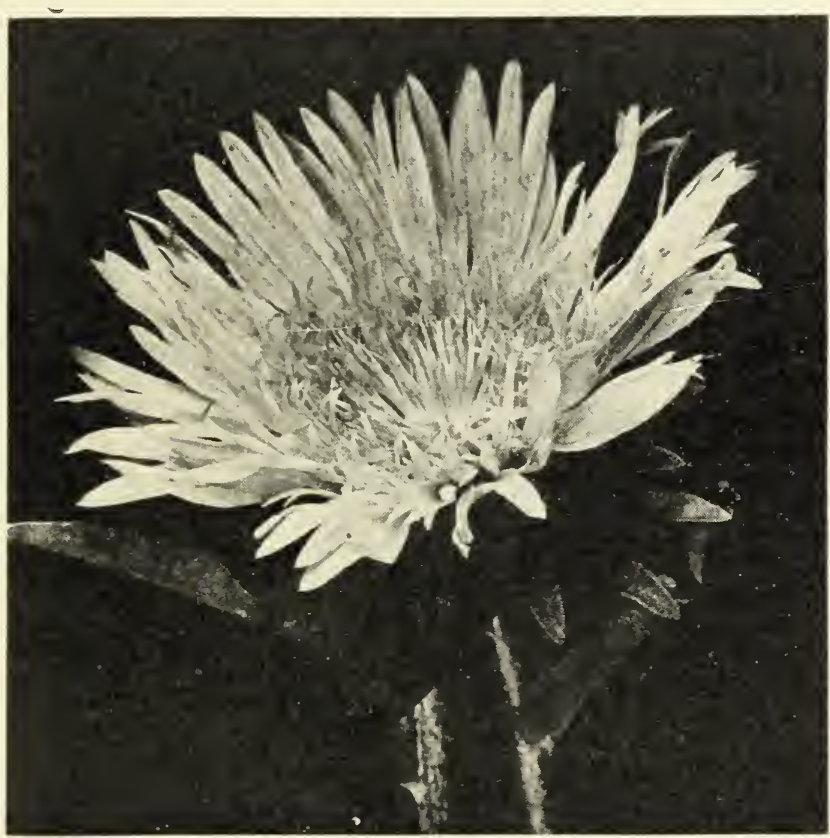

Stokesia, or Stokes' Aster

\section{STOKESIA (Stokes' Aster)}

w6164-C Y A N A, Blue. Stokes Aster is one of the choicest and most distinct of American hardy perennial herbs. The beautiful light. blue flowers are 3 to 4 inches across and profusely borne in July and August on plants 1 to 2 feet high. It prefers a well-drained sandy loam and is exceptionally drought resisting. It blooms at a time of year when good light blue flowers are very scarce and keeps well in water when cut. $1 / 4$ oz. $30 \mathrm{c} ; 0 z$. 1.00 .

\section{SIDALCEA}

w 4682 -ROSY GEM (Pink). This is one of our new perennials and we feel that it will soon become one of the leading border plants. For this reason it will be well to get stocked up with plants.

We have found that Sidalcea seeds only occasionally and this year we have harvested a little seed.

The plant grows about 5 feet tall and during June and July is covered with long, graceful spikes of rosy. pink mallow-like flowers. The shing dark green foliage are very persistent. making it an excellent border plant Tr. pkt. $20 \mathrm{c} ; 1 / 4$ oz. $60 \mathrm{c} ; 0 z . \$ 2.00$.

$w+663$-SCABIOSA Caucasica Perfecta (Blue Bonnet). Very handsome lavender $\mathrm{Oz}^{1 / 4}$ flowers that are wonderful for cutting, always bringing a high price. There is always a demand for plants that exceeds the supply ........... Tr. pkt. $25 \mathrm{c}$ w 4670 -SHASTA DAISY Alaska. Good cut flowers for late summer market and the

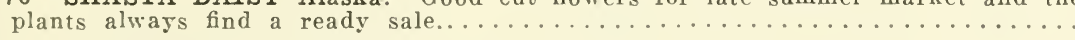
w $\$ 610$-SALVIA Azurea Grandiflora (Hardy Salvia). $\mathrm{O} \mathrm{Oz}$ w6179-STATICE LATIFOLIA (Great Sea-Lavender). A most valuable "Everlast. ing" flower. The large sprays of tiny blue flowers will keep for months after being cut and dried.

SWEET WILLIAM. The improved large-flowering varieties of Sweet Williams make a wonderful display of color in the garden and plants are always in demand. In the spring the flowers sell well for cheap bouquet work. They are so easy to raise that they are profitable to sell to a cheap market.

w6131-WHITE.

w6132-NEWPORT PINK. Olear salmon pink. 


\section{GLADIOLI}

There is no more popular flower to raise for cut-flowers than the good varieties of Gladioli. This list is very carefully selected from the innumerable varieties on the market and represents the most desirable sorts that can be offered at a moderate price. $A l l$ bulbs are at least $11_{2}$ inchs in diameter.

For more complete descriptions, and for descriptions of other especially fine sorts not listed here, see our General Retail Catalog. Te hare a number of second size bulb. (1 in. to $1 \frac{1}{2} \mathrm{in.}$ ) of many of these rarieties on which we will be pleased to quote you special prices on larger lots.

AMERICA. Large suft larender-pink.

Doz. $\quad 10 u$

AUGUSTA. Medium size pure white with blue anther.

3.0

BARON J. FULOT. The most desirable "blue"

$.60 \quad 3.50$

CZAR PETER. Fine wine-red..

EMPRESS OF INDIA. Terp deep relrety crimson.

3.06

6.00

EVELYN KIRTIAND. Tall delicate rosy pink with scarlet blotches on lower petals..

FLORA. A new clear rellow of large size.

$7.0 !$

GLORY OF HOLLAND. Pure creamy white with larender anthers

11.00

GRETCHEN ZANG. Fine clear pink with deep markings. . .

GOLIATH. The largest dark maroon.

GOV. HANLEY. Rich clear cardinal of large size.

10.00

HALLEY. Sparkling pink. The standard extra early................

L'IMIMACUIE. Early pure white of daint? form.

IILY WHITE. A lils-like pure white:

LIEBESFEUER. True scarlet of splendid form. . .

LOVELINESS. Graceful, soft creamp rellow . . . . . . . . . . . . . .

MYRTLE. Earls, delicate rosy-pink.

MRS. FRYER. Glowing flame color

MRS. FRANCIS KING. Immense flowers of rermillion scarlet . . . . . . . . .

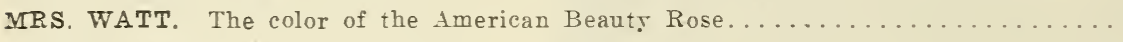

MASTER WEITZE. Dark maroon orerlaid with riolet.

NIAGARA. Soft primrose rellow slightly splashed with crimson..

ORANGE GLORY. FierY orange-red and well rufled .

PANAMA. Large, rich silvery-pink.

MRS. FRANK PENDLETON. Large light pink with red blotches.

PRIDE OF GOSHEN. Shrimp pink suffused with old rose..

PRINCE OF WAIES. Early clear salmon pink. A splendid florists rarietr.

FINK PERFECTION. Soft apple-blossom pink

PRINCEPS. Dazzling scarlet with white throat.

RUFFLD GLORY. (Kunderdii) Cream white with apricot.

SCHWABEN. Large shading flowered canary rellow.

SUNRISE. Early. Immense extra early brilliant salmon

WILIY WIGMAN. Tert light pink with cerise blotch.

WAR. Deep glowing crimson. .

WILBRINK. Extra early light pink sport from Halley.

YOUELI'S FAVCRITE. Immense light lilac-rose shading to sufferino red at edges with cream throat. . . . . . . . . . . . . . . . . . . . . . . . . . .

YELLOW HAMMER. Medium sized yellow with red mark in throat.

SUPERB MIXTURE. This is our best grade of mixture and is very carefully made up including mans of our best sorts . . . . . . . . . . . . . . . . .

WHITE AND IIGHT FLORIST'S MIXTURE. An especially good mixture for the

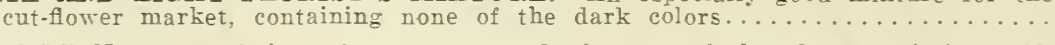
though this is our cheapest mixture. it contains all good bulbs and a good range

PRIMUI.INUS. The Primulinus are a comparatirels new trpe of Gladioli that are rapidl g gaining in popularits, both with the amateurs and florists. The medium sized graceful flowers have a certain gracefulness that is not found in ans other variety of Gladioli, while the unusual colors are largels in the delicate orange shades. 


\section{Insecticides and Fertilizers}

ARSENATE OF LEAD. The find this a much better and cheaper poison than Paris green for use on potatoes, apple trees, etc. It is in paste form and should be applied with water, using 1 ll). to 20 gals. of water. Paste $1-1 b$. can $30 \mathrm{c} ; 121 / 2^{-}$ lb. pails $\$ 1.90$ each; 25-lb. pails $\$ 3.50$; $50-1 b$. can $\$ 6.50 ; 100-1 b$. can $\$ 12.00$. Powder-1-1b. can 35c; 5-1b. cans $\$ 1.25$; $12 \frac{1}{2}$-lb. pails $\$ 2.75 ; 25-1 b$. pails $\$ 5.25$.

TOBACCO DUST. Tobaceo dust is an excellent material for keeping bugs off cucumber, melon and squash rines. The dust should be applied when the leares are wet so that it will adhere to them. It should be used in liberal quantities. For fumigating greenhouses the tobacco dust we sell is most excellent. It burns evenly and will light without the use of kerosene. 5 lbs. will fumigate a house $20 \times 100$ feet. 5-1b. package 50c; 10-1bs. 75c: $50 \mathrm{lbs}$. or more at $6 \mathrm{c}$ per $\mathrm{lb}$.

FORMALIN (Formaldehyde, 40 per cent). A valuable disinfectant for destroring germs that cause diseases in plants. It is ver effective when used to destroy smut germs in oats and seab on potatoes. To treat oats use 1 pint formalin to 50 gallons of water and soak ten minutes. For potatoes use 1 pint to 30 gallons and soak two lours. Pint 50c; quart $75 \mathrm{c}$; gallon \$2.10. Cannot be sent by parcel post.

SULPHO-TOBACCO SOAP. For killing aphis or lice on roses and other plants we have found nothing so effective and convenient as Sulpho-Tobaceo Soap. Directions for use are printed on the cover of each cake. A 3-oz. cake makes $11 \% 2$ gallons and an 8-oz. cake $t$ gallons of the solution. 3-oz. cakes $10 \mathrm{c} ; 8-0 z$. cakes 20c.

WHITE HELLEBORE. The best remedr for currant and cabbage worms. Apply dry or in water. Per lb. 65c.
BUG DEATH. A well-known insecticide. It is a fine powder and may be applied with a duster or in water as preferred. 1-1b. package 25c each; 5-1b. package $75 \mathrm{c}$ each; $12 \frac{1}{2}$-lb. kegs $\$ 1.75$ each.

LAMBERT'S DEATH TO IICE. This is the most effective remedy for killing lice on poultry we have found. Death to lice is a powder and is easily applied to the fowls by dusting it through the feathers. It kills the lice within a few minutes after applying. 15-ounce cans 25c. Full directions for use are printed on each can.

NITRATE OF SODA. This is the most soluble and quickly arailable form of nitrogen or "ammonia." It is of great benefit in foreing a strong luxuriant growtl in plants. It is especially valuaile for cabbage, cauliflower, beets, carrots, celery, spinach, onions, tomatoes, potatoes and similiar crops, as well as for grass and grain. It can be adrantageously used as a top dressing after plants are up. It is immediately arailable to the plants when applied.

Gardeners should always have some nitrate of soda on hand and use it whenever they want to promote a quick, strong growth in plants. A little nitrate dissolved in water at the rate of about a tablespoonful ( 1 oz.) to 2 gallons of water will stimulate a rapid growth either when applied to plants in frames, greenhouses or the open ground. If your plants don't grow well, try a little nitrate on them-but don't use too much. 10 lbs. 65c; 50 lbs. \$2.75; 100 lbs. \$4.75; bag (200 lbs.) $\$ 9.00$. Prices subject to change.

BONE MEAL. One of the best fertlizers for garden crops. The meal we offer is finely ground raw bone containing $41 / 2$ per cent. Ammonia or Nitrogen and 50 per cent. phosphate of lime equiralent to 24 per cent phosphoric acid. $100 \mathrm{lbs}$. $\$ 4.00$; bag, 167 lbs. $\$ 6.00$.

\section{Protect Cabbage Plants from Maggots}

The most effertive way to keep early cabbage and cauliflower free from maggots at the roots appears to be the tar-paper pads or dises, which have been used for some rears on Long Island with excellent results.

The eggs which produce the maggots are laid on the stems of the plants by a little fly aloout the size of the common house fly. IThen the eggs hatch the roung maggots rawl down to the roots and there eat the stem until the plant dies, or is badly injured.

It has been found that small dises or pads made of tarred paper placed around the stem of the plant when set out prevent the flo from laving the eggs on the stem and thus save the plant from injury.
The New York State Agricultural Ex periment Station issued a bulletin some time ago referring to experiments made with different methods of protecting plants from the maggots. According to this report the tar-paper pads proved ly far the most effective method of treatment.

How to apply the tar pads. By means of a slit the pard is slipped around the stem of the plant, the center of the pad heing also slit cross-wars bends rlown and fits closely around the stem.

Apply the pads the same day the plants are set out. If this work is delaved for a few days it gives the flies a chance to deposit their eggs.

Price of Tar-Paper Pads: 100, 40c; 1000 . $\$ 2.25 ; 5000$ or more at $\$ 2.00$ per 1000 . 


\section{Harris' Seeds for Market Growers}

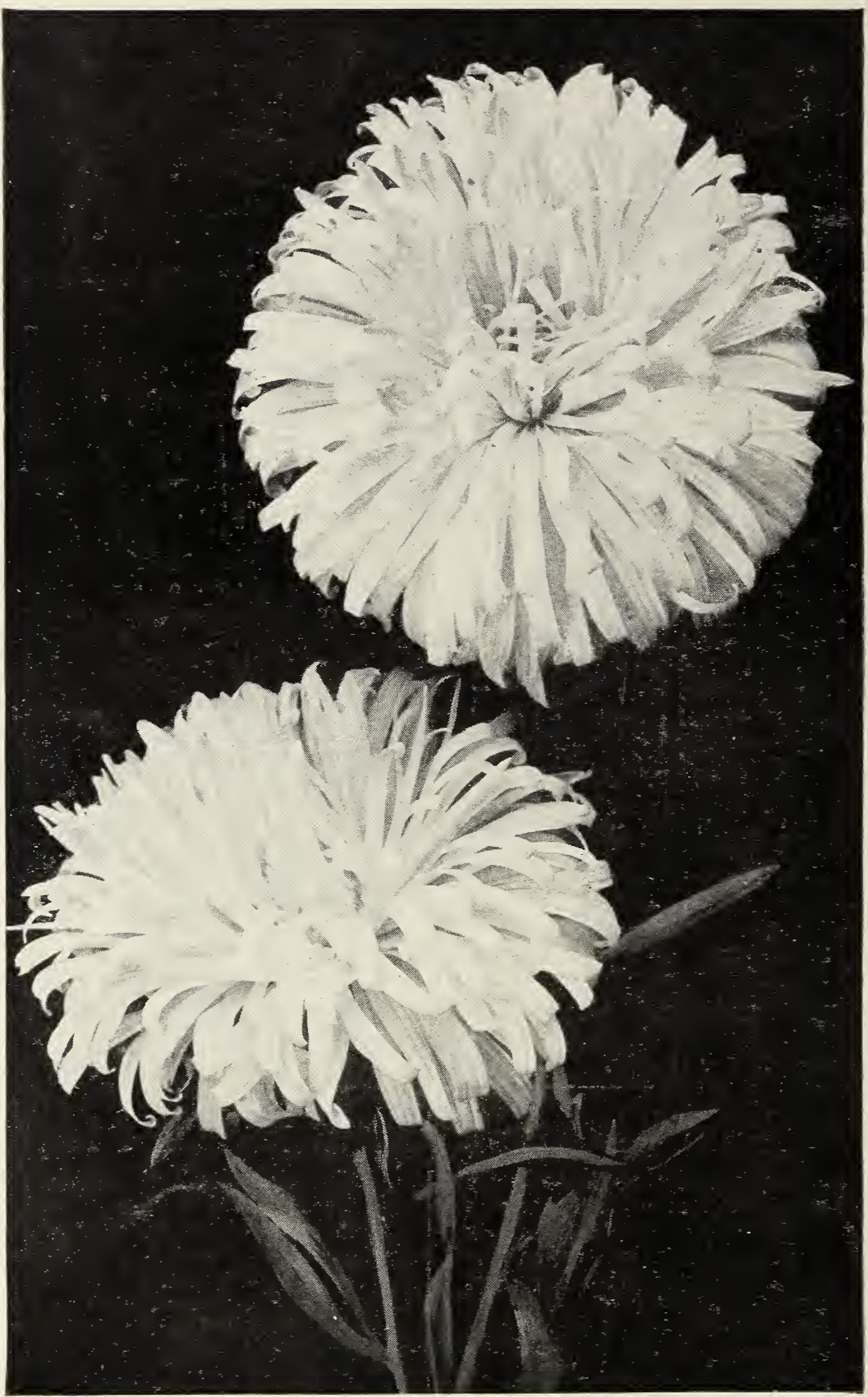

OSTRICH FEATHER ASTER

A new strain with large flowers and very long stems. See page 36

JOSEPH HARRIS CO., Seed Growers Moreton Farm COLI)WATER, N. Y. 